Canadian Science Publishing

Canadian Journal of Earth Sciences Revue canadienne des sciences de la Terre

Chronostratigraphy of the Hottah terrane and Great Bear magmatic zone of Wopmay orogen, Canada, and exploration of a terrane translation model

\begin{tabular}{|r|l|}
\hline Journal: & Canadian Journal of Earth Sciences \\
\hline Manuscript ID & cjes-2015-0026.R2 \\
\hline Manuscript Type: & Article \\
\hline Date Submitted by the Author: & 13 -Jul-2015 \\
\hline Complete List of Authors: & $\begin{array}{l}\text { Ootes, Luke; Northwest Territories Geological Survey, } \\
\text { Davis, William; Geological Survey of Canada, } \\
\text { Jackson, Valerie; Northwest Territories Geological Survey, } \\
\text { van Breemen, Otto; Geological Survey of Canada, }\end{array}$ \\
\hline Keyword: & $\begin{array}{l}\text { Hottah terrane, Great Bear magmatic zone, CA-ID-TIMS U-Pb zircon, } \\
\text { terrane translation, rifting arc }\end{array}$ \\
\hline \multicolumn{2}{|c}{} \\
\hline
\end{tabular}

\title{
SCHOLARONE"
}

Manuscripts 


\section{Chronostratigraphy of the Hottah terrane and Great Bear magmatic zone of Wopmay orogen, Canada, and exploration of a terrane translation model}

4 *Corresponding Author:

5 Luke Ootes

Government of the Northwest Territories, Northwest Territories Geological Survey, Box 1320, Yellowknife, NT X1A 2L9

8 (867) 765-6617

$9 \quad$ Luke_ootes@gov.nt.ca

William J. Davis

12 Geological Survey of Canada, 601 Booth Street, Ottawa, ON K1A 0E8

13 (613) 943-8780

14 bidavis@nrcan.gc.ca

Valerie Jackson

17 Government of the Northwest Territories, Northwest Territories Geological Survey, Box 1320,

18 Yellowknife, NT X1A 2L9

19 (867) 765-6608

20 Valerie_jackson@gov.nt.ca

Otto van Breemen

Geological Survey of Canada, 601 Booth Street, Ottawa, ON K1A 0E8

Otto.vanbreemen@nrcan.gc.ca

vanotto@rogers.com

(1)

2




\section{Abstract} Canadian Shield, and a critical component for understanding the evolution of the Wopmay orogen. Thirteen new high-precision U-Pb zircon crystallization ages are presented and support

5 field observations of a volcano-plutonic continuum from Hottah terrane through to the end of the Great Bear magmatism; from >1950 Ma to $1850 \mathrm{Ma}$. The new crystallization ages, new geochemical data, and newly published detrital zircon $\mathrm{U}-\mathrm{Pb}$ data, are used to challenge hitherto accepted models for the evolution of the Hottah terrane as an exotic arc and micro-continent that arrived over a west-dipping subduction zone and collided with the Slave craton at ca. $1.88 \mathrm{Ga}$. While the Hottah terrane does have a tectonic history that is distinct from that of the

11 neighbouring Slave craton, it shares a temporal history with a number of domains to the south 12 and east, domains that were tied to the Slave craton by ca. $1.97 \mathrm{Ga}$. It is interpreted herein that 13 Hottah terrane began to the south of its current position and evolved in an active margin over an

14 always east-dipping subduction system that began prior to ca. $2.0 \mathrm{Ga}$ and continued to ca. 1.85

$15 \mathrm{Ga}$, and underwent tectonic switching and migration.

The stratigraphy of the ca. 1913 to 1900 Ma Hottah plutonic complex and Bell Island Bay

17 Group comprises a subaerial rifting arc sequence, followed by basinal opening that is represented

18 by marginal marine quartz arenite and overlying ca. 1893 Ma pillowed basalt flows and lesser

19 rhyodacites. We interpret this stratigraphy to record Hottah terrane rifting off its parental arc

20 crust, in essence the birth to the new Hottah terrane. This model is similar to rapidly rifting arcs

21 in active margins, for example modern Baja California. These rifts generally occur at the

22 transition between subduction zones (e.g., Cocos-Rivera plates) and transtensional shear zones

23 (e.g., San Andreas fault) and we suggest that extension driven transtensional shearing, or more

24 simply terrane translation, was responsible for the evolution of Bell Island Bay Group

25 stratigraphy and that it transported this newly born Hottah terrane laterally (northward in modern

26 coordinates), arriving adjacent to the Slave craton at ca. $1.88 \mathrm{Ga}$. Renewed east-dipping

27 subduction led to the Great Bear arc flare-up at ca. $1876 \mathrm{Ma}$, continuing to ca. $1869 \mathrm{Ma}$. This

28 was followed by voluminous Great Bear plutonism until ca. $1855 \mathrm{Ma}$. The model implicates that

29 it was the westerly Nahanni terrane and its subducting oceanic crust that collided with this active 30 margin, shutting down the $>120$ million year old, east-dipping subduction system. 


\section{$1 \quad$ Keywords}

2 Hottah terrane, Great Bear magmatic zone, CA-ID-TIMS U-Pb zircon, terrane translation, 3 rifting arc 


\section{Introduction}

In September 2012, NASA's Curiosity rover discovered an outcrop of alluvial derived conglomerate in Gale Crater, Mars and was named Hottah, after Hottah Lake, Northwest Territories, Canada (Williams et al. 2013; http://mars.jpl.nasa.gov/msl/). Ironically, the details of some of the remote bedrock exposures around Hottah Lake, here on Earth, remain enigmatic. The Wopmay orogen, the westernmost exposed bedrock of the Canadian Shield, is a middle Paleoproterozoic orogenic belt that was one of the first Precambrian domains to have been attributed to plate tectonic processes (Fraser et al. 1972; Hoffman 1973, 1980, 1988, 2012). The Hottah terrane figures prominently in proposed evolutionary models for the Wopmay orogen and it was recognized early on that understanding the Hottah terrane was key to deciphering the Wopmay orogen (Hoffman 1973; McGlynn 1976, 1979; Hoffman and McGlynn 1977; Hildebrand 1981). Forty years later, while new evidence continues to accumulate regarding the development of Wopmay orogen (e.g., Hoffman et al. 2011; Jackson et al. 2013), details regarding the evolution of Hottah terrane remain sparse (Bowring 1984). Presented herein are new high-precision U-Pb zircon ages from the Hottah terrane and select volcanic horizons in the central Great Bear magmatic zone, complemented with trace-element and Nd-isotope data. The new and previously available data allow the construction of a stratigraphic framework that can be used to evaluate previous tectonic models. We also use these data to propose a transtensional shear model (terrane translation; Umhoefer 2011).

\section{Geological Setting}

Framework elements of the Wopmay orogen include the Coronation margin and its cratonic and reworked Archean Slave craton basement in the east, and the Great Bear magmatic zone and Hottah terrane in the west (Figs. 1-2; Fraser et al. 1972; Badham 1973; Hoffman 1973, 1980, 1984, 1988; Hoffman and McGlynn 1977; Hoffman et al. 1976; St-Onge and King 1986, 1987; Villeneuve et al. 1991, 1993; Aspler et al. 2003; Cook and Erdmer 2005; Jackson 2008; Hildebrand et al. 1987a, b; 2010a, b; Jackson and Ootes 2012; Jackson et al. 2013; Ootes et al. 2013). The Coronation margin includes Archean crust, the ca. 2.014 Ga Melville Group rift to drift sequence, $1.97 \mathrm{Ga}$ Epworth Group passive margin sedimentary rocks, and ca. $1.88 \mathrm{Ga}$ Recluse Group foredeep sedimentary rocks preserved in the east-verging Asiak thrust-fold belt, as well as correlatives preserved as supracrustal, gneissic and intrusive rocks in the metamorphic 
1 internal zone (Hoffman 1973, 1980, 1984; St-Onge and King 1986, 1987; Bowring and

2 Grotzinger 1992; Hoffman et al. 2011; Jackson et al. 2013). The Wopmay fault zone is a north-

3 south striking crustal-scale fault that delimits the western extent of exposed Archean rocks in the

4 Wopmay orogen (Figs. 1-2; St-Onge et al. 1983; King 1987; Bowring and Podosek 1989; Housh

5 et al. 1989; Jackson 2008; Jackson et al. 2006, 2013; Spratt et al. 2009; Jackson and Ootes 2012:

6 also called medial zone by Hildebrand et al. 1991, 2010a). West of Wopmay fault zone are the

7 remnants of the $>1.9 \mathrm{Ga}$ Hottah terrane, which was extensively overprinted by ca. 1.875 to 1.85

8 Ga Great Bear magmatism (e.g., Fraser et al. 1972; Badham 1973; Bowring 1984; Gandhi et al.

9 2001; Hildebrand et al. 2010b). Northeast-striking brittle faults dextrally offset all units and are

10 transected by the ca. 1740 Ma Cleaver dykes (Irvine et al. 2004; Hayward and Corriveau 2014).

11 The northern Wopmay orogen is covered by the Paleo- to Mesoproterozoic Coppermine

12 Homocline (Fig. 2; Kerans et al. 1981). The Hottah terrane and Great Bear magmatic zone are

13 covered in the west by Cambro-Ordovician and Cretaceous-Tertiary rocks of the Phanerozoic

14 platform (Figs. 1-2). Geophysical studies have shown that the Hottah terrane and Great Bear

15 magmatic zone have properties distinct from those of the Slave craton and overlying Coronation

16 margin to the east, and the Fort Simpson magnetic high and enigmatic Nahanni terrane to the

17 west (Fig. 1; Fraser et al. 1972; Hoffman 1988; Cook et al. 1999; Aspler et al. 2003; Cook and

18 Erdmer 2005; Wu et al. 2005; Spratt et al. 2009; Oueity and Clowes 2010; Ootes et al. 2013;

19 Hayward and Corriveau 2014). Much of what has been 'imaged' in these experiments is covered

20 by the Phanerozoic platform and directly assessing the underlying bedrock components,

21 especially of the Hottah terrane, is not currently possible. This lack of exposure introduces

22 uncertainty in the regional interpretation, for example a $100 \mathrm{~km}$ wide magnetic low under the

23 Phanerozoic platform, between the Great Bear magmatic zone and Fort Simpson terrane, is

24 interpreted to be Hottah terrane (Fig. 1; Aspler et al. 2003). As there are no sub-Phanerozoic

25 samples from this area, it is difficult to confirm what rocks are causing this uniformly low

26 magnetic signature. In fact, the actual Hottah bedrock exposures that are examined in this study

27 (Figs. 1 and 2) are commonly weakly to strongly magnetic and generally have mid- to high-

28 magnetic signatures on regional surveys.

29

30 Hottah terrane and Great Bear magmatic zone 
On the basis of its bedrock and geochemical characteristics, the Hottah terrane can be compartmentalized into at least five components. 1) A cryptic ca. 2.6 to 1.97 Ga source domain, indicated from U-Pb zircon ages in sedimentary rocks (Bowring 1984; Davis et al. submitted) and radiogenic tracer isotope studies on younger magmatic rocks $(\mathrm{Nd}, \mathrm{Pb}$; Bowring and Podosek 1989; Housh et al. 1989). 2) The ca. 1950 Ma Holly Lake metamorphic complex comprises the oldest recognized bedrock exposures west of the Wopmay fault zone. It consists of pelites and metabasalt, and is preserved at Great Bear Lake, Leith ridge, and along the Zebulon River on the east side of Hottah Lake (Fig. 2 and 4A; Hildebrand 1984; Hildebrand et al. 1983, 1984; Bowring 1984; Jackson and Ootes 2012; Davis et al. submitted). 3) Circa 1930 to $1910 \mathrm{Ma}$ plutonic rocks that generally have penetrative deformation fabrics (Fig. 4B; McGlynn 1979;

11 Hildebrand 1984, 1985; Hildebrand et al. 1983, 1984; Bowring 1984), referred to as Hottah 12 plutonic complex. 4) The Bell Island Bay Group volcanic and sedimentary rocks that were 13 erupted and deposited on top of the older and deformed Holly Lake metamorphic complex and 14 Hottah plutonic complex rocks (Fig. 4C-E; Hildebrand et al. 1983, 1984; Reichenbach 1991). 15 These are best preserved at Bell Island, the east shore of Hottah Lake, and at Beaverlodge Lake 16 (Fig. 2). The Bell Island Bay Group consists of the basal Beaverlodge Lake sandstone (Fig. 4C), 17 which is overlain by the $1898.4+7.2 /-6.3$ Ma Zebulon Formation subaerial volcanic rocks (Fig. 18 4D; Reichenbach 1991). Hildebrand (1984) assigned the marginal marine quartz arenite and 19 siltstone of the Conjuror Bay Formation, and overlying Bloom Basalts, as the base of the Great 20 Bear magmatic zone. Reichenbach (1991), however correlated the Bloom Basalts with the ca. 211900 Ma Grant Subgroup and Akaitcho Group of Easton (1980, 1981a,b) and assigned the 22 Conjuror Bay Formation and Bell Island Bay Group as the upper part of the Bell Island Bay 23 Group. 5) The $<1885$ and $>1875$ Ma Treasure Lake Group metasedimentary rocks are considered 24 the youngest component of the Hottah terrane (Gandhi and van Breemen 2005). The Treasure 25 Lake Group type section is in the southern Great Bear magmatic zone with another exposure 26 documented at DeVries Lake (Fig. 2A; Bennett and Rivers 2006b; Jackson 2008). Two models have been proposed for the evolution of Hottah terrane (Fig. 3). The most 29 continent with an overriding ca. $1.9 \mathrm{Ga}$ volcanic arc. This arc developed over west-dipping 30 subduction of the Coronation ocean crust that underwent a rift to drift transition at ca. 2.01 Ga 31 (Hoffman et al. 2011). Coronation ocean subduction was terminated by the arrival and collision 
1 of this exotic micro-continent and arc with the western Archean Slave craton and the overlying

2 Coronation margin at ca. 1.88 Ga (Fig. 3A; Hildebrand 1981; Bowring and Podosek 1989;

3 Bowring and Grotzinger 1992; Hildebrand et al. 2010a; Hoffman et al. 2011; Hoffman 2012).

4 The time-frame of the transition from Coronation passive to active margin sedimentation (ca.

51.97 to $1.88 \mathrm{Ga}$ ) is consistent with modern ocean opening and closing, and micro-continent -

6 continent collision is the attributed driver for this transition (Hoffman 2012; Hoffman et al.

7 2011). The second and less favourable model suggests that Hottah terrane evolved as an arc that

8 developed on attenuated crust of the Slave craton and these were separated by a back-arc basin

9 (Fig. 3B; Reichenbach, 1991; Bowring and Grotzinger 1992). This model was consistent with

10 bedrock mapping and petrological studies within the metamorphic internal zone (east of the

11 Wopmay fault zone) and the results were interpreted to record opening and closing of an ensialic

12 back-arc basin between 1.89 and 1.88 Ga (Easton 1980, 1981a; St-Onge and King 1986, 1987;

13 Lalonde 1989).

14 The ca. 1875 to 1850 Ma Great Bear magmatic zone igneous rocks (Fig. 4F-G) were

15 erupted onto and intruded into the older Hottah terrane stratigraphy and dominate the bedrock

16 exposures west of the Wopmay fault zone (Figs. 1 and 2; Bowring 1984; Gandhi et al. 2001;

17 Hildebrand et al. 2010b). Screens of volcanic rocks that range from andesite to trachyandesite to

18 rhyolite are preserved in a sea of younger plutons that only rarely contain penetrative

19 deformation fabrics. These plutonic rocks range in composition from gabbro to syenogranite,

20 although they are predominantly monzonitic to monzogranitic (e.g., Fraser et al. 1972; Badham

21 1973; Hildebrand 1984; Hildebrand et al. 1987, 2010b; Gandhi 1994; Gandhi et al. 2001; Ootes

22 et al. 2013).

23 The Great Bear magmatic zone is considered to have been an Andean-like magmatic arc

24 resultant from oblique east-dipping subduction under the Hottah terrane and Slave margin (Fig.

25 3A; Badham 1973; Hildebrand 1981; Hildebrand et al. 1987a, 2010a, b). Geophysical

26 experiments support this and show that east-dipping, subducted Paleoproterozoic oceanic crust is

27 now frozen beneath the Great Bear magmatic zone and the western Slave craton (Fig. 1B; Cook

28 et al. 1999; Cook and Erdmer 2005; Wu et al. 2005; Oueity and Clowes 2010). The geophysical

29 features intimate that this oceanic crust was rooted in the enigmatic Nahanni terrane to the west

30 (Fig. 1). 
Bedrock mapping and $\mathrm{U}-\mathrm{Pb}$ zircon geochronology of Archean basement in the metamorphic internal zone of the Wopmay orogen and bedrock mapping in the vicinity of Hottah

Lake has raised a number of questions about the previously ascribed relationship of the Slave craton and Hottah terrane (Jackson and Ootes 2012; Jackson et al. 2013). For this study we collected and dated key volcanic and plutonic units within the central area of the Wopmay orogen, mostly between $64^{\circ} \mathrm{N}$ and $65^{\circ} \mathrm{N}$ (Fig. 2), in order to help resolve stratigraphic challenges that arose during bedrock mapping, and to assess the temporal and petrological evolution of the Hottah terrane - Great Bear magmatic zone transition. The new and previously published data (Hildebrand et al. 1983; Bowring 1984; Reichenbach 1991; Gandhi et al. 2001; Bennett and Rivers 2006a) allow the construction of a time-constrained stratigraphic column that records the transition from Hottah terrane to Great Bear magmatic zone tectonics. Such constraints are needed to further evaluate the proposed models for the evolution of Wopmay orogen.

\section{U-Pb Zircon Geochronology \& Lithogeochemistry}

$15 \mathrm{U}-\mathrm{Pb}$ zircon geochronology was completed at the Geological Survey of Canada, Ottawa,

16 Ontario, Canada. Zircon separates were analyzed by chemical abrasion isotope dilution thermal

17 ionization mass spectrometry (CA-ID-TIMS; Mattinson 2005). The zircon separates from one

18 sample (09vj171) were mechanically abraded prior to analysis (Krogh 1982). Those from sample

$1909 \mathrm{vj} 148 \mathrm{c}$ were of poor quality and therefore zircons from this sample were analyzed using the

20 sensitive high resolution ion microprobe (SHRIMP II; Stern 1997). Sample locations are

21 identified on Figure 2, analytical techniques are in the Appendix, and results are tabulated in

22 Tables 1 and 2 and presented in Figure 5.

23 To complement the dating and evaluate the petrologic evolution of the Hottah terrane and

24 Great Bear magmatic zone rocks, a number of samples were selected for major and trace-element

25 geochemistry and Sm-Nd isotope geochemistry (Tables 3, A1, and A2). Analytical techniques

26 are in Appendix I. More in-depth bedrock descriptions are available in the online Supplementary 27 data.

29 Hottah Plutonic Complex

30 Porphyritic Granite (Hg) 
Coarse-grained K-feldspar porphyritic granite with partially chloritized biotite was

2 collected from Beaverlodge Lake ridge ('Hg' on Fig. 2B). This granite is similar to other

3 'syenogranites' throughout this area and previous investigators assigned it to the Hottah terrane

4 (Hildebrand and Roots 1985). Locally, the granite is unconformably overlain by coarse pebble

5 conglomerate of the Conjuror Bay Formation, or rhyolite flows of the Zebulon Formation, both

6 of the Bell Island Bay Group. Five single grains were analyzed by CA-ID-TIMS, yielding four

7 near concordant and one $2.2 \%$ discordant analyses (Table 1 ). $\mathrm{A}{ }^{207} \mathrm{~Pb} /{ }^{206} \mathrm{~Pb}$ weighted mean of the

8 four most concordant grains provides a date of $1930 \pm 1.0 \mathrm{Ma}$ and a best-fit discordia line

9 through the data provides an indistinguishable upper intercept age of 1930.6 $\pm 1.3 \mathrm{Ma}$, with a

10 lower intercept of $276 \pm 160 \mathrm{Ma}(\mathrm{MSWD}=0.71$; Fig. 5A; Table 1). The $1930.6 \pm 1.3 \mathrm{Ma}$ upper

11 intercept age is interpreted as the timing of magma crystallization.

Hypabyssal Porphyry (Hp)

$14 \quad$ Feldspar and quartz phyric porphyry was sampled on Beaverlodge ridge ('Hp' on Figs.

$152 \mathrm{~B}$ and $4 \mathrm{E}$ ). This porphyry has a fine-grained groundmass and is interpreted as hypabyssal in

16 nature. The porphyry is spatially associated with the porphyritic granite discussed above

17 (09109078a); however, no contacts are exposed. The porphyry is unconformably overlain by two

18 formations of the Bell Island Bay Group. At the lower unconformity hematized, fragmental

19 rhyolite flows and volcanic breccia of the Zebulon Formation overlie the porphyry. The Conjuror

20 Bay Formation quartz arenite overlies and cuts into both the Zebulon Formation volcanic rocks

21 and the older porphyry (Fig. 4E; Shakotko et al. 2012). The porphyry is moderately to

22 extensively altered, with abundant hematite in the groundmass, minor magnetite replacement of

23 some mafic crystals, and hematite-chlorite veining. Hildebrand and Roots (1985) assigned this

24 porphyry to the Great Bear magmatic zone as the unconformable nature of the overlying units

25 (Fig. 4E) was not yet recognized.

26 A least altered sample of the porphyry yielded pristine igneous zircon, of which five

27 grains were analyzed by CA-ID-TIMS (Table 1). Three grains yield concordant dates at $1931 \mathrm{Ma}$

28 whereas two others are very slightly discordant. A weighted mean of the five analyses indicates a

$29{ }^{207} \mathrm{~Pb} /{ }^{206} \mathrm{~Pb}$ crystallization age of $1930.5 \pm 1.1 \mathrm{Ma}(\mathrm{MSWD}=0.95$; Fig. 5B; Table 1$)$. This

30 crystallization age is indistinguishable from that of the porphyritic granite and these are 
1 collectively assigned as part of the Hottah plutonic complex. Samarium-Neodymium isotopic

2 data indicate this quartz-plagioclase porphyry has an $\varepsilon \mathrm{Nd}^{1930}$ value of-1.5 (Fig. 6; Table 3)

$4 \quad$ Strongly deformed granodiorite (ZR)

5 A strongly deformed to mylonitic granodiorite with abundant biotite-schlieren represents

6 the oldest plutonic phase recognized south of the Zebulon River ('ZR' on Fig. 2A). This is the

7 most pervasively deformed rock we have observed in the study area west of Archean mylonite

8 within the Wopmay fault zone. The deformed granodiorite occupies a $100 \times 100 \mathrm{~m}$ area, is

9 overlain by one small outcrop of quartzite, and is intruded by hornblende-biotite granodiorite,

10 which is also deformed, albeit much more weakly (sample \#11lo4155 below). Zircons from the

11 granodiorite are clear and colourless prismatic grains. Five of six CA-ID-TIMS analyses yield a

12 weighted mean ${ }^{207} \mathrm{~Pb} /{ }^{206} \mathrm{~Pb}$ age of $1927.9 \pm 0.9 \mathrm{Ma}(\mathrm{MSWD}=0.68$, Fig. 5C; Table 1),

13 interpreted as the crystallization age of the rock. This plutonic rock is slightly younger, albeit

14 much more strongly deformed, than the porphyritic granite and hypabyssal porphyry at

15 Beaverlodge Lake. The granodiorite has an $\varepsilon \mathrm{Nd}^{1930}$ value of -1.6 (Fig. 6a; Table 3).

\section{Foliated Tonalite (Ht)}

On an island in the east-central Hottah Lake, a tonalite ('Ht' on Fig. 2B) is intruded by

19 diorite, quartz diorite, and equigranular granite. The rocks contain an east-southeast striking,

20 steeply south-dipping foliation and have undergone moderate secondary alteration, including

21 epidote replacement of hornblende and localized magnetite-bearing veins. Mafic dykes, likely

22 Fishtrap Lake gabbros (Reichenbach 1991), cross-cut the more leucocratic plutonic phases.

23 Zircons from an unaltered tonalite, representing the oldest phase on the island, consist of

24 euheral prismatic grains or grain fragments, many of which are heavily fractured. Six single

25 grains were analyzed by CA-ID-TIMS, yielding a weighted mean ${ }^{207} \mathrm{~Pb} /{ }^{206} \mathrm{~Pb}$ age of $1912.9 \pm 0.7$

$26 \mathrm{Ma}(\mathrm{MSWD}=0.35$; Fig. 5D; Table 1), interpreted as the crystallization age of the rock. The

27 tonalite has an $\varepsilon \mathrm{Nd}^{1913}$ value of +1.8 (Fig. 6; Table 3). 
On the southwest end of Beaverlodge ridge, the Zebulon and Conjuror Bay formations unconformably overlie the Hottah plutonic complex (Fig. 2B). The Zebulon Formation includes rhyolitic and basaltic volcanic rocks and a distinctive flow of variably hematized spherulitic rhyolite, with spherules up to $5 \mathrm{~cm}$ in diameter and quartz-filled lithophysae, was collected for

$5 \mathrm{U}-\mathrm{Pb}$ zircon dating ('Zr' on Fig. 2B; Fig. 4C). This flow appears identical to a similar flow on on the east side of Hottah Lake, about $30 \mathrm{~km}$ to the north.

The sample yielded euhedral prismatic zircon. Four single zircon analyses by CA-ID-

$9=0.88$; Fig. 5E; Table 1). A sample of Zebulon basalt from the east side of Hottah Lake has $\varepsilon \mathrm{Nd}^{1906}=+2.1$, and the Zebulon Formation rhyolite dated above has an $\varepsilon \mathrm{Nd}^{1906}$ value of +0.8

11 (Fig. 6; Table 3).

\section{Bloom Rhyodacite (Br)}

One of the islands in central Hottah Lake consists entirely of rhyodacite flows, interpreted to overlie the mafic volcanic dominated Bloom Basalt pile of the Bell Island Bay Group (Fig. 2B; Reichenbach, 1991). A sample of a fragmental rhyodacite flow ('Br' on Fig. 2)

17 was carefully selected in order to test the timing of this mafic volcanism. The rhyodacite sample yielded clear, colourless euhedral prismatic zircon. Four single grain CA-ID-TIMS analyses yielded concordant to reversely discordant data with overlapping ${ }^{207} \mathrm{~Pb} /{ }^{206} \mathrm{~Pb}$ ages giving a

20 weighted mean of $1895 \pm 2.3 \mathrm{Ma}(\mathrm{MSWD}=1.3$; Fig. 5F; Table 1). This is interpreted as the age

21 of the rhyodacite and is a minimum age for the Bloom Basalts. The Bloom rhyodacite sample

22 has an $\varepsilon \mathrm{Nd}^{1895}$ value of -1.8 and a Bloom Basalt sample has an $\varepsilon \mathrm{Nd}^{1895}$ value of +2.3 (Fig. 6;

23 Table 3).

\section{Grant Subgroup}

\section{Grant Rhyodacite (GL)}

Reichenbach (1991) correlated the Bloom Basalts to the Grant Subgroup (Easton, 1981b) that occur east of Wopmay fault zone. A sample of rhyodacite from within the Grant pillowed basalts, north of Grant Lake ('GL' on Fig. 2) was collected for U-Pb zircon dating. The rhyodacite yielded clear, colourless equidimensional to stubby zircons, devoid of fractures or mineral inclusions. Five mechanically-abraded single zircon grains were analyzed by ID-TIMS 
1 and yielded concordant to $0.7 \%$ discordant data points that are aligned with upper and lower

2 intercept ages of $1895 \mathrm{Ma}$ and $549 \mathrm{Ma}$, respectively. A weighted mean ${ }^{207} \mathrm{~Pb} /{ }^{206} \mathrm{~Pb}$ age of 1892.9

$3 \pm 1.5 \mathrm{Ma}$ (MSWD $=0.29$; Fig. $5 \mathrm{G}$; Table 1 ) is interpreted as the age of crystallization of the

4 rhyodacite and the interbedded pillowed basalts. Two samples from the Grant Subgroup basalts,

5 one from the rhyolite sample location north of Grant Lake and the other from the north end of

6 Rebesca Lake $\sim 40 \mathrm{~km}$ south to the south (Fig. 2), have $\varepsilon \mathrm{Nd}^{1893}$ values of +1.7 and +1.7 (Fig. 6 ;

7 Table 3).

\section{LaBine Group}

10 Rhyolitic Ash tuff (DL)

At DeVries Lake ('DL' on Fig. 2A) strongly deformed and altered Treasure Lake Group metasedimentary rocks are overlain by volcanic rocks of the Great Bear magmatic zone (Gandhi 1994; Jackson 2008; Ootes et al. 2010). The volcanic rocks, which are preserved in a few small

14 islands in the southern part of the lake, are variably altered; lithic fragments are altered to either magnetite, actinolite, or biotite. These volcanic rocks contain a weak foliation, defined by the flattened fragments. Rare, fine-grained felsic ash-tuff beds were observed on the east side of one

17 of the islands and sampled to determine the timing of volcanism. Zircon separates form clear, colourless, well-terminated euhedral prisms 150 to 200 um in length. Three single-grain analyses were undertaken by CA-ID-TIMS and yield concordant results with a weighted mean ${ }^{207} \mathrm{~Pb} /{ }^{206} \mathrm{~Pb}$ age of $1876.4 \pm 2.4 \mathrm{Ma}(\mathrm{MSWD}=1.5$; Fig. $5 \mathrm{H}$; Table 1), interpreted as the time of crystallization.

Fragmental Andesite (BLa)

On the east side of Beaverlodge Lake ('BLa' on Fig. 2B), stratigraphically on top of quartz arenite is a small isolated outcrop of altered vesicular basalt (Bloom Basalt) and more extensive outcrops of unaltered fragmental rhyodacite and andesite; however, the contacts between these various units are obscured by thick flora. A sample of grey-white feldspar and quartz phyric volcaniclastic andesite with resorbed quartz grains and sparse angular lithic clasts

29 was collected. The sample yielded colourless, euhedral prismatic zircon. Four single-grain analyses by CA-ID-TIMS yield $<1 \%$ discordant data with a weighted mean ${ }^{207} \mathrm{~Pb} /{ }^{206} \mathrm{~Pb}$ age of 
$11872.6 \pm 0.9 \mathrm{Ma}(\mathrm{MSWD}=0.95 ;$ Fig. $5 \mathrm{I}$; Table 1$)$ interpreted as the crystallization age of the

2 andesite. The andesite has an $\varepsilon \mathrm{Nd}^{1873}$ value of -0.6 (Fig. 6; Table 3).

4 Faber Group

$5 \quad$ Fiamme-bearing Rhyolite Ignimbrite (SL)

6 In the vicinity of Swan Lake, a sample of rhyolitic to rhyodacitic, fiamme-bearing

7 ignimbrite was collected for U-Pb zircon dating ('SL' on Fig. 2A; Fig. 4F). The sample yielded

8 clear, colourless, euhedral prismatic zircon, some with brownish glass inclusions typical of

9 volcanic zircon. A sub-population, which contained possible cores, was excluded from analysis.

10 Five of six single-grain CA-ID-TIMS analyses are concordant and yield a weighted mean

$11{ }^{207} \mathrm{~Pb} /{ }^{206} \mathrm{~Pb}$ crystallization age of $1868.8 \pm 1.0 \mathrm{Ma}(\mathrm{MSWD}=0.97$; Fig. 5J; Table 1). A single

12 analysis yields a slightly older age of $1876 \pm 1.7 \mathrm{Ma}$ (Fig. 5J; Table 1), and is interpreted to be a

13 xenocryst, or includes an inherited component from a slightly older magmatic event. The rhyolite

14 has an $\varepsilon \mathrm{Nd}^{1869}$ value of -1.0 (Fig. 6; Table 3).

16 Deformed Pluton

17 Weakly Deformed Hornblende-Biotite Granodiorite (ZR)

18 South of Zebulon River ('ZR' on Fig. 2B), hornblende-biotite granodiorite intruded

19 strongly deformed to mylonitic granodiorite (sample 11104156 above). The younger granodiorite

20 contains a moderately developed hornblende- and biotite-defined foliation and, based on this, it

21 was hypothesized to be a component of the Hottah plutonic complex. A sample of this

22 granodiorite yielded zircons that were clear and colourless, with euhedral prismatic habit,

23 although most were fractured multi-facetted prisms. Four single zircon grains were analyzed by

24 CA-ID-TIMS and yielded $<1 \%$ discordant ages with a weighted mean ${ }^{207} \mathrm{~Pb} /{ }^{206} \mathrm{~Pb}$ age of 1869.3

$25 \pm 1.1 \mathrm{Ma}(\mathrm{MSWD}=0.68$; Fig. $5 \mathrm{~K}$; Table 1), interpreted as the crystallization age of the sample.

26 The granodiorite has an $\varepsilon \mathrm{Nd}^{1869}$ value of -2.8 (Fig. 6; Table 3).

Sloan Group

29 Rhyolitic Crystal Tuff (SBr)

30 North of Stairs Bay of Hottah Lake, there are isolated outcrops of rhyolite that are cut by

31 mafic dykes feeding overlying vesicular basalts. The rhyolites are unaltered and well-preserved, 
1 they do not contain the hematite-alteration prevalent in the older Zebulon Formation volcanic

2 rocks. A crystal-rich tuff, with phenocrysts of partially broken alkali feldspar up to $1 \mathrm{~cm}$ across,

3 along with slightly smaller partially resorbed quartz in a groundmass of recrystallized spherules,

4 was collected for U-Pb zircon analysis ('SBr' on Figs. 2; Fig. 4G). The sample yielded

5 colourless, euhedral prismatic zircon. Ten single grain analyses by CA-ID-TIMS yield variably

6 discordant ages between 1858 and $1865 \mathrm{Ma}$ (Table 1). Nine of the ten analyses yield a weighted

7 mean ${ }^{207} \mathrm{~Pb} /{ }^{206} \mathrm{~Pb}$ age of $1861.7 \pm 1.1 \mathrm{Ma}(\mathrm{MSWD}=1.5$; Fig. $5 \mathrm{~L}$; Table 1$)$. With one younger

8 analyses at $1858 \mathrm{Ma}$ rejected, a regression of the data yields an age of $1862.8 \pm 1.8 \mathrm{Ma}$ and a

9 lower intercept within error of zero at $257 \pm 330 \mathrm{Ma}(\mathrm{MSWD}=1.4$; Fig. 5L), interpreted as the

10 crystallization age of the rhyolite. The vesicular basalt has $\varepsilon \mathrm{Nd}^{1862}=0.4$, whereas the dated

11 rhyolite has an $\varepsilon \mathrm{Nd}^{1862}$ value of -0.5 (Fig. 6; Table 3).

13 Dumas Group

14 Rhyodacite Flow (HL)

15 Along the north-striking Wopmay fault zone, mixed basalt, rhyolite, and red arkosic

16 rocks have been assigned to the Dumas Group (Hoffman 1978; Easton 1981; Hildebrand et al.

17 1987b; Jackson and Ootes 2012), and are considered as the eastern equivalent of the LaBine

18 Group (Hildebrand et al. 1987b). Near Ham Lake ('HL' on Fig. 2) a sample of siliceous, purple-

19 weathered plagioclase-phyric rhyodacite with local amygdules, lithic fragments, and preserved

20 flow banding was selected for $\mathrm{U}-\mathrm{Pb}$ zircon dating. Zircons from the rhyodacite sample were

21 stubby to equidimensional prisms. The grains were of various morphology and poor quality,

22 containing numerous cracks and evidence of alteration. These zircons were analyzed using the

23 sensitive high-resolution ion microprobe (SHRIMP II; analytical techniques in Appendix I).

24 Nineteen of twenty analyses yielded $<5 \%$ discordant results with a ${ }^{207} \mathrm{~Pb} /{ }^{206} \mathrm{~Pb}$ weighted mean

25 age of $1869.5 \pm 2.3 \mathrm{Ma}(\mathrm{MSWD}=1.3$; Fig. 5M; Table 2), the interpreted crystallization age of

26 the unit.

28 Discussion

\section{Stratigraphy and Petrological Evolution}

30 The stratigraphic sections in Figure 7 are based on new data and mapping for this study

31 and previously published mapping, nomenclature, and data (Fraser et al. 1972; Hoffman and 
1 McGlynn 1977; Hoffman 1978, 1984; Hoffman et al. 1976; McGlynn 1976, 1979; Wilson 1979;

2 Easton 1980, 1981a,b; Hildebrand 1981, 1984, 1985; Hildebrand et al. 1983, 1984, 1987a, b,

3 2010a, b; St-Onge et al. 1983, 1991; Bowring 1984; Reichenbach 1991; Gandhi 1994; Goad et

4 al. 2000; Gandhi et al. 2001; Gandhi and van Breemen 2005; Bennett and Rivers 2006a,b;

5 Jackson 2008; Shakotko et al. 2012; Jackson and Ootes 2012; Jackson et al. 2013). Figure 7

6 illustrates a minimum 80 million year magmatic evolution from $\sim 1930 \mathrm{Ma}$, the time of intrusion

7 of the Hottah plutonic complex, to ca. $1850 \mathrm{Ma}$, the youngest Great Bear plutonic phases in the

8 Great Bear magmatic zone (Bowring 1984; Gandhi et al. 2001). The detrital zircon record of the

9 Holly Lake metamorphic complex indicates the presence of a $>2.0$ to 1.95 Ga magmatic arc in its

10 source environment, potentially suggesting a >150 million year magmatic evolution of the

11 Hottah terrane through Great Bear magmatism. The U-Pb crystallization ages of the younger ca.

121913 Ma plutons, e.g., the dated tonalite and associated gabbros, are in general complexly

13 intermingled with a full-range of intrusive phases and have trace-element attributes similar to

14 arc-derived magmas (Figs. 4B, 8, 9A, 10A-B; Table A1). Some of the major elements and

15 mobile trace elements show various signs of secondary alteration (Fig. 8A-B, 9A); however, the

16 relatively immobile trace elements and rare earth elements (REE) appear unaffected (Fig. 8C,

17 9A, 10A-B; Pearce 1996).

18 The Bell Island Bay Group erupted in a subaerial environment between ca. 1906 and

$191895 \mathrm{Ma}$ (Figs. 5 and 7) and this is a key time-frame for deciphering Hottah terrane evolution.

20 Our field mapping and geochronological results, and those in Reichenbach (1991), indicate the

$21 \quad 1905.6 \pm 1.4$ Ma Zebulon Formation (Fig. 5E) is dominated by subaerial rhyolite, with lesser

22 vesicular basalt. Using $\mathrm{SiO}_{2}$ contents, Reichenbach (1991) argued that the Zebulon Formation

23 plot as a continuum from basalt to rhyolite, but is dominantly andesitic in composition

24 (Reichenbach 1991). However, these rocks show visible evidence of alteration, such as

25 bleaching, reddening, or brecciation, cemented by hematite, also discussed by Reichenbach

26 (1991). The rhyolites plot on a line between $\mathrm{Al}_{2} \mathrm{O}_{3}$ and $\mathrm{K}_{2} \mathrm{O}$, on the chemical index of alteration

27 plot $(\mathrm{K}: \mathrm{Ca}+\mathrm{Na}=$ close to 100:0) and plot on a tie line on Shand's Index diagram (Fig. 8A-B;

28 Table A1; Reichenbach 1991). These major elements are not primary rhyolite compositions and

29 are best interpreted as being influenced by post-volcanic alteration, suggesting that the major

30 elements (e.g., $\mathrm{SiO}_{2}$ ) are not rigorous discriminators of rock type (Fig. 8A-B). The more robust

31 HFSE ratios (Pearce 1996) of the Zebulon Formation volcanic rocks demonstrate a bimodal 
1 distribution of basalt and dacite/rhyolite with few rocks of intermediate composition (Fig. 8C;

2 Table A1), consistent with our field observations and those documented on the map and in the text of Reichenbach (1991). A few samples from Reichenbach (1991) contain anomalously high

4 zirconium (Fig. 8D) and plot in the alkaline/sub-alkaline trachyte field (Fig. 8E). Cross-checking

5 the sample locations on the map in Reichenbach (1991) indicate that most of these high zirconium samples were collected along strike in a single mapped flow (unit PZ-Ld). Regardless,

7 these are not typical arc andesites (Kelemen et al. 2004). Like some of the major elements, some

8 of the trace-elements may be biased by alteration, particularly the mobile trace elements like $\mathrm{Sr}$

9 and possibly $\mathrm{Eu}$ (due to their relationship with plagioclase and the obvious loss of $\mathrm{Ca}$ and $\mathrm{Na}$ in

10 these rocks; Fig. 8A-B). The remaining trace-elements and REE appear to have escaped

11 extensive alteration and normalized diagrams indicate the Zebulon rhyolites are comparable to

12 high-temperature rhyolites derived from partial melts from a basaltic source (Fig. 9; e.g.,

13 Nicholson et al. 1991; Cousens 1996). These Zebulon Formation felsic rocks are similar to high-

14 silica rhyolites from suprasubduction zone environments, such as the Taupo volcanic zone in

15 New Zealand, the Long Valley caldera of the western USA (Fig. 9B), as well as non-arc settings

16 such as Krafla volcano in Iceland (Cole 1990; Jónasson 1994; Cousens 1996; Moulton et al.

17 2011). The Zebulon Formation basalts are geochemically comparable to low-Ti basalts derived

18 from a modified mantle wedge in a suprasubduction zone setting (Figs. 9C and 10D-E; Pearce

19 and Norry 1979; Shervais 2001; Pilet et al. 2004). This suprasubduction zone signature in the

20 Zebulon Formation volcanic rocks (Figs. 8-10), and the fact they erupted subaerially on a

21 plutonic basement that was unroofed within $7 \mathrm{Ma}$ of crystallization, is most compatible with a

22 suprasubduction zone environment undergoing rapid extension (Umhoefer 2011). Whether or not

23 these plutonic and volcanic rocks were derived from an active subduction zone, or from a

24 previously subduction-modified mantle, is not resolvable based on geochemistry (e.g., Bryan et 25 al. 2015).

26 The ca. 1900 Ma Conjuror Bay Formation marginal marine quartz arenite sits

27 unconformably on the older Hottah stratigraphy, including the Zebulon Formation (Fig. 4E;

28 (Hildebrand 1984, 1985; Reichenbach 1991; Jackson and Ootes 2012), and marks drowning of

29 the rifting arc (Fig. 7). A well-developed regolith occurs at this unconformity within the

30 underlying Hottah porphyry (Fig. 4E) and it is quite possible that the processes altering this

31 horizon were also responsible for the significant alteration in the underlying units of the Zebulon 
1 Formation (Shakotko et al. 2012). Hildebrand (1984, 1985) assigned the Conjuror Bay

2 Formation as the base of the ca. $1875 \mathrm{Ma}$ LaBine Group in the Camsell River district, whereas at

3 Hottah Lake the Conjuror Bay Formation is overlain by the Bloom sequence, now dated at 1895

$4 \pm 2.3 \mathrm{Ma}$ (Fig. 5F and 7). Consequently, we argue that the Conjuror Bay Formation and Bloom

5 Basalts are part of the Bell Island Bay Group rather than the LaBine Group (as in Table 1 in

6 Reichenbach 1991; Fig. 7). It is likely that the Moose Bay tuff (Hildebrand 1984) or the $1876.4 \pm$

$7 \quad 2.4$ Ma volcanic rocks at DeVries Lake (Fig. 5H), represent the lowest stratigraphy in the Great

8 Bear volcanic arc.

9 The Bloom Basalts and lesser rhyodacites are temporally and geochemically correlative

10 with the $1892.9 \pm 1.5 \mathrm{Ma}$ Grant Subgroup east of the Wopmay fault zone (Fig. 6; Easton 1981;

11 Reichenbach 1991). The basalts have geochemical attributes, such as HFSE concentrations (e.g.,

$12 \mathrm{Th}, \mathrm{Nb}, \mathrm{Ta}$ concentrations) that are best explained as a result of melting from a suprasubduction

13 zone, or subduction-modified mantle (Figs. 9D and 10B-E; Table A1; Pearce and Norry 1979;

14 Pilet et al. 2004) and the stratigraphic position of these basalts is consistent with their eruption in

15 a highly attenuated arc, or marginal basin setting (Figs. 7 and 10; Wilson 1979; Easton 1980;

16 Reichenbach 1991), which was previously termed the Akaitcho seaway (Fig. 3B; Reichenbach

17 1991). In the west, the basalts were erupted on the older Hottah terrane stratigraphy, but to the

18 east we have been unable to demonstrate conclusively if the Grant Subgroup basalts were

19 erupted on Archean basement, or if they were thrust over this basement (Fig. 7; Jackson and

20 Ootes 2012; also see Easton 1980, 1981b; St-Onge et al. 1983; Hildebrand et al. 2010a). Both the

21 Bloom Basalt and Grant Subgroup basalt samples have modestly positive $\varepsilon_{\mathrm{Nd}}{ }^{1895}$. This indicates

22 their parental melts did not extensively interact with earliest Proterozoic or Archean basement

23 (Fig. 6; Table 2) and further supports their eruption in a highly attenuated suprasubduction zone

24 environment, be it rifted arc or marginal basin.

25 Due to erosion and overprinting by younger magmatism, the stratigraphy of the Hottah

26 terrane (Fig. 7) is preserved in a disconnected fashion over about $1800 \mathrm{~km}^{2}$ (Fig. 2). The limited

27 extent of preservation means it is not possible to constrain with certainty the larger-scale

28 processes driving the ca. 1930 to ca. 1895 Ma petrological evolution. However, the evolving

29 magmatic system is consistent with a rapidly rifting arc setting. Such an environment may result

30 from a variety of subduction zone adjustments including slab roll-back, delamination, or

31 flattening, or possibly the development of a pseudo-slab window from outboard ridge subduction 
1 (e.g., Dickinson 2002; Thorkelson et al. 2011; Giba et al. 2013). However, the suprasubduction

2 zone geochemical signature of the rocks can also be attainted from a prior, rather than active,

3 subduction-modified mantle (e.g., Bryan et al. 2014). What we have not found is support of a

4 lateral migration in magmatic activity from west to east across the Hottah terrane during this

5 time-interval as proposed by Hildebrand et al. (2010a). As discussed below, this finding has

6 significant implications on the tectonic interpretations for the Hottah terrane.

The Treasure Lake Group is preserved in the southern Great Bear magmatic zone (Fig. 2)

8 and represents an enigmatic sedimentary unit. It has a maximum deposition age of ca. $1885 \mathrm{Ma}$,

9 it was deformed and metamorphosed prior to or during the onset of Great Bear magmatism at ca.

$101875 \mathrm{Ma}$ (Fig. 7; Gandhi and van Breemen 2005; Bennett and Rivers 2006b), and may represent

11 a syn-collisional basin similar to the ca. 1882 Ma Recluse Group in the Coronation margin

12 (Hoffman et al. 2011). It is not known if there is any place where the Treasure Lake Group is in

13 contact with the older Bell Island Bay Group, Hottah plutonic complex, or Holly Lake

14 metamorphic complex. The Treasure Lake Group contains older Archean detrital zircons with

15 ages typical of the Slave craton, in addition to 2.33 to $2.26 \mathrm{Ga}$ detrital zircons that were

16 attributed to a Hottah terrane source (Gandhi and van Breemen 2005); however, such ages are

17 also characteristic of Paleoproterozoic tectonic events recorded in the western Rae craton (e.g.,

18 Davis et al. submitted).

19 The Great Bear magmatic zone volcanic rocks unconformably overly Hottah terrane

20 rocks in the central and northern areas and the Treasure Lake Group in the south (Fig. 2;

21 Hildebrand 1984, 1985; Hildebrand et al. 1983; Goad et al. 2000; Gandhi et al. 2001; Jackson

22 2008; Jackson and Ootes 2012). The newly obtained U-Pb crystallization ages for Great Bear

23 volcanic rocks support previous data that indicate the LaBine Group volcanic arc erupted

24 between ca. 1878 and 1870 Ma (Figs. 5 and 7; Table 3; Bowring 1984; Bennett and Rivers

25 2006a). The $1868.8 \pm 1.0$ Ma rhyolite in this study is similar in both age and geochemistry to the

26 dominantly rhyolitic Faber Group in the southern Great Bear magmatic zone (Figs. 7-10; Gandhi

27 et al. 2001; Azar 2007). In addition, the 1869.5 \pm 2.3 Ma Dumas Group that spatially coincides

28 with Wopmay fault zone (Figs. 2 and 7) is indistinguishable in age from the Faber Group and the

29 deformed 1869.3 \pm 1.1 Ma Great Bear hornblende-biotite granodiorite to the west (Fig. 5).

30 Volumetrically dominant ca. 1865 Ma monzonitic to granitic plutonic phases (Ghandi et al.

31 2001; Bennett and Rivers 2006a) are not ductiley deformed. We, therefore, estimate the tectonic 
1 event that led to the deformation of the volcanic rocks and hornblende-biotite granodiorite to

2 have occurred at approximately $1867 \mathrm{Ma}$, coincident with a significant deformation event now 3 recognized to the east of the Wopmay fault zone (Jackson et al. 2013).

$4 \quad$ Relatively pristine $1862.8 \pm 1.8 \mathrm{Ma}$ felsic tuff and associated amygdaloidal basalts that 5 occur east of Hottah Lake are likely correlative with the more northerly Sloan Group volcanic 6 rocks and intrusive porphyries (Hoffman et al. 1976; Hoffman 1978; Bowring 1984) and a 7 rhyodacitic ignimbrite that post-dates mineralization at the Sue-Diane $\mathrm{Cu}$-Au prospect to the 8 south (Fig. 7; Gandhi et al. 2001). The bimodal Sloan Group volcanic package, recognized in 9 this study (Figs. 7-10; Table A1), post-dates the ca. 1865 Ma plutonic events (e.g., Gandhi et al.

10 2001; Bennett and Rivers 2006a; Hildebrand et al. 2010b) and pre-dates the final ca. $1855 \mathrm{Ma}$ 11 rapakivi-textured plutonism (Gandhi et al. 2001), as well as the younger ca. $1843 \mathrm{Ma}$

12 syenogranite magmatism (Bowring 1984).

\section{Whence came Hottah terrane?}

The Slave craton and overlying Coronation margin did not share a common tectonostratigraphic, or plutonic history with the Hottah terrane prior to ca. $1876 \mathrm{Ma}$ (Bowring

17 1984; Hildebrand et al. 2010a; Jackson et al. 2013). In addition, detrital zircons and $\mathrm{Nd}$ and Pb

18 isotope data do not support that the Hottah terrane was built on attenuated Slave craton crust 19 (Bowring and Podosek 1989; Housh et al. 1989; Hildebrand et al. 2010a; Davis et al. submitted).

20 The simple marginal basin model entirely within Slave crust, depicted in Figure 3B, is therefore

21 ruled as an unfavourable solution for the origin and evolution of Hottah terrane (Bowring and

22 Grotzinger 1992).

Samarium-Neodymium isotopic values from the Hottah terrane and Great Bear magmatic 24 zone were used to indicate a juvenile ca. 2.0-2.4 Ga crustal basement (Bowring and Podosek

25 1989). Our new Nd isotopic results are similar (Fig. 6; Table 3) and provide further information 26 on the nature and provenance of the yet undiscovered $>1950 \mathrm{Ma}$ basement. The $\mathrm{T}_{\mathrm{DM}}$ ages range

27 from 2.2 to $2.5 \mathrm{Ga}$ (Table 3). One interpretation is that these could represent an accurate measure 28 of a crustal protolith age (e.g., Bowring and Podosek 1989). Alternatively, these values record a 29 mixture of juvenile mantle and a crustal end member, as is typical of igneous rocks in magmatic 30 arc settings. This would suggest a minimum age of the crustal endmember at ca. $2.5 \mathrm{Ga}$, the 31 maximum $\mathrm{T}_{\mathrm{DM}}$ age (Table 3 ). Assuming a continental arc setting, which is consistent with the 
1 detrital zircon $\varepsilon \mathrm{Hf}$ and $\delta^{18} \mathrm{O}$ results in the Hottah terrane (Davis et al. submitted), this requires

2 the Hottah basement to be made up of either juvenile Neoarchean crust, or Neoarchean crust that 3 was recycled in the Proterozoic, not juvenile Paleoproterozoic crust.

4 The independent evolution and the transition from passive to active Coronation margin 5 sedimentation are cited to support the micro-continent - continent collision model (Fig. 3A), in

6 which the Hottah terrane evolved as an <1940 Ma exotic arc built on a ca. 2.0-2.4 Ga basement.

7 In this model, arc magmatism began after the opening of the Coronation ocean and the micro-

8 continent and overriding arc accreted to the Slave craton at ca. $1882 \mathrm{Ma}$, the onset of the

9 Calderian orogeny (Fig. 3A; Hildebrand 1981; Bowring and Grotzinger 1992; Cook and Erdmer

10 2005; Hildebrand et al. 2010a; Hoffman et al. 2011; Hoffman 2012). The rift to drift transition in

11 the Coronation margin is recorded at ca. $2014 \mathrm{Ma}$ (Hoffman et al. 2011), followed by passive

12 margin sedimentation at ca. $1970 \mathrm{Ma}$ (Bowring and Grotzinger 1992). The detrital zircon record

13 in the ca. 1950 Ma Holly Lake metamorphic complex metasedimentary rocks, the oldest exposed

14 bedrock of the Hottah terrane, indicates that arc magmatism in Hottah terrane began prior to ca.

$152.0 \mathrm{Ga}$ (Davis et al. submitted). Thus, it is difficult to reconcile active arc magmatism above a

16 long lived $>2.0$ to $1.89 \mathrm{Ga}$, west-dipping arc system (Fig. 3A), as arc magmatism initiated within

17 the Hottah terrane prior to, or simultaneously with the opening of the $<2.01$ Ga Coronation

18 oceanic basin (Hoffman et al. 2011). The model in Figure 3A is therefore ruled as an

19 unfavourable solution for the origin and evolution of Hottah terrane (Davis et al. submitted).

20 The Holly Lake metamorphic complex metasedimentary rocks have a detrital zircon

21 provenance that strikingly matches the igneous history of the western Rae craton (Davis et al.

22 submitted), including a record of the Queen Maud, Arrowsmith, Taltson-Thelon and Ksituan

23 magmatic events (Bostock and Loveridge 1988; van Breemen and Henderson 1988; Villeneuve

24 et al. 1993; Ross 2002; Berman et al. 2013). These domains were potentially tied to Slave craton

25 prior to the deposition of the Holly Lake metamorphic complex (Hoffman 1987, 1988a). If that

26 crust was the source of the Holly Lake metamorphic complex detritus, this would indicate that

27 the Hottah terrane was on the North American margin prior to ca. 1950 Ma. The Holly Lake

28 metamorphic complex was intruded by the Hottah plutonic complex and overlain by the Bell

29 Island Bay Group, which coincides with recorded extension-related metamorphism in the

30 Coronation margin (St-Onge and King 1986, 1987), deposition of the Akaitcho Group (Easton

31 1980, 1981a, b; Hoffman et al., 2011), and possibly the early stages of Hepburn Intrusive Suite 
1 (Bowring 1984; Lalonde 1989). While isotopic arguments have been used to suggest that the 2 Hepburn intrusive suite is exotic to the Slave craton (Bowring and Podosek 1989; Housh et al. 3 1989; Hildebrand et al. 2010a), the alternative interpretation that they intruded an attenuated 4 basin is equally permissible (Lalonde 1989). The results and coincidences, in addition to others

5 detailed below, allow the exploration of an alternative hypothesis for the evolution and arrival of 6 the Hottah terrane to its present location.

8 An Alternative Model: Terrane Translation

The ca. 20 million year evolution from 1912.9 \pm 0.8 Ma Hottah plutonic complex

11 volcanism, is best interpreted within a framework of rapid extension, and directly comparable in

12 its nature and duration to rifts in active continental margins. An analogue may be Baja California

13 (Fig. 11) where the peninsula began as part of an arc terrane on the North American plate,

14 subsequently rifted off and was transferred via transtensional shear to the Pacific plate, and was

15 accommodated by opening of the Gulf of California marginal basin. In the last ca. 12 million

16 years, Baja has been dextrally transported at least $300 \mathrm{~km}$ north and west of its origin (Fig. 11A:

17 Umhoefer 2011; Sutherland et al. 2012; Bennett et al. 2013; also see Bryan et al. 2014), while

18 the Gulf of California evolved on top of the previous and deceased arc system (Fig. 11A;

19 Umhoefer 2011; Bennett et al. 2013). Basin opening and strike-slip translation have also been

20 related to the evolution of thick slab subduction that transitions to strike-slip faulting in Alaska,

21 also over a short time-period (Trop et al. 2012). The Taupo volcanic zone analogy is another

22 example of upper plate extension, driven by slab roll back, within a complex arc - back-arc

23 environment adjacent to the transition of the subduction zone to a large-scale transtensional shear

24 zone, the Alpine fault (e.g., Wallace et al. 2012; Giba et al. 2013).

25 Based on the active margin translation model (extension driven strike-slip movement),

26 the evolution of the ca. 1913 to 1893 Ma Bell Island Bay Group could record the birth of the

27 Hottah terrane, when it was rifted off of its parent plate to form a new micro-plate (Fig. 11B). To

28 account for the detrital zircon record in Hottah terrane (Davis et al. submitted), and the lack of

29 Slave craton basement, the absolute starting position would have been to the south, in an active

30 margin, possibly related to the development of the Taltson or Ksituan magmatic zones, but

31 potentially as close as just off the southwest flank of the Slave craton (Fig. 11B; Davis et al. 
1 submitted). In this model, rather than Hottah terrane arriving adjacent to the Slave craton above a

2 west-dipping subduction system, it arrived by extension-driven dextral transport during basin

3 opening. This can be envisaged in terms of the future transport of the Baja micro-plate adjacent

4 to California (Fig. 11). If we were able to look at that margin in ca. 20 million years, it is

5 possible Baja could be juxtaposed to central California, and look exotic to it, even though they

6 began from the same plate. The current passive margin off western California will be equally

7 displaced northwestward. In the Hottah terrane model, the stratigraphy of the Bell Island Bay

8 Group (Fig. 7) is recording this extension-driven translation. The timing of the Hottah terrane

9 arrival was sometime around ca. $1882 \mathrm{Ma}$, the time of Recluse Group foredeep sedimentation

10 and onset of the Calderian orogeny (Hildebrand et al. 2010a; Hoffman et al. 2011). Significantly,

11 in the southwest Slave craton, the Great Bear magmatic zone is in direct contact with the Slave

12 craton (sensu stricto) along the Wopmay fault zone, and there is no Coronation margin in this

13 region (Fig. 1 and 2A; Jackson et al. 2006). We suggest that the southwest Slave craton and

14 overlying Coronation margin, if it existed in the southern Wopmay orogen, may have been

15 transported northward along this fault system.

16 If this rift model and suggested regional correlations are correct, then the Hottah terrane

17 represents the southwestern margin of the rifted basin, whereas ca. 1.9 Ga components of the

18 western and southern Slave craton, along with overlying Coronation margin and potentially

19 Wilson Island or Union Island groups in the East Arm basin (Bowring et al. 1984; Johnson

20 1990), represent the northeastern continental margin of the rifted basin (Fig. 11B). Circa $1.9 \mathrm{Ga}$

21 rift-related rocks have not been discovered in the Taltson magmatic zone, but the evolution of

22 many volcano-sedimentary units there remain understudied (K. Bethune pers. comm. 2015).

23 Further complicating this is the fact that the western margin of the Taltson and entire Ksituan

24 magmatic zones are hidden below the Phanerozoic sedimentary cover (Fig. 1A). The Hottah

25 terrane translation model presented here post-dates the movement on the 1.97-1.92 Ga Great

26 Slave Lake shear zone that bounds Slave craton and Taltson magmatic zone (Hofmann 1987;

27 Hanmer et al. 1992) and pre-dates the ca. 1.84-1.75 Ga MacDonald Fault movement (Fig. 1;

28 Ross 2002). Further studies are required to demonstrate if it is geometrically possible to

29 accommodate the movement of Hottah terrane as suggested. Deciphering the destination of the

30 removed western Slave craton and Coronation margin, and evaluating putative correlations to the

31 East Arm basin, are also key factors for testing this model. A currently untestable implication is 
1 what effects such a model has on the correlation and assignments of the terranes across the

2 MacDonald Fault in the subsurface of Alberta (Fig. 1A; Villeneuve et al. 1993; Ross 2002).

Oblique east-dipping subduction has been suggested to account for Great Bear magmatism at $1.875 \mathrm{Ga}$ (Hildebrand et al. 1987) and is further supported in this study. However,

5 if this subduction geometry had been established by ca. 2.0 Ga or earlier, rather than at $1.88 \mathrm{Ga}$, then Hottah terrane rocks could have evolved marginal to terranes to the south, such as Taltson or Ksituan magmatic zones (Figs. 1 and 11), accounting for the detrital zircon record in the

8 Hottah terrane (Davis et al. submitted). While a ca. 1.88 Ga micro-continent - continent collision model (Fig. 3A) is not entirely ruled out in this study, a one-sided, long-lived subduction system

11 progression in magmatism and the evolution of the Hottah terrane and Great Bear magmatic 12 zone, and potentially a migration from south to north (in present coordinates), finally impinging

13 on the Slave craton margin and resulting in the Great Bear arc flare-up. An always east-dipping

14 subduction system also helps explain the east-dipping stacked lithospheric mantle under the 15 western Slave craton and Great Bear magmatic zone (Cook et al. 1999; Cook and Erdmer 2005;

16 Wu et al. 2005; Oueity and Clowes 2011), including the frozen oceanic plate that was likely

17 related to the late arrival of the Nahanni terrane to the west (Fig. 1B). Late stage, NE-striking, 18 brittle-dextral faulting, such as the dextral McDonald Fault, continued to the Cordilleran thrust

19 front (Fig. 1A; Pilkington et al. 2000; Aspler et al. 2003; Hayward and Corriveau 2014) and

20 therefore brittle deformation post-dated arrival of the Nahanni terrane (cf. Hayward and

21 Corriveau 2014). It is speculated here that these faults were related to some tectonic adjustments

22 even further west, or perhaps even related to the Trans-Hudson orogen to the southeast.

\section{Conclusions}

This study provides new geochronological and geochemical results for the exposed

26 Hottah terrane and Great Bear magmatic zone of the northwest Canadian Shield that further 27 highlight an evolving tectonostratigraphy from ca. 1950 to $1850 \mathrm{Ma}$ (Hildebrand et al. 2010a, b;

28 Davis et al. submitted). The oldest bedrock is the ca. 1950 Ma Holly Lake metamorphic

29 complex, which was intruded by the Hottah plutonic complex at ca. $1930 \mathrm{Ma}$ and $1913 \mathrm{Ma}$. The

30 youngest of these plutons were unroofed and unconformably overlain by Beaverlodge Lake

31 sandstone and the Bell Island Bay Group, beginning with the ca. 1906 Ma Zebulon Formation 
1 rhyolite-dominated subaerial volcanic rocks. The Conjuror Bay Formation marginal marine

2 quartz arenite was deposited on top and capped by the ca. $1895 \mathrm{Ma}$ Bloom Basalts and lesser

3 rhyodacite. These basalts can be chronologically and geochemically correlated with the ca. 1893

4 Ma Grant Subgroup, which overly mylonitzed Archean granites east of the Wopmay fault. The

5 stratigraphic and petrological evolution of the Hottah terrane from 1913 to $1893 \mathrm{Ma}$ is

6 compatible with an evolving arc that rapidly evolved from subduction to a transtensional

7 environment. The results of this study and detrital zircon data in Davis et al (submitted) suggest

8 the Hottah terrane began on the margins of the Taltson (or Ksituan) magmatic zones, south of its

9 current resting place, and was dextrally transported by transtensional shear movement during

10 basin opening as recorded by the Bell Island Bay Group. Transtensional shear movement, or

11 terrane translation (Umhoefer, 2011) may prove a valuable alternative to subduction-collision

12 models invoked for the tectonic evolution of relict terranes globally.

13 The Great Bear arc flare-up began at ca. $1876 \mathrm{Ma}$ and continued through ca. $1869 \mathrm{Ma}$

14 and was driven by oblique east-dipping subduction (Hildebrand 1981; Hildebrand et al. 1987a,

15 2010a). Voluminous felsic-intermediate plutonism followed and the bimodal Sloan Group

16 erupted at 1862 Ma. Post-orogenic, ca. 1855 Ma Rapakivi-textured granitoids and ca. 1845

17 syenogranites were the last magmatic pulses (Bowring 1984; Gandhi et al. 2001). The results and

18 models presented for the Hottah terrane and Great Bear magmatic zone are fully compliant with

19 the geophysical models that indicate an east-dipping stacked lithospheric mantle (e.g., Cook et

20 al. 1999). On a broader scale the age continuum of the Hottah terrane and Great Bear magmatic

21 zone matches the complex interplay of continental-scale subduction processes from ca. 2.0 Ga to

22 the amalgamation of the supercontinent Nuna.

\section{ACKNOWLEDGEMENTS}

P. Acosta-Góngora, B. Azar, V. Bennett, S. Byron, L. Corriveau, S. Gleeson, M. Hewton,

27 D. MacKay, L. Newton, H. Sandeman, P. Shakotko, D. Snyder, and L. Smar aided with relevant 28 components of South Wopmay bedrock mapping and/or ideas that have benefited this study. T

29 Pestaj, C. Lafontaine, L. Cataldo and J. Peressini provided technical expertise in the acquisition

30 of the U-Pb data. Sm-Nd isotopic work was overseen by E.A. Spencer and B. Cousens at

31 Carleton University. M. Easton kindly provided rhyodacite samples 361.8 and 362.8. Financial 
1 support was provided by NWT Geoscience Office South Wopmay bedrock mapping project

2 (NTGO \#0078), the Geological Survey of Canada GEM IOCG project (ESS contribution

3 ID20053), and Polar Continental Shelf Project (500-07, 507-09, 004-10, and 313-11). Early

4 versions of the manuscript benefited from comments by M. St-Onge, T. Chacko, and A. Cavosie.

5 The authors thank T. Chacko and K. Bethune for thorough and constructive reviews and F. Corfu

6 and A. Polat for editorial handling of the manuscript. 


\section{REFERENCES}

2 Aspler, L.B., Pilkington, M., and Miles, W.F. 2003. Interpretations of Precambrian basement

3 based on recent aeromagnetic data, Mackenzie Valley, Northwest Territories. Geological Survey

4 of Canada, Current Research 2003-C2, 13 p.

5

6 Azar, B. 2007. The lithogeochemistry of volcanic and subvolcanic rocks of the FAB lake area,

7 Great Bear Magmatic Zone, Northwest Territories, Canada. Unpublished B.Sc. thesis, University 8 of Toronto, $96 \mathrm{p}$.

10 Badham, J.P.N. 1973. Calc-alkaline volcanism and plutonism from the Great Bear batholith, 11 N.W.T. Canadian Journal of Earth Sciences, 10: 1319-1328.

13 Bennett, S.E.K., Oskin, M.E., and Iriondo, A. 2013. Transtensional rifting in the proto-Gulf of

14 California near Bahía Kino, Sonora, México. Geological Society of America Bulletin, 125: 1752151782.

16

17 Bennett, V., and Rivers, T. 2006a. U-Pb ages of zircon primary crystallization and inheritance

18 for magmatic rocks of the southern Wopmay orogen, Northwest Territories. Northwest

19 Territories Geological Survey, NWT Open Report 2006-006, 65 p. www.nwtgeoscience.ca

21 Bennett, V., and Rivers, T. 2006b. U-Pb ages of detrital zircons from the southern Wopmay

22 orogen, Northwest Territories. Northwest Territories Geological Survey, NWT Open Report

23 2006-007, 30 p. www.nwtgeoscience.ca 
2 Berman, R.G., Pehrsson, S., Davis, W.J., Ryan, J.J., Qui, H., and Ashton, K.E. 2013. The

3 Arrowsmith orogeny: geochronological and thermobarometric constraints on its extent and

4 tectonic setting in the Rae craton, with implications for pre-Nuna supercontinent reconstruction.

$5 \quad$ Precambrian Research, 232: 44-69.

6

7 Bostock, H.H., and Loveridge, W.D. 1988. Geochronology of the Taltson magmatic zone and its

8 eastern cratonic margin, District of Mackenzie. Geological Survey of Canada, Paper 88-2, pp.

$9 \quad 59-65$.

11 Bowring, S.A. 1984. U-Pb zircon geochronology of early Proterozoic Wopmay orogen, N.W.T.

12 Canada: an example of rapid crustal evolution. Unpublished Ph.D. thesis, University of Kansas, $13148 \mathrm{p}$.

14

15 Bowring, S.A., and Grotzinger, J.P. 1992. Implications of new chronostratigraphy for tectonic

16 evolution of Wopmay orogen, Northwest Canadian Shield. American Journal of Science, 292: 11720.

18

19 Bowring, S.A., and Podosek, F.A. 1989. Nd isotopic evidence from Wopmay orogen for 2.0-2.4

20 Ga crust in western North America. Earth and Planetary Science Letters, 94: 217-230. 
1 Bowring, S.A., Van Schums, W.R., and Hoffman, P.F. 1984. U-Pb zircon ages from Athapuscow

2 Aulacogen, East Arm of Great Slave Lake, NWT, Canada. Canadian Journal of Earth Sciences,

3 21: 1315-1324.

4

5 Bryan, S.E., Orozco-Esquivel, T., Ferrari, L., and López-Martinez, M. 2014. Pulling apart the

6 Mid to Late Cenozoic magmatic record of the Gulf of California: is there a Comondú arc, Edited

7 by A. Gómez-Tuena, S.M. Straub, and G.F. Zellmer. Orogenic Andesites and Crustal Growth.

8 Geological Society, London, Special Publications, 385, pp. 389-407.

10 Cole, J.W. 1990. Structural control and origin of volcanism in the Taupo volcanic zone, New

11 Zealand: Bulletin of Volcanology, 52: 445-459.

12

13 Cole, R.B., and Stewart, B.W. 2009. Continental margin volcanism at sites of spreading ridge

14 subduction: Examples from southern Alaska and western California. Tectonophysics, 464: 11815136.

16

17 Cook, F.A., van der Velden, A., Hall, K.W., and Roberts, B. 1999. Frozen subduction in

18 Canada's Northwest Territories: Lithoprobe deep lithospheric reflection profiling of the western

19 Canadian Shield. Tectonics, 18: 1-24.

20

21 Cook, F.A., and Erdmer, P. 2005. An $1800 \mathrm{~km}$ cross section of the lithosphere through the

22 northwestern North American plate: lessons from 4.0 billion years of Earth's history. Canadian

23 Journal of Earth Sciences, 42: 1295-1311. 
2 Cousens, B.L. 1996. Magmatic evolution of Quaternary mafic magmas at Long Valley Caldera

3 and the Devils Postpile, California: effects of crustal contamination on lithospheric mantle-

4 derived magmas. Journal of Geophysical Research, 101: 27,673-27,689.

5

6 Davis, W.J., and Bleeker, W. 2007. New ages for Paleoproterozoic mafic intrusions in the

7 western Slave Province and their potential relationship with tectonic events in the adjacent

8 Wopmay orogen. Geological Association of Canada/Mineralogical Association of Canada,

9 Yellowknife, Northwest Territories, Abstracts Vol. 32, p. 20.

11 Davis, W.J., Ootes, L., Newton, L., Jackson, V.A., and Stern, R.A. Characterization of the

12 Paleoproterozoic Hottah terrane, Wopmay Orogen using multi-isotopic (U-Pb, Hf and O) detrital

13 zircon analyses: An evaluation of linkages to northwest Laurentian Paleoproterozoic domains.

14 Precambrian Research, in press, DOI:10.1016/j.precamres.2015.08.012.

16 DePaolo, D.J. 1981. Neodymium isotopes in the Colorado Front Range and implications for 17 crust formation and mantle evolution in the Proterozoic. Nature, 291: 193-197.

19 Dickinson, W.R. 2002. The Basin and Range Province as a composite extensional domain.

20 International Geology Review, 44: 1-36. 
1 Easton, M.E. 1980. Stratigraphy and geochemistry of the Akaitcho Group, Hepburn Lake map

2 area, District of Mackenzie: an initial rift succession in Wopmay orogen (Early Proterozoic).

3 Geological Survey of Canada, Paper 80-1B, pp. 47-57.

4

5 Easton, M.E. 1981a. Stratigraphy of the Akaitcho Group and the development of an Early

6 Proterozoic Continental margin, Wopmay orogen, Northwest Territories, Edited by F.H.A.

7 Campbell. Proterozoic Basins of Canada. Geological Survey of Canada, Paper 81-10, pp. 79-95.

9 Easton, M.E.. 1981b. Geology of Grant Lake and Four Corners Lake map areas, Wopmay

10 orogen, District of Mackenzie. Geological Survey of Canada, Paper 81-1B, pp. 83-94.

12 Fraser, J.A., Hoffman, P.F., Irvine, T.N., and Mursky, G. 1972. The Bear Province. Geological

13 Association of Canada Special Paper 11, pp. 454-503.

14

15 Gandhi, S.S. 1994. Geological setting and genetic aspects of mineral occurrences in the southern

16 Great Bear magmatic zone, Northwest Territories, Edited by W.D. Sinclair and D.G. Richardson.

17 Studies of Rare-Metal Deposits in the Northwest Territories. Geological Survey of Canada,

18 Bulletin 475, pp. 63-96.

20 Gandhi, S.S., and van Breemen, O. 2005. SHRIMP U-Pb geochronology of detrital zircons from

21 the Treasure Lake Group - new evidence for Paleoproterozoic collisional tectonics in the

22 southern Hottah terrane, northwestern Canadian Shield. Canadian Journal of Earth Sciences, 42:

$23 \quad 833-845$. 
2 Gandhi, S.S., Mortensen, J.K., Prasad, N., and van Breemen, O. 2001. Magmatic evolution of the

3 southern Great Bear continental arc, northwestern Canadian Shield: geochronological

4 constraints. Canadian Journal of Earth Sciences, 38: 767-785.

5

6 Giba, M., Walsh, J.J., Nicol, A., Mouslopoulou, V., and Seebeck, H. 2013. Investigation of the

7 spatio-temporal relationship between normal faulting and arc volcanism on million-year time

8 scales. Journal of the Geological Society London, 170: 951-962.

10 Goad, R.E., Mumin, A.H., Duke, N.A., Neale, K.L., Mulligan, D.L., and Camier, W.J. 2000. The

11 NICO and Sue-Dianne Proterozoic, iron oxide-hosted, polymetallic deposits, Northwest

12 Territories: application of the Olympic Dam model in exploration. Exploration and Mining

13 Geology, 9: 123-140.

14

15 Goldstein, S.L., O’Nions, R.K., and Hamilton, P.J. 1984. A Sm-Nd study of atmospheric dusts

16 and particulates from major river systems. Earth and Planetary Science Letters, 70: 221-236.

18 Hanmer, S., Bowring, S., van Breemen, O., and Parrish, R. 1992. Great Slave Lake shear zone,

19 NW Canada: mylonitic record of Early Proterozoic continental convergence, collision and

20 indentation. Journal of Structural Geology, 14: 757-773. 
1 Hayward, N., and Corriveau, L., 2014. Fault reconstructions using aeromagnetic data in the

2 Great Bear magmatic zone, Northwest Territories, Canada. Canadian Journal of Earth Sciences,

$3 \quad$ 51: $927-942$.

4

5 Henderson, J.F. 1949. Pitchblende occurrences between Beaverlodge and Hottah lakes,

6 Northwest Territories. Geological Survey of Canada, Paper 49-16.

8 Hildebrand, R.S. 1981. Early Proterozoic LaBine Group of Wopmay orogen: Remnant of a

9 continental volcanic arc developed during oblique convergence, Edited by F.HA. Campbell.

10 Proterozoic Basins of Canada. Geological Survey of Canada, Paper 81-10, pp. 133-156.

12 Hildebrand, R.S. 1984. Geology of the Rainy Lake - White Eagle Falls area, District of

13 Mackenzie: Early Proterozoic cauldrons, stratovolcanoes and subvolcanic plutons. Geological

14 Survey of Canada, Paper 83-20, 42 p.

16 Hildebrand, R.S. 1985. Geology, Rainy Lake - White Eagle Falls, District of Mackenzie.

17 Geological Survey of Canada, Map 1589A, scale 1:50 000.

19 Hildebrand, R.S., and Roots, C.F. 1985. Geology of the Rivière Grandin map area Hottah terrane

20 and western Great Bear magmatic zone, District of Mackenzie. Geological Survey of Canada,

21 Paper 85-01A, p. 373-383. 
1 Hildebrand, R.S., Bowring, S.A., Steer, M.E., and Van Schmus, W.R. 1983. Geology and U-Pb

2 geochronology of parts of the Leith Peninsula and Rivière Grandin map Areas, District of

3 Mackenzie. Geological Survey of Canada, Paper 83-01A, pp. 329-342.

4

5 Hildebrand, R.S., Annesley, I.R., Bardoux, M.V., Davis, W.J., Heon, D., Reichenbach, I.G., and

6 van Nostrand, T. 1984. Geology of the early Proterozoic rocks in parts of the Leith Peninsula

7 map area, District of Mackenzie. Geological Survey of Canada, Paper 84-01A, pp. 217-221.

9 Hildebrand, R.S., Hoffman, P.F., and Bowring, S.A. 1987a. Tectonomagmatic evolution of the

$101.9 \mathrm{Ga}$ Great Bear magmatic zone, Wopmay orogen, northwestern Canada. Journal of

11 Volcanology and Geothermal Research, 32: 99-118.

12

13 Hildebrand, R.S., Bowring, S.A., Andrew, K.P.E., Gibbins, S.F., and Squires, G.C. $1987 b$.

14 Geological investigations in Calder River map area, central Wopmay orogen, District of

15 Mackenzie. Geological Survey of Canada, Paper 87-1A, pp. 699-711.

16

17 Hildebrand, R.S., Paul, D. Pietikäinen, P., Hoffman, P.F., Bowring, S.A., and Housh, T. 1991.

18 New geological developments in the internal zone of Wopmay orogen, District of Mackenzie:

19 Geological Survey of Canada, Paper 91-1C, pp. 157-164.

20

21 Hildebrand, R.S., Hoffman, P.F., and Bowring, S.A. 2010a. The Calderian orogeny in Wopmay

22 orogen $(1.9 \mathrm{Ga})$, northwestern Canadian Shield. Geological Society of America Bulletin, 122:

23 794-814. 
2 Hildebrand, R.S., Hoffman, P.F., Housh, T., and Bowring, S.A. 2010b. The nature of volcano-

3 plutonic relations and the shapes of epizonal plutons of continental arcs as revealed in the Great

4 Bear magmatic zone, northwestern Canada. Geosphere, 6: 812-839.

5

6 Hoffman, P.F. 1973. Evolution of an early Proterozoic continental margin: the Coronation

7 geosyncline and associated aulacogens, northwest Canadian shield, Edited by J. Sutton and J.F.

8 Windley. Evolution of the Precambrian Crust, Philosophical Transactions of the Royal Society,

9 London, Series A, 273: 547-581.

11 Hoffman, P.F. 1978. Sloan River map area (86K), District of Mackenzie. Geological Survey of

12 Canada, Open File 535, 1 map.

14 Hoffman, P.F. 1980. Wopmay Orogen: a Wilson cycle of Early Proterozoic age in the northwest 15 of the Canadian Shield, Edited by D.W. Strangway. The Continental Crust and its Mineral

16 Deposits. Geological Association of Canada, Special Paper 20, pp. 523-549.

18 Hoffman, P.F. 1984. Geology, Internides of Wopmay orogen, District of Mackenzie, Northwest

19 Territories. Geological Survey of Canada, Map 1576A, scale 1:250 000.

21 Hoffman, P.F. 1987. Continental transform tectonics: Great Slave Lake shear zone (ca. 1.9 Ga),

22 northwest Canada. Geology, 15: 785-788. 
1 Hoffman, P.F. 1988a. United Plates of America, the birth of a craton: Early Proterozoic assembly

2 and growth of Laurentia. Annual Reviews of Earth and Planetary Science, 16: 543-603.

4 Hoffman, P.F. 1988b. East Arm of Great Slave Lake, Northwest Territories. Geological Survey 5 of Canada, Map 1628A, scale 1:250 000.

6

7 Hoffman, P.F. 2012. The tooth of time: how do passive margins become active? Geoscience

8 Canada, 39: 67-73.

10 Hoffman, P.F., and Bowring, S.A. 1984. Short-lived 1.9 Ga continental margin and its

11 destruction, Wopmay Orogen, northwest Canada: Geology, 12: 68-72.

12

13 Hoffman, P.F., and McGlynn, J.C. 1977. Great Bear batholith: a volcano-plutonic depression,

14 Edited by W.R.A. Baragar, L.C. Coleman, and J.M. Hall. Volcanic Regimes of Canada.

15 Geological Association of Canada, Special Paper 16, pp. 169-192.

16

17 Hoffman, P.F., Bell, I.R., and Tirrul, R. 1976. Sloan River map-area (86K), Great Bear Lake, 18 District of Mackenzie. Geological Survey of Canada, Paper 76-1A, pp. 353-358.

20 Hoffman, P.F., Bowring, S.A., Buchwaldt, R., and Hildebrand, R.S. 2011. Birthdate for the 21 Coronation paleocean: age of initial rifting in Wopmay orogen, Canada. Canadian Journal of 22 Earth Sciences, 48: 281-293. 
1 Housh, R., Bowring, S.A., and Villeneuve, M. 1989. Lead isotopic study of early Proterozoic

2 Wopmay orogen, NW Canada: role of continental crust in arc magmatism. The Journal of

3 Geology, 97: 735-747.

4

5 Irvine, E., Baker, J., Hamilton, M., and Wynne, P.J., 2004. Early Proterozoic geomagnetic field

6 in western Laurentia: implications for paleolatitudes, local rotations and stratigraphy.

7 Precambrian Research, 129: 251-270.

8

9 Jackson, V.A. 2008. Preliminary geologic map of part of the southern Wopmay orogen (parts of

10 NTS 86B and 86C; 2007 updates); descriptive notes to accompany 1:100,000 scale map.

11 Northwest Territories Geological Survey, NWT Open Report 2008-007, 53 p., 1 map, scale

$12 \quad 1: 100$ 000. www.nwtgeoscience.ca

13

14 Jackson, V.A., and Ootes, L. 2012. Preliminary geologic map of the south-central Wopmay

15 orogen (parts of NTS 86B, 86C, and 86D); results from 2009 to 2011: Northwest Territories

16 Geological Survey, NWT Open Report 2012-004, 1 map, scale 1:100 000.

17 www.nwtgeoscience.ca

18

19 Jackson V.A., Bennett V., and Irwin, D. 2006. An ArcView 3.x Digital Geological Atlas of the

20 Snare River Area, parts of NTS $85 \mathrm{O}$ and 85N: Northwest Territories Geological Survey, NWT

21 Open File 2006-06, 1 map and digital files. www.nwtgeoscience.ca 
1 Jackson, V.A., van Breemen, O., Ootes, L., Bleeker, W., Bennett, V., Davis, W.J., Ketchum, J.,

2 and Smar, L. 2013. U-Pb zircon ages and field relationships of Archean basement and

3 Paleoproterozoic intrusions, south-central Wopmay Orogen, NWT: implications for tectonic

4 assignments. Canadian Journal of Earth Sciences, 50: 979-1006.

5

6 Johnson, B.J. 1990. Stratigraphy and structure of the Early Proterozoic Wilson Island Group,

7 East Arm thrust-fold belt, N.W.T. Canadian Journal of Earth Sciences, 27: 552-569.

9 Jónasson, K. 1994. Rhyolite volcanism in the Krafla central volcano, north-east Iceland. Bulletin 10 of Volcanology, 56: 516-528.

12 Kelemen, P.B., Hanghøj, K., and Greene, A.R. 2004. One view of the geochemistry of

13 subduction-related magmatic arcs, with an emphasis on primitive andesite and lower crust,

14 Edited by H.D. Holland and K.K. Turekian, Treatise on Geochemistry, Edited by R.L. Rudnick.

15 Volume 3 The Crust. Elsevier - Permagon, Oxford, pp. 85-122

16

17 Kerans, C., Ross, G.M., Donaldson, J.A., and Geldsetzer, H.H.J. 1981. Tectonism and

18 depositional history of the Helikian Hornby Bay and Dismal Lake groups, District of Mackenzie,

19 Edited by F.H.A. Campbell. Proterozoic Basins of Canada. Geological Survey of Canada, Paper

$20 \quad 81-10$, pp. 157-182. 
1 King, J.E. 1987. The metamorphic internal zone of the Wopmay Orogen [Early Proterozoic],

2 Canada: $30 \mathrm{Km}$ of structural relief in a composite section based on plunge projection. Tectonics,

3 5: 973-994.

4

5 Krogh, T.E. 1982. Improved accuracy of U-Pb ages by the creation of more concordant systems

6 using an air abrasion technique. Geochimica et Cosmochimica Acta, 46: 637-649.

7

8 Lalonde, A.E. 1989. Hepburn Intrusive Suite: peraluminous plutonism within a closing back-arc

9 basin, Wopmay orogen, Canada. Geology, 17: 261-264.

10

11 Ludwig, K.R. 2003. User's manual for Isoplot/Ex rev. 3.00: A Geochronological Toolkit for

12 Microsoft Excel. Berkeley Geochronology Center, Berkeley, California, Special Publication 4, $1370 \mathrm{p}$.

14

15 Maniar, P.D., and Piccoli, P.M. 1989. Tectonic discrimination of granitoids. Geological Society

16 of America Bulletin, 101: 635-643.

17

18 Mattinson, J.M. 2005. Zircon U-Pb chemical abrasion (“CA-TIMS”) method: Combined

19 annealing and multi-step partial dissolution analysis for improved precision and accuracy of

20 zircon ages. Chemical Geology, 220: 47-66.

21

22 McGlynn, J.C. 1976. Geology of the Calder River (86F) and Leith Peninsula (86E) map-areas,

23 District of Mackenzie. Geological Survey of Canada, Paper 76-1A, pp. 359-366. 
2 McGlynn, J.C. 1979. Geology of the Precambrian rocks of the Riviere Grandin and in part of the 3 Marian River map areas, District of Mackenzie. Geological Survey of Canada, Paper 79-01A, pp. $4 \quad 127-131$.

6 Moulton, B.J.A., Fowler, A.D., Ayer, J.A., Berger, B.R., and Mercier-Langevin, P. 2011.

7 Archean subqueous high-silica rhyolite coulees: examples from the Kidd-Munro assemblage in 8 the Abitibi Subprovince. Precambrian Research, 189: 389-403.

10 Nicholson, H., Condomines, M., Fitton, J.G., Fallick, A.E., Gronvold, K., and Rogers, G. 1991.

11 Geochemical and isotopic evidence for crustal assimilation beneath Krafla, Iceland. Journal of

12 Petrology, 32: 1005-1020.

14 Ootes, L., Goff, S., Jackson, V.A., Gleeson, S.A., Creaser, R.A., Samson, I.M., Evensen, N.,

15 Corriveau, L., and Mumin, A.H. 2010. Timing and thermochemical constraints on multi-element

16 mineralization at the Nori/RA Cu-Mo-U prospect, Great Bear magmatic zone, Northwest

17 Territories, Canada. Mineralium Deposita, 45: 549-566.

19 Ootes, L., Harris, J., Jackson, V.A., Azar, B., and Corriveau, L. 2013. Uranium-enriched bedrock

20 in the central Wopmay orogen: implications for uranium mineralization. Exploration and Mining 21 Geology, 21: 85-103. 
1 Oueity, J., and Clowes, R.M. 2010. Paleoproterozoic subduction in northwestern Canada from

2 near-vertical and wide-angle seismic reflection data: Canadian Journal of Earth Sciences, 47: 35 -

352.

4

5 Parrish, R.R., Roddick, J.C., Loveridge, W.D., and Sullivan, R.W. 1987. Uranium-lead analytical

6 techniques at the geochronology laboratory, Geological Survey of Canada. Geological Survey of

7 Canada, Paper 87-2, pp. 3-7.

9 Pearce, J.A. 1982. Trace element characteristics of lavas from destructive plate boundaries,

10 Edited by R.S. Thorpe. Andesites. New York, John Wiley and Sons, pp. 525-548.

12 Pearce, J.A. 1996. A user's guide to basalt discrimination diagrams, Edited by D.A. Wyman.

13 Trace Element Geochemistry of Volcanic Rocks; Applications for Massive Sulphide

14 Exploration. Geological Association of Canada, Short Course Notes Volume 12, pp. 79-113.

16 Pearce, J.A., and Cann, J.R. 1973. Tectonic setting of basic volcanic rocks determined using

17 trace element analyses. Earth and Planetary Science Letters, 19: 290-300.

19 Pearce, J.A., and Norry, M.J. 1979. Petrogenetic implications of Ti, Zr, Y, and Nb variations in

20 volcanic rocks. Contributions to Mineralogy and Petrology, 69: 33-47.

22 Pearce, J.A., Harris, N.B.W., and Tindle, A.G. 1984. Trace element discrimination diagrams for

23 the tectonic interpretation of granitic rocks. Journal of Petrology, 25: 956-983. 
2 Pilet, S., Hernandez, J., Bussy, F., and Sylvester, P.J. 2004. Short-term metasomatic control of $3 \mathrm{Nb} / \mathrm{Th}$ ratios in the mantle sources of intraplate basalts. Geology, 32: 113-116.

4

5 Pilkington, M., Miles, W.F., Ross, G.M., and Roest, W.R. 2000. Potential-field signatures of 6 buried Precambrian basement in the Western Canada Sedimentary Basin. Canadian Journal of $7 \quad$ Earth Sciences, 37: 1453-1471.

9 Regan, M.K., Ishizuka, O., Stern, R.J., Kelley, K.A., Ohara, Y., Blichert-Toft, J., Bloomer, S.H.,

10 Cash, J., Fryer, P., Hanan, B.B., Hickey-Varga, R., Ishii, T., Kimura, J-I., Peate, D.W., Rowe,

11 M.C., and Wodds, M. 2010. Fore-arc basalts and subduction initiation in the Izu-Bonin -

12 Mariana system. G3 Geochemistry, Geophysics, and Geosystems, 11: Q03X12,

13 doi:10.1029/2009GC002871.

14

15 Reichenbach, I.G. 1991. The Bell Island Bay Group, remnant of an early Proterozoic ensialic 16 marginal basin in Wopmay orogen, District of Mackenzie. Geological Survey of Canada, Paper $17 \quad 88-28,43 \mathrm{p}$.

19 Richard, P., Shimizu, N., and Allègre, C.J. $1976 .{ }^{143} \mathrm{Nd} /{ }^{146} \mathrm{Nd}$, a natural tracer: an application to 20 oceanic basalts. Earth and Planetary Science Letters, 31: 269-278.

22 Roddick, J.C. 1987. Generalized numerical error analysis with applications to geochronology 23 and thermodynamics. Geochimica et Cosmochimica Acta, 51: 2129-2135. 
2 Ross, G.M. 2002. Evolution of Precambrian continental lithosphere in western Canada: results

3 from Lithoprobe studies in Alberta and beyond. Canadian Journal of Earth Sciences, 39: 413-

4437.

5

6 Shakotko, P., Ootes, L., and Pan, Y, 2012. Behavior of accessory minerals during

7 Paleoproterozoic (1.9 Ga) weathering processes, Beaverlodge Ridge, NWT, Canada.

$8 \quad$ Mineralogical Magazine, 76: 2356.

9

10 Shervais, J.W. 1982. Ti-V plots and the petrogenesis of modern and ophiolitic lavas. Earth and

11 Planetary Science Letters, 59: 101-118.

12

13 Shervais, J.W. 2001. Birth, death, and resurrection: the life cycle of the suprasubduction zone

14 ophiolites. G3, Geochemistry, Geophysics, Geosystems, 2: 2000 GC000080.

16 Spratt, J.E., Jones, A.G., Jackson, V.A., Collins, L., and Avdeeva, A. 2009. Lithospheric

17 geometry of the Wopmay orogen from a Slave craton to Bear Province magnetotelluric transect.

18 Journal of Geophysical Research, 114: B01101.

20 Stern, R.A. 1997. The GSC Sensitive High Resolution Ion Micro Probe (SHRIMP): analytical

21 techniques of zircon $\mathrm{U}-\mathrm{Th}-\mathrm{Pb}$ age determinations and performance evaluation. Geological

22 Survey of Canada, Current Research 1997-F, pp.1-31. 
1 Stern, R.A., and Amelin, Y. 2003. Assessment of errors in SIMS zircon U-Pb geochronology

2 using a natural zircon standard and NIST SRM 610 glass. Chemical Geology, 197: 111-146.

4 St-Onge, M.R., and King, J.E. 1986. Evolution of regional metamorphism during back-arc

5 stretching and subsequent crustal shortening in the $1.9 \mathrm{Ga}$ Wopmay orogen, Canada.

6 Philisophical Transactions of the Royal Society of London, A, 321: 199-218.

8 St-Onge, M.R., and King, J.E. 1987. Thermo-tectonic evolution of a metamorphic internal zone

9 documented by axial projections and petrological P-T paths, Wopmay orogen, northwest Canada.

10 Geology, 15: 155-158.

12 St-Onge, M.R., Lalonde, A.E., and King, J.E. 1983. Geology, Redrock Lake and eastern Calder

13 River map areas, District of Mackenzie: the central Wopmay Orogen (early Proterozoic), Bear

14 Province, and the western Archean Slave Province. Geological Survey of Canada, paper 83-1A, 15 pp. 147-152.

16

17 St-Onge, M.R., King, J.E., and Lalonde, A.E., 1991. Geology, east-central Wopmay orogen,

18 District of Mackenzie, Northwest Territories. Geological Survey of Canada, Map 1754A, scale

$191: 125000$.

21 Sun, S.S., and McDonough, W.F. 1989. Chemical and isotopic systematics of oceanic basalts:

22 implications for mantle composition and processes, Edited by A.D. Saunders and M.J. Norry. 
1 Magmatism in the Ocean Basins. Geological Society of London, Special Publication, 42, pp.

$2 \quad 313-345$.

3

4 Sutherland, F.H., Kent, G.M., Harding, A.J., Umhoefer, P.J., Driscoll, N.W., Lizarralde, D.,

5 Fletcher, J.M., Axen, G.J., Holbrook, W.S., González-Fernández, A., and Lonsdale, P. 2012.

6 Middle Miocene to early Pliocene oblique extension in the southern Gulf of California.

7 Geosphere, 8: 752-770.

8

9 Thorkelson, D.J., Madsen, J.K., and Sluggett, C.L. 2011. Mantle flow through the northern

10 Cordilleran slab window revealed by volcanic geochemistry. Geology, 39: 267-270.

11

12 Trop, J.M., Hart, W.K., Snyder, D., and Idleman, B. 2012. Miocene basin development and

13 volcanism along a strike-slip to flat-slab subduction transition: Stratigraphy, geochemistry, and

14 geochronology of the central Wrangell volcanic belt, Yakutat-North America collision zone.

15 Geosphere, 8: 805-834.

16

17 Umhoefer, P.J. 2011. Why did the southern Gulf of California rupture so rapidly? Oblique

18 divergence across hot, weak lithosphere along a tectonically active margin. GSA Today, 21: 4-

1910.

20

21 van Breemen, O., and Henderson, J.B. 1988. U-Pb zircon and monazite ages from the eastern

22 Slave Province and Thelon Tectonic Zone, Artillery Lake, N.W.T. Geological Survey of Canada,

23 Paper 88-2, pp. 73-83. 
2 Villeneuve, M.E., Ross, G.M., Thériault, R.J., Miles, W., Parrish, R.R., and Broome, J. 1993.

3 Tectonic subdivision and $\mathrm{U}-\mathrm{Pb}$ geochronology of the crystalline basement of the Alberta Basin,

4 western Canada: Geological Survey of Canada, Bulletin 447, 86 p.

5

6 Villeneuve, M.E., Thériault, R.J., and Ross, G.M. 1991. U-Pb ages and Sm-Nd signature of two

7 subsurface granites from the Fort Simpson magnetic high, northwest Canada. Canadian Journal

8 of Earth Sciences, 28: 1003-1008.

10 Wallace, L.M., Barnes, P., Beavan, J., Van Dissen, R., Litchfield, N, Mountjoy, J., Langridge,

11 R., Lamarche, G., Pondard, N. 2012. The kinematics of a transition from subduction to strike-

12 slip: An example from the central New Zealand plate boundary. Journal of Geophysical

13 Research, 117: B02405.

14

15 Williams, R.M.E., Grotzinger, J.P, 36 others, and MSL Science Team 2013. Martian fluvial

16 conglomerates at Gale Crater. Science, 340: 1068-1072.

18 Wilson, A., 1979, Petrology and geochemistry of the upper Hottah Lake sequence, Hottah Lake,

19 District of Mackenzie, NWT. Unpublished B.Sc. thesis, McMaster University, 88 p.

21 Winchester, J.A., and Floyd, P.A. 1977. Geochemical discrimination of different magma series

22 and their differentiation products using immobile elements. Chemical Geology, 20: 325-343. 
1 Wood, D.A. 1980. The application of a Th-Hf-Ta diagram to problems of tectonomagmatic

2 classification and to establishing the nature of crustal contamination of basaltic lavas of the

3 British Tertiary Volcanic Province. Earth and Planetary Science Letters, 50: 11-30.

4

5 Wu, X., Ferguson, I.J., and Jones, A.G. 2005. Geoelectric structure of the Proterozoic Wopmay

6 Orogen and adjacent terranes, Northwest Territories, Canada. Canadian Journal of Earth

7 Sciences, 42: 955-981.

8

9 Yamashita, K., Creaser, R.A., Stemler, J.U., and Zimaro, T.W. 1999. Geochemical and Nd-Pb

10 isotopic systematics of late Archean granitoids, southwestern Slave Province, Canada:

11 Constraints for granitoid origin and crustal isotopic structure. Canadian Journal of Earth

12 Sciences, 36: 1131-1147. 


\section{Figure Captions}

3 Figure 1. A) Tectonic subdivisions of the western Canadian Shield (Modified after Hoffman 4 1988; Villeneuve et al. 1993; Ross 2002; Aspler et al. 2003). Solid thick black line between

5 Great Bear Lake and western Saskatchewan demarcates the eastern edge of the Phanerozoic 6 platformal cover. Grey solid lines represent major faults. Blue line is the seismic line. B)

7 Composite block diagram comprising the interpreted seismic section (vertical section; modified

8 from Cook and Erdmer 2005) and interpreted domain subdivisions (horizontal plane; modified

9 from Aspler et al. 2003). Blue line (also shown in Fig. 1A) represents seismic line.

11 Figure 2. A) Geological map of the western Wopmay orogen. Locations are DeVries Lake (DL),

12 Grant Lake (GL), Ham Lake (HL), Leith Ridge (LR), Rebesca Lake (RL), Swan Lake (SL),

13 Treasure Lake Group (TLG; this is the type section of Gandhi and van Breemen, 2005), and

14 Zebulon River (ZR). B) Geological map of exposed rocks assigned to Hottah terrane, including

15 units of the Bell Island Bay Group, and supracrustal rocks of the younger Great Bear magmatic

16 zone (GBMZ). Arrows point to sample locations discussed in text; Beaverlodge Lake andesite

17 (BLa), Hottah plutonic complex plagioclase-quartz porphyry (Hp), Hottah plutonic complex K-

18 feldspar phenocrystic granite $(\mathrm{Hg})$, Hottah plutonic complex tonalite $(\mathrm{Ht})$, Stairs Bay rhyolite

19 (SBr), and Zebulon Formation rhyolite (Zr). Modified after Henderson (1949), McGlynn (1979),

20 Hildebrand and Roots (1985), Reichenbach (1991), Hoffman and Hall (1992), and Jackson and

21 Ootes (2012).

23 Figure 3. Previously proposed tectonic models for the evolution of the Hottah terrane and

24 Wopmay orogen. A) Hottah terrane as an exotic arc and micro-continent that collided with the

25 western Slave craton at ca. $1880 \mathrm{Ma}$ (modified after Bowring and Grotzinger 1992). B) Hottah

26 terrane developed as a ca. 1940-1885 Ma arc that was separated from Slave craton by a back-arc

27 basin (modified after Reichenbach 1991; Bowring and Grotzinger 1992). HIS - Hepburn

28 Intrusive Suite; MIZ - Metamorphic internal zone; TK - Turmoil klippe; WFZ - Wopmay fault

29 zone. 
1 Figure 4. Outcrop photographs of selected units discussed in this paper. A) Holly Lake

2 metamorphic complex migmatitic semipelites (Ms) cross-cut by granodiorite (Gr) and younger

3 pegmatite (P) dykes at Leith ridge (Fig. 2). Inset photograph shows compositional layering

4 (dashed white line), likely primary, in migmatized semi-pelite that is cut by quartz vein that was

5 later boudinaged. B) Complex intrusive breccia of Hottah plutonic complex, including early

6 gabbro (Gab), diorite (Drt), and a youngest phase of granodiorite (Grdt), near sample location $\mathrm{Ht}$

7 (Fig. 2B). C) Unconformity (dashed white line) between Beaverlodge Lake sandstone and

8 underlying Hottah plutonic complex, east side of Bell Island (Fig. 2B). Symbols: flat lying,

9 upright-facing bedding in the coarse conglomerate on top (white barbed symbol) are at a high

10 angle to moderately developed foliation, defined by feldspar and micas, in the underlying granite

11 (black foliation symbol). D) Coarsely spherulitic (S) rhyolite with quartz-filled lithophysae (L)

12 of the Zebulon Formation at sample location Zr (Fig. 2B, 5E; Table 1). E) Unconformities at

13 Beaverlodge Lake where Zebulon Formation (ZF) overlies Hottah plutonic complex plagioclase-

14 quartz porphyry and quartz arenite of the Conjuror Bay Formation (CBF) overlies both units.

15 Dashed white lines depict unconformities. White diamond is U-Pb sample location of Hottah

16 plagioclase-quartz porphyry (Hp; Fig. 2B, 5B; Table 1); black diamond is detrital zircon sample

17 location of Conjuror Bay Formation quartz arenite (Davis et al. submitted). View is to the north,

18 person for scale is circled. Inset shows unconformity of quartz arenite on heavily altered Hottah

19 porphyry with blocks of altered porphyry at the base of quartz arenite. Hammer for scale

20 (circled). F) Moderately flattened fiamme-bearing rhyolitic ignimbrite from Swan Lake at

21 sample location SL (Fig. 2A, 5J; Table 1). E) Quartz and feldspar crystal-rich rhyolite from

22 Stairs Bay, southeast Hottah Lake at sample location SBr (Fig. 2B, 5L; Table 1).

24 Figure 5. Concordia diagrams of the U-Pb zircon results using TIMS (A-L) and SHRIMP (M).

25 A) Hottah plutonic complex K-feldspar porphyritic granite, B) quartz-plagioclase porphyry, C)

26 strongly deformed granodiorite, D) tonalite, E) Zebulon Formation spherulitic rhyolite, F) Bloom

27 rhyodacite, G) Grant Subgroup rhyodacite, H) Great Bear magmatic zone rhyolitic ash tuff, I)

28 Beaverlodge Lake fragmental andesite, J) Swan Lake rhyolitic ignimbrite, K) deformed

29 honrblende-biotite granodiorite, L) Stairs Bay rhyolitic quartz-feldspar crystal tuff. M) SHRIMP

$30 \mathrm{U}-\mathrm{Pb}$ zircon results from Dumas Group rhyodacite. Data-point error ellipses are $2 \sigma$. Results are

31 in Tables 1 and 2 and analytical techniques are in Appendix I. 
2 Figure 6. $\varepsilon \mathrm{Nd}^{\mathrm{T}}$ versus Age (Ma) plot. The data from Bowring and Podosek (1989) only includes

3 samples from west of Wopmay fault zone. Data from the Fort Simpson terrane granites are from

4 Villeneuve et al. (1991). The Slave array is projected from 2.6 to 2.58 Ga granites in the

5 southwestern Slave craton (Yamashita et al. 1999) and any older or more evolved Slave

6 granitoids would project below this array. Upper boundary on the Depleted mantle is from

7 Goldstein et al. (1984) and the lower boundary from DePaolo (1981).

Figure 7. Stratigraphy of the Hottah terrane - Great Bear volcano-plutonic continuum (no vertical scale implied). Age determinations are in $\mathrm{Ma}( \pm 2 \sigma$ uncertainty); Great Bear plutonic

11 ages are not shown. Previously reported ages are italicized and from Bowring (1984),

12 Reichenbach (1991), Gandhi et al. (2001), and Bennett and Rivers (2006a). The detrital zircon

13 (DZ) maximum depositional ages for the Holly Lake metamorphic complex are from Davis et al.

14 (submitted) and the Treasure Lake Group are from Gandhi and van Breemen (2005) and Bennett

15 and Rivers (2006b). For Archean basement ages see Jackson et al. (2013) and Bowring (1984).

17 Figure 8. Geochemical plots. A) $\mathrm{CaO}+\mathrm{Na}_{2} \mathrm{O}-\mathrm{Al}_{2} \mathrm{O}_{3}-\mathrm{K}_{2} \mathrm{O}$, or chemical index of alteration

18 (CIA) plot of Hottah plutonic complex and Zebulon Formation demonstrating the aluminium and

19 potassium enrichment of the units relative to 'typical' unaltered end-member examples (open

20 circles). B) Maniar and Piccoli (1989) plot to illustrate that Zebulon Formation rhyolites and

21 some Hottah plutonic complex samples fall on a 'mixing line', interpreted as a result of alteration

22 of the mobile major elements. C) Immobile trace element ratio diagram with all units in this

23 study plotted. This diagram is preferred over the total alkali - silica diagram because the alkali

24 elements in the Zebulon Formation and some Hottah plutonic complex samples have been

25 compromised due to alteration (see Fig. 8A-B). Diagram from Pearce (1996) and modified after

26 Winchester and Floyd (1977). D) $\mathrm{Zr}-\mathrm{TiO}_{2}$ plot. Lines are 20\% increment end-member mixing

27 trends (denoted by points on line). Dashed line is Bloom-Grant basalts. Two end-member mixing

28 lines are shown for Zebulon Formation basalts and basaltic andesites, and one for Zebulon

29 Formation rhyolite samples. Grey shaded area denotes distinct high-Zr dacite-andesite-trachyte

30 samples. E) Immobile trace element ratio versus $\mathrm{SiO}_{2}$ (Winchester and Floyd, 1977) for all

31 Zebulon Formation samples. Some of the samples plot as andesites but are better termed 
1 andesitic basalt as they may be enriched in $\mathrm{SiO}_{2}$ either from alteration, or incorporation of

2 amygdales (see Figure 4C). Samples plotted include those from this study and from Reichenbach

3 (1991). Analytical techniques are in Appendix I and Table A1. Relevant geochemical features

4 are summarized in Table 3. See text for further discussion.

Figure 9. Chondrite and Primitive Mantle-normalized plots (Sun and McDonough 1989).

7 Symbols as in Figure 8. A) Hottah plutonic complex. Vertical grey bars in Primitive Mantle-

8 normalized diagram indicate those elements suspected to be mobile during alteration and are

9 removed from the subsequent plots (Rb, Ba, U, K, Sr). Circa 1913 Ma tonalite (Ht) and ca. 1930

10 Ma granite and feldspar-quartz porphyry (Hg-Hp). B) Zebulon Formation rhyolite. Pleistocene

11 Long Valley Caldera data are from Moulton et al. (2011). C) Zebulon Formation basalt. D)

12 Bloom Basalt (squares) and Grant Subgroup basalt (circles). Closed circles are samples from

13 north of Grant Lake (GL) and open circles are from samples north of Rebesca Lake (RL; Fig.

14 2A). Heavy dashed grey line on Primitive Mantle-normalized plot is Zebulon Formation basalt

15 for comparison. E) Bloom rhyodacite and Grant Subgroup rhyodacite. Heavy solid black line on

16 Primitive Mantle normalized plot is Bloom Basalt for comparison. F) Great Bear magmatic zone

17 volcanic rocks, including ca. $1873 \mathrm{Ma} \mathrm{LaBine} \mathrm{Group} \mathrm{andesite} \mathrm{(BLa)} \mathrm{from} \mathrm{the} \mathrm{Beaverlodge} \mathrm{Lake}$

18 area, ca. 1862 Ma Sloan Group basalt (SBr-b) and rhyolite (SBr) from the Stairs Bay area, ca.

191869 Ma Faber Group ignimbrite (SL) from the Swan Lake area (Fig. 2). Grey shaded band is

20 andesitic to rhyolitic volcanic rocks and intrusive porphyries from the Fab Lake area $(n=26$; Azar

21 2007). All other samples plotted are from this study.

23 Figure 10. Tectonic discrimination diagrams. A) Nb-Y plot (Pearce et al. 1984) for Hottah

24 plutonic complex samples and Great Bear (GB) magmatic zone volcanic rocks (includes data

25 from Azar 2007); fields are ocean ridge granite (ORG), volcanic arc granite (VAG), syn-

26 collisional granite (syn-COLG), and within plate granite (WPG). B) V-Ti discrimination diagram

27 for basalts (Shervais 1982); fields are back-arc basin (BAB), mid-ocean ridge basalt (MORB),

28 boninite (BON), island arc tholeiite (IAT), and alkaline basalt. Plot includes Bloom and Zebulon

29 Formation basalt data from Reichenbach (1991). C) Zr-(Ti/100)-(Y*3) discrimination diagram

30 for basalts with $\mathrm{CaO}+\mathrm{MgO} 12-20 \%$ (Pearce and Cann 1973). Fishtrap Lake gabbro data

31 (Reichenbach 1991) and Grant Subgroup basalt data (Type 2 in Easton 1980) are overlapped by 
1 the Bloom-Grant basalt and not visible. Figure includes Bloom and Zebulon Formation basalt 2 data from Reichenbach (1991). D) Th-(Hf/3)-(Nb/16) diagram (after Wood, 1980). Only data

3 from this study are plotted as the data in Reichenbach (1991) does not contain Th values. E)

$4 \mathrm{Th} / \mathrm{Yb}-\mathrm{Ta} / \mathrm{Yb}$ discrimination diagram (after Pearce 1982). Western North America arc

5 (WNAarc) and back-arc basin basalt (BABB) fields from Cole and Stewart (2009), fore-arc

6 basalt (FAB) field from Regan et al. (2010), and ocean island basalt (OIB), enriched-mid-ocean

7 ridge basalt (E-MORB), and normal mid-ocean ridge basalt (N-MORB) from Sun and

8 McDonough (1989).

10 Figure 11. A) Transtensional shear evolution of Baja California and Gulf of California. Baja

11 California began as an arc on the North American plate and was transferred to the Pacific plate

12 during rapid rifting and basin opening in an active margin, over the last $20 \mathrm{Ma}$ (adapted from

13 Bennett et al. 2013). Baja California could move another 500 to $1000 \mathrm{~km}$ northward during the

14 next $20 \mathrm{Ma}$. B) Application of the Baja California model to the 1913 to $1893 \mathrm{Ma}$ evolution of the

15 Hottah terrane rocks, where the Hottah plutonic complex represents the root of a volcanic arc

16 that began on the North American plate (potentially the Taltson or Ksituan magmatic zones to

17 the south) and was dextrally translated off this parental crust during arc rifting and basinal

18 opening. The Hottah plutonic complex was overlain by the Zebulon Formation (ZF) subaerial,

19 rhyolite-dominated volcanism in a rifting arc between ca. 1906 and 1900 Ma. Continued rifting

20 led to drowning of the subaerial volcanic rocks and deposition of the Conjuror Bay Formation

21 (CBF) quartz arenite at ca. 1900 Ma. Further attenuation led to the eruption of the subaqueous

22 Bloom Basalt (BB) in the west and Grant Subgroup (GS) in the east between ca. 1900 and 1893

23 Ma in a either rifted arc or marginal basin setting. In this model transtensional shear related to

24 basinal opening would eventually transfer the Hottah terrane northward along a proto-Wopmay

25 fault, arriving adjacent to the Slave craton at ca. $1880 \mathrm{Ma}$ (not shown). 


\section{Appendix I - Analytical Methods}

$2 \quad \mathrm{U}-\mathrm{Pb}$ Zircon Geochronology

Zircon fractions from 11 samples were prepared using the annealing and chemical leaching technique modified from that described by Mattinson (2005) and isotopic and U-Pb

5 compositional data were determined by isotope dilution thermal ionization mass spectrometry

6 (CA-ID-TIMS) at the Geochronology laboratory, Geological Survey of Canada. Results are tabulated in Table 1 . The samples were annealed at $1000^{\circ} \mathrm{C}$ for 48 hours and then leached for 12-

816 hours, in $\mathrm{HF}_{-} \mathrm{HNO}_{3}$ at $180^{\circ} \mathrm{C}$ in Savillex $3 \mathrm{~mL}$ PFA capsules within a Parr digestion vessel.

9 Zircon fractions from one sample $(09 \mathrm{vj} 171)$ were prepared by mechanical abrasion method of

10 Krogh (1982; Table 1). Sample dissolution and chemical methods are described in Parrish et al.

11 (1987). Individual crystals were selected under binocular microscope to avoid inclusions and 12 other imperfections, spiked with a mixed ${ }^{205} \mathrm{~Pb}_{-}{ }^{233} \mathrm{U}-{ }^{235} \mathrm{U}$ tracer solution calibrated to $\pm 0.1 \%$

13 against a gravimetric solution, and dissolved in high-pressure bombs in $\mathrm{HF}_{-} \mathrm{HNO}_{3}$. Data

14 reduction and error propagation follow methods outlined in Roddick (1987). Uranium and $\mathrm{Pb}$

15 isotopic ratios were measured using a Triton mass spectrometer operated in either static multicollection mode or using a secondary electron multiplier and ion counting system. The ${ }^{205} \mathrm{~Pb}$, ${ }^{206} \mathrm{~Pb},{ }^{207} \mathrm{~Pb}$, and ${ }^{208} \mathrm{~Pb}$ isotopes were measured simultaneously in Faraday collectors, with ${ }^{204} \mathrm{~Pb}$

18 in an axial secondary electron multiplier. Faraday-multiplier gain was monitored and corrected

19 by peak jumping ${ }^{205} \mathrm{~Pb}$ into the axial cup. $\mathrm{A} \mathrm{Pb}$ mass fractionation correction of $0.1 \pm 0.04 \%$ /amu

20 was applied as determined by replicate analyses of the NBS981 standard (Table 1). U

21 fractionation was corrected using the ${ }^{233} \mathrm{U}_{-}{ }^{235} \mathrm{U}$ double spike and was typically in the range of

$220.12 \% / a m u$. Dead time for the ion counting system was determined by replicate analyses of the

23 NBS982 solution. Accuracy and reproducibility of the ion counting measurements were

24 monitored by analyses of the GSC standard 6266 with a ${ }^{206} \mathrm{~Pb} /{ }^{238} \mathrm{U}$ ratio of 0.0963 .

Zircon fractions from one sample (09vj148c) were prepared for sensitive high resolution

26 ion microprobe analysis (SHRIMP II) at the Geological Survey of Canada. Results are tabulated

27 in Table 2. SHRIMP analytical procedures followed those described by Stern (1997). Briefly,

28 zircons were cast in $2.5 \mathrm{~cm}$ diameter epoxy mounts along with fragments of the GSC laboratory

29 standard zircon (z6266, with ${ }^{206} \mathrm{~Pb} /{ }^{238} \mathrm{U}$ age $=559 \mathrm{Ma}$, Stern and Amelin 2003). The mid-

30 sections of the zircons were exposed using 9, 6, and $1 \mu \mathrm{m}$ diamond compound, and the internal

31 features of the zircons (such as zoning, structures, alteration, etc.) were characterized in back- 
1 scattered electron mode (BSE) utilizing a Zeiss Evo 50 scanning electron microscrope. Mount

2 surfaces were evaporatively coated with $10 \mathrm{~nm}$ of high purity Au. Analyses were conducted

3 using an ${ }^{16} \mathrm{O}^{-}$primary beam, projected onto the zircons at $10 \mathrm{kV}$. The count rates at eleven

4 masses including background were sequentially measured over 5 scans with a single electron

5 multiplier and a pulse counting system with deadtime of $23 \mathrm{~ns}$. Off-line data processing was

6 accomplished using SQUID version 2.22. The $1 \sigma$ external errors of ${ }^{206} \mathrm{~Pb} /{ }^{238} \mathrm{U}$ ratios reported in

7 the data table incorporate a minimum $\pm 1.0 \%$ error in calibrating the standard zircon (see Stern

8 and Amelin 2003). Pb isotopic values were monitored by analyses of an in house standard with a

$9{ }^{207} \mathrm{~Pb} /{ }^{206} \mathrm{~Pb}$ age of $2679.6 \pm 0.3 \mathrm{Ma}$ ); a small mass bias correction (1.0029) was applied for

10 samples 10232 and 10320. Common $\mathrm{Pb}$ correction utilized the $\mathrm{Pb}$ composition of the surface

11 blank (Stern 1997). Isoplot v. 3.00 (Ludwig 2003) was used to generate concordia plots and

12 calculate weighted means. The error ellipses on the concordia diagrams (Fig. 5) and the weighted

13 mean errors are reported at $2 \sigma$.

15 Major and Trace-element Geochemistry

16 Major and trace-element geochemistry (Tables 3 and A1) was completed on fresh and clean

17 samples at Acme Analytical labs between January and March 2012. Samples were crushed and

18 pulverized using mild steel. Major and HFSE were analyzed by pressed pellet XRF (Code 4X).

19 For LILE, HFSE, and REE, powdered samples were mixed with Lithium metaborate/tertaborate

20 and fused in a furnace, followed by cooling and dissolving of the bead in nitric acid, and then

21 analyzed by ICP-MS (Code 4B). Gallium values were determined by subjecting the prepared

22 sample powders to a HF-aqua regia leach in a hot water bath, cooling, then analyzing by ICP-ES.

23 For the base and precious metals (including $\mathrm{Pb}$ ) a separated $0.5 \mathrm{~g}$ split was digested in Aqua

24 Regia and analysed by ICP-MS (Code 1DX). International standards were run once for every ten

25 unknowns. Assessment of the data using the pulp and preparation duplicates and in-house and

26 international standards indicates the major element oxides have less than $2 \%$ error, except for

27 oxides with lower concentrations which may have up to 5\% error. High-field strength elements

28 and REE are quoted at better than $10 \%$, although in general are better than $5 \%$, the higher error

29 in relation to lower concentrations of these elements in some samples. Sample location

30 coordinates and mimimum detection limits are in Table A1. 


\section{Samarium-Neodymium(Sm-Nd) Isotope Geochemistry}

Samarium-Neodymium isotopic analyses were completed at Carleton University, Ottawa,

3 ON, Canada between January and March, 2012. Between 100 and $300 \mathrm{mg}$ of powder from each

4 sample was weighed into a screw-cap Teflon vial, to which a mixed ${ }^{148} \mathrm{Nd}-{ }^{149} \mathrm{Sm}$ spike was

5 added. The powder-spike mixture was dissolved in $\mathrm{HNO}_{3}-\mathrm{HF}$, which was further attacked with

$6 \mathrm{HNO}_{3}$ and $\mathrm{HCl}$ until no residue remained visible. The bulk REE was separated using cation

7 chromatography (Dowex 50-X8). The REE-bearing residue was then dissolved in $0.26 \mathrm{~N} \mathrm{HCl}$ and

8 loaded into an Eichrom chromatographic column containing Teflon powder coated with HDEHP

9 [di(2-ethylhexyl)] orthophosphoric acid (Richard et al. 1976). Neodymium was eluted using

$10 \quad 0.26 \mathrm{~N} \mathrm{HCl}$, followed by $\mathrm{Sm}$ in $0.5 \mathrm{~N} \mathrm{HCl}$.

11 Total procedural blanks for $\mathrm{Nd}$ are $<200$ picograms. Concentrations are precise to $\pm 1 \%$,

12 but ${ }^{147} \mathrm{Sm} /{ }^{144} \mathrm{Nd}$ ratios are reproducible to $\pm 0.5 \%$. Samples were loaded with $0.3 \mathrm{~N} \mathrm{H}_{3} \mathrm{PO}_{4}$ on one

13 side of a Re double filament assembly, and run at temperatures of $1750-1800^{\circ} \mathrm{C}$ in a 9-cup

14 ThermoFinnigan TRITON T1 multicollector mass spectrometer. Isotope ratios are normalized to

$15{ }^{146} \mathrm{Nd} /{ }^{144} \mathrm{Nd}=0.72190$. Analyses of the USGS standard $\mathrm{BCR}-1$ yield $\mathrm{Nd}=29.02 \mathrm{ppm}, \mathrm{Sm}=6.68$

$16 \mathrm{ppm}$, and ${ }^{143} \mathrm{Nd} /{ }^{144} \mathrm{Nd}=0.512668 \pm 0.000020(\mathrm{n}=4)$. Over the last two years the La Jolla

17 standard average is ${ }^{143} \mathrm{Nd} /{ }^{144} \mathrm{Nd}=0.511826 \pm 0.000013$. Epsilon values at time $\mathrm{T}$ are calculated

18 using the following relation:

$$
\varepsilon \mathrm{Nd}^{\mathrm{T}}=\left[\left({ }^{143} \mathrm{Nd} /{ }^{144} \mathrm{Nd}_{\text {sample }}{ }^{\mathrm{T}} /{ }^{143} \mathrm{Nd} /{ }^{144} \mathrm{Nd}_{\mathrm{CHUR}}{ }^{\mathrm{T}}\right)-1\right] * 10000
$$

20 where CHUR is the Chondrite Uniform Reservoir and T is the time the rock was formed.

21 Depleted mantle model ages $\mathrm{T}_{\mathrm{DM}}$ ages were calculated for felsic-intermediate rocks with

$22{ }^{147} \mathrm{Sm} /{ }^{144} \mathrm{Nd}<0.1500$ using a modified method of Goldstein et al. (1984) assuming a modern

23 upper mantle with ${ }^{147} \mathrm{Sm} /{ }^{144} \mathrm{Nd}=0.214$ and ${ }^{143} \mathrm{Nd} /{ }^{144} \mathrm{Nd}=0.513115$ (Tables 3 and A2). 


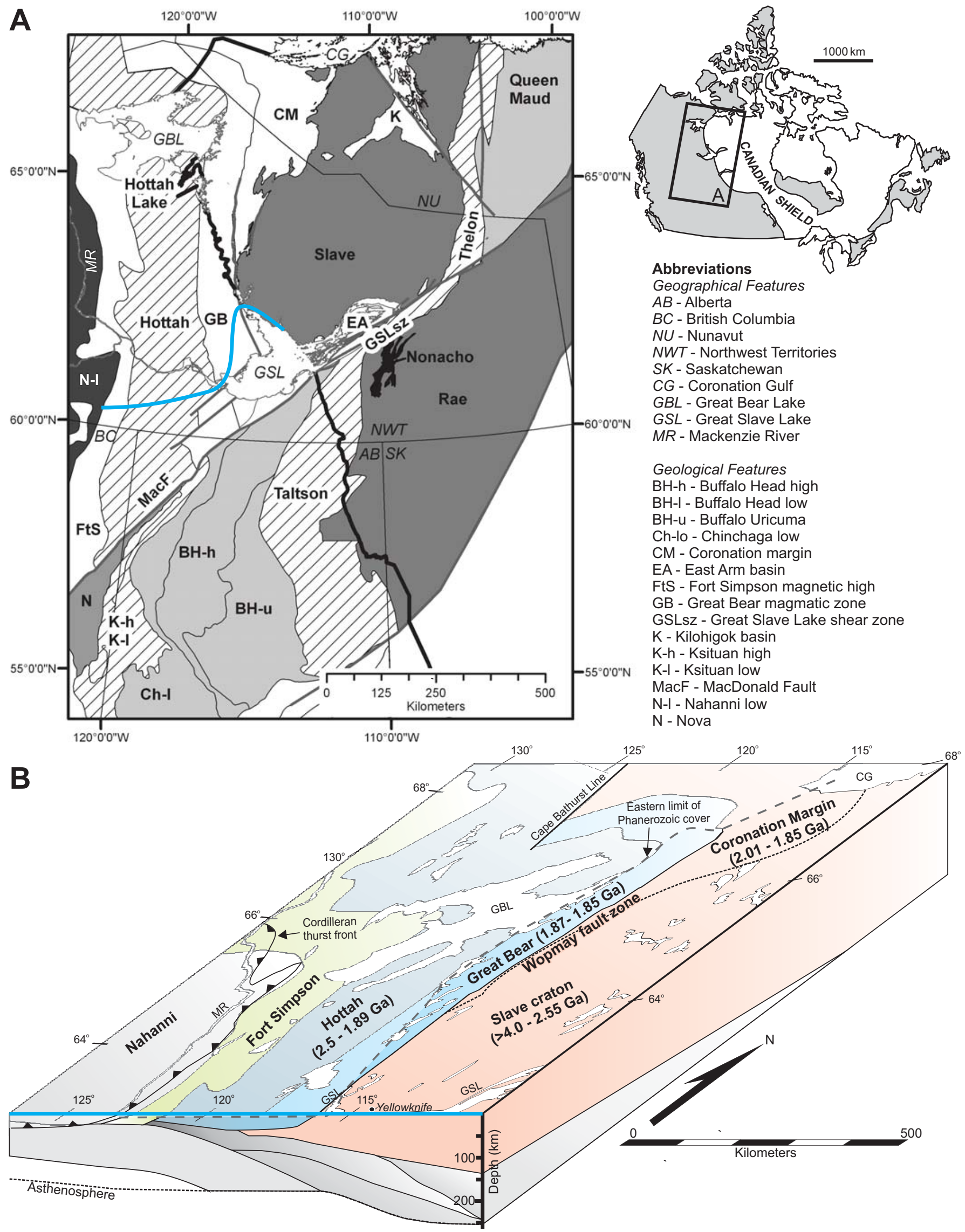

Figure 1. Ootes et al., Hottah Terrane 

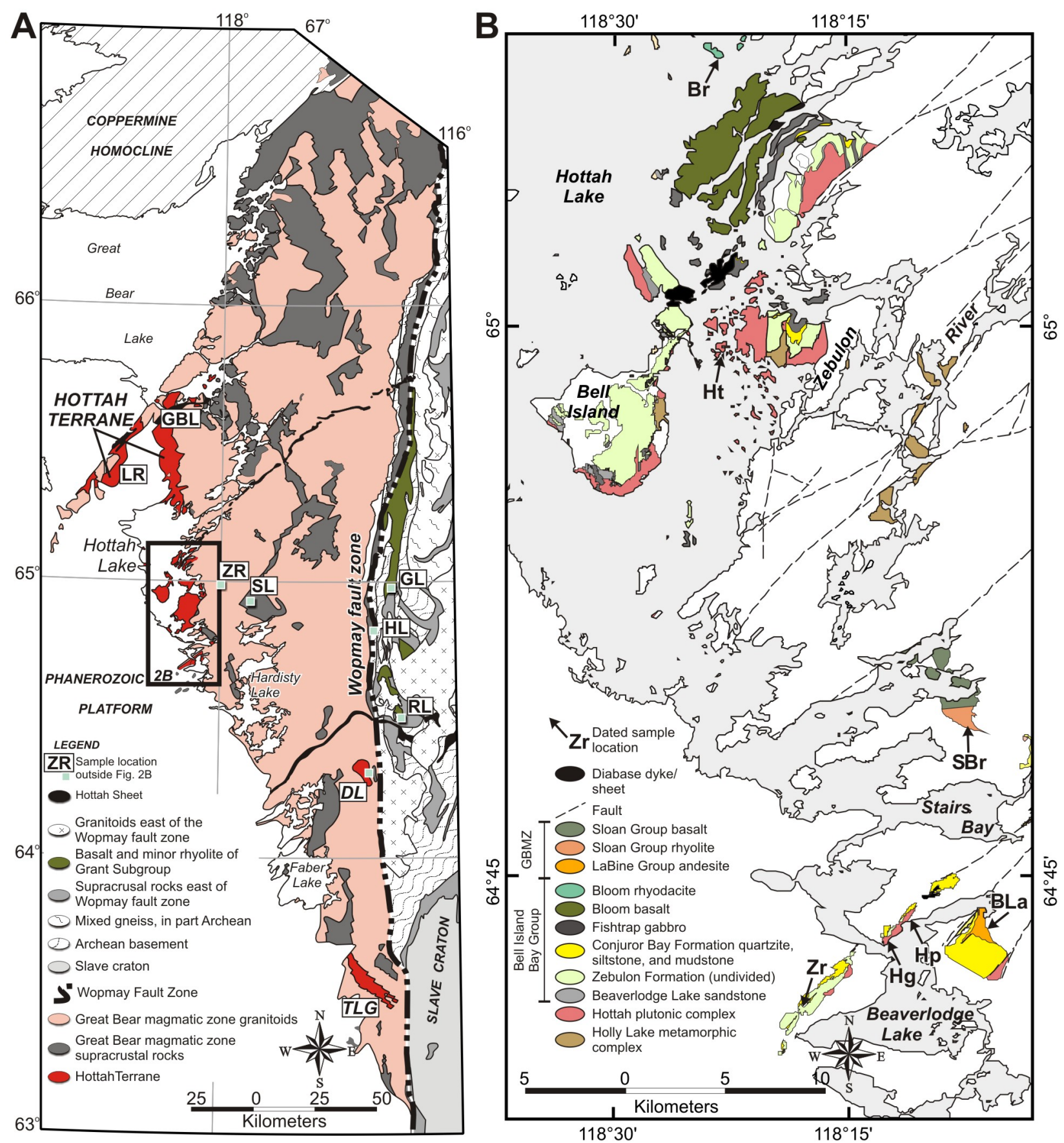

Figure 2: Ootes et al., Hottah Terrane 

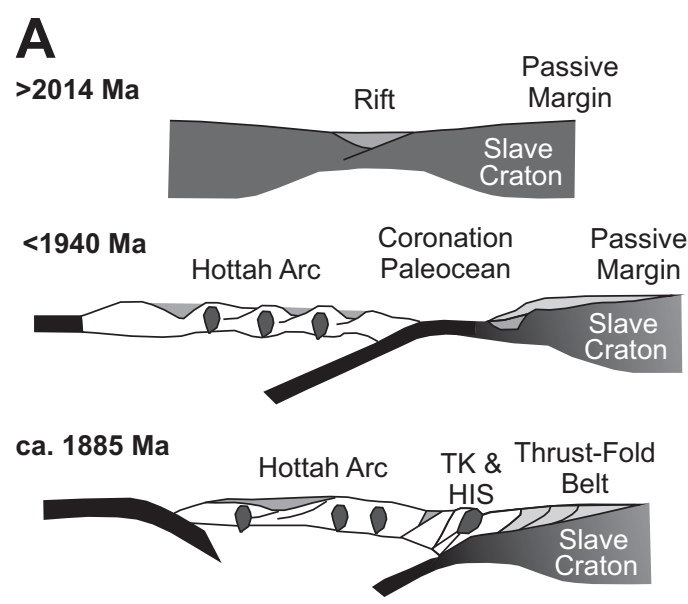

ca. $1875-1840 \mathrm{Ma}$

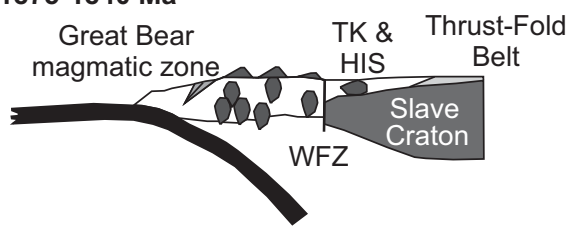

B

ca. 1940-1885 Ma Akaitcho seaway

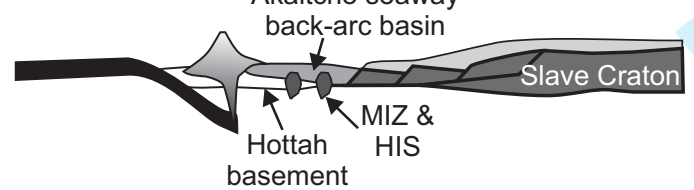

Figure 3: Ootes et al., Hottah Terrane 


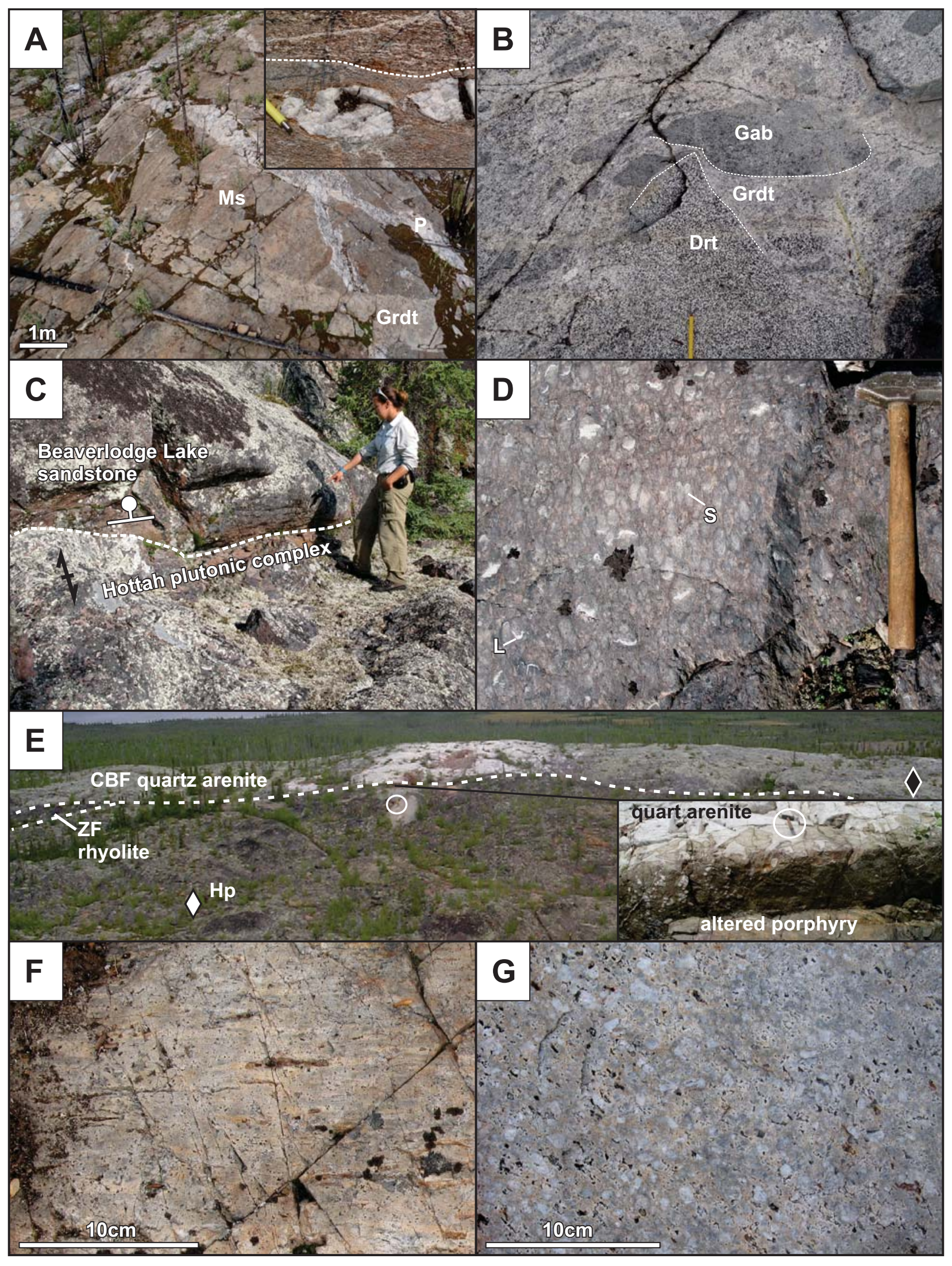

Figure 4: Ootes et al., Hottah Terrane 

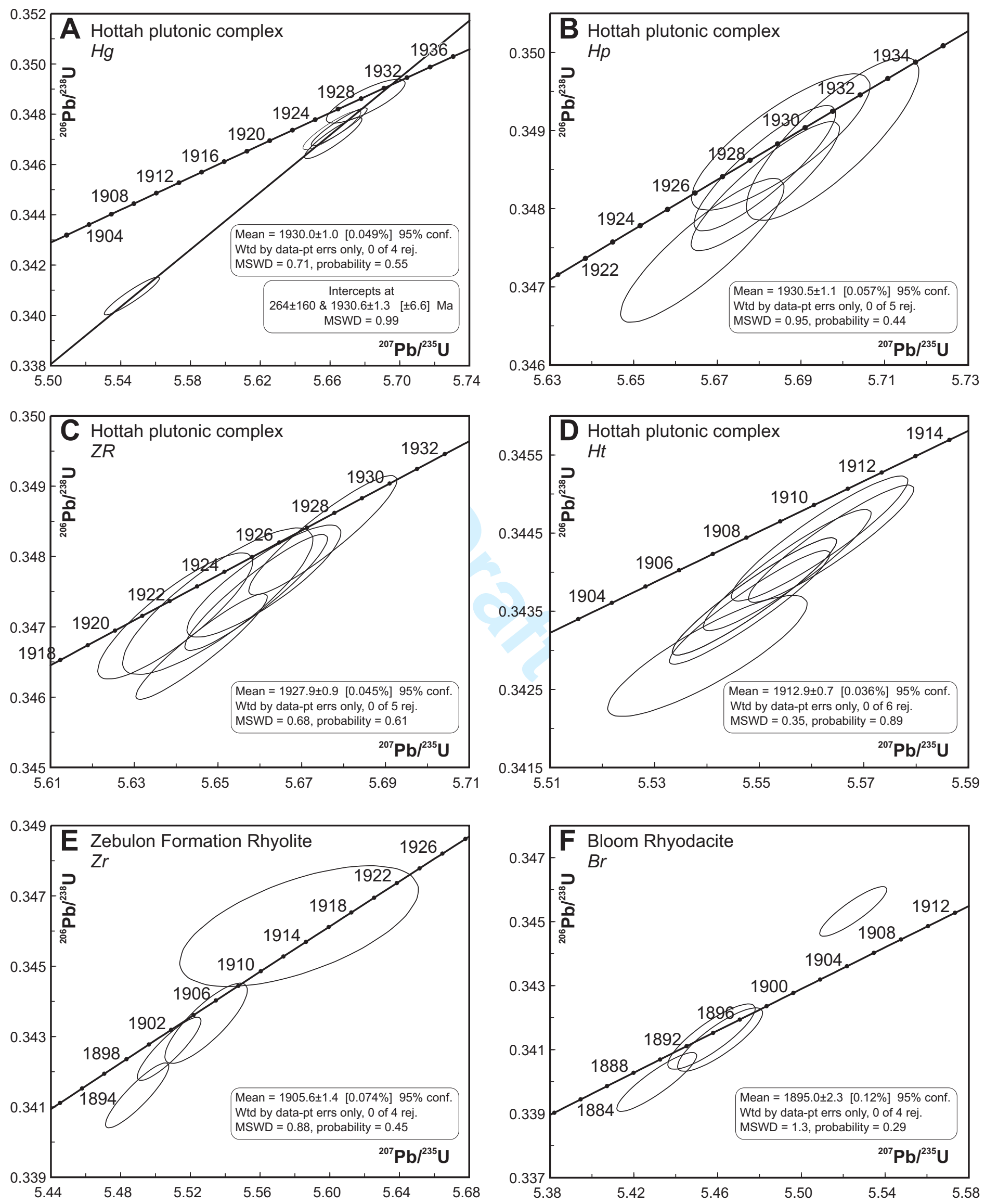

Figure 5. Ootes et al., Hołtathrineolbamenuscriptcentral.com/cjes-pubs 

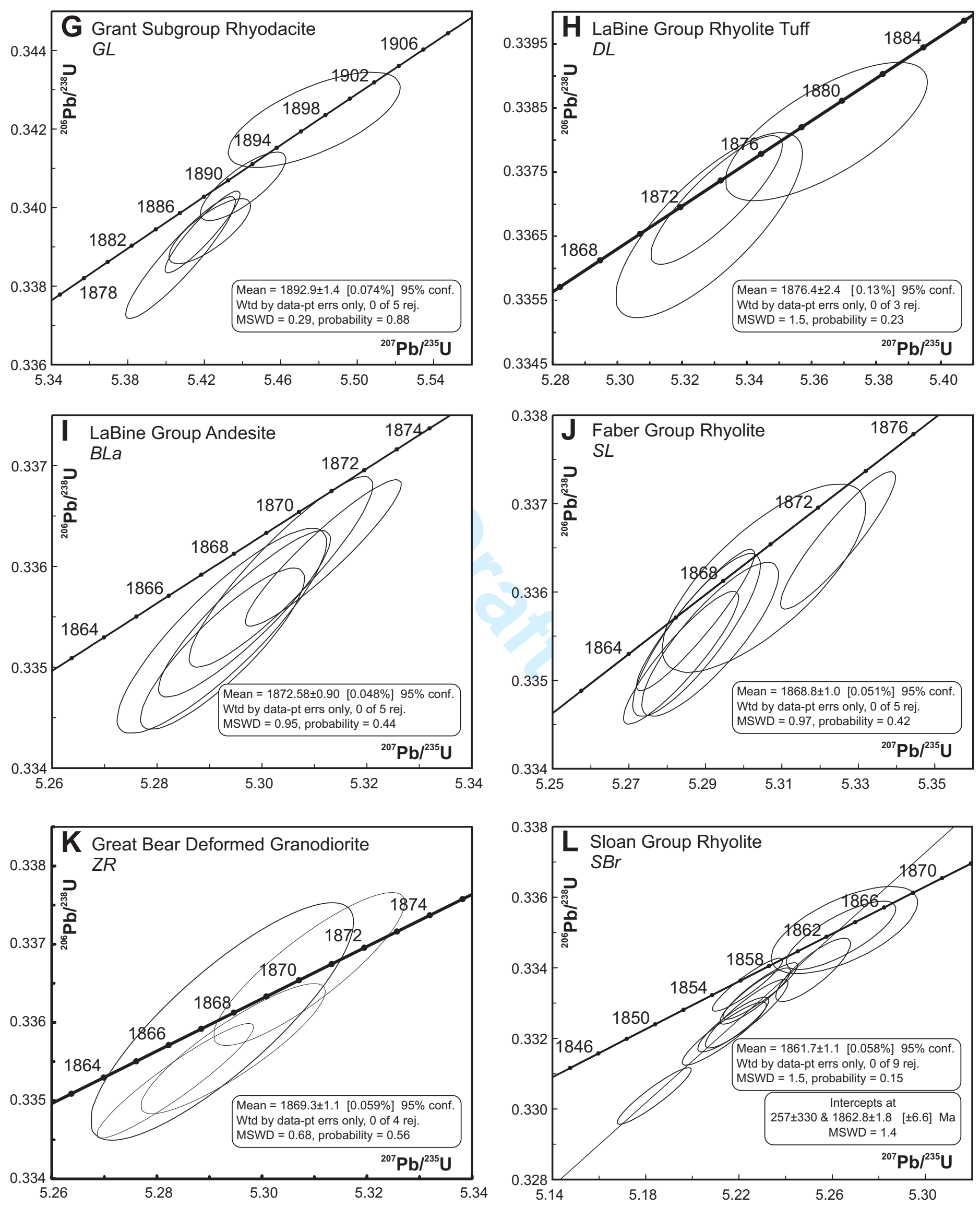

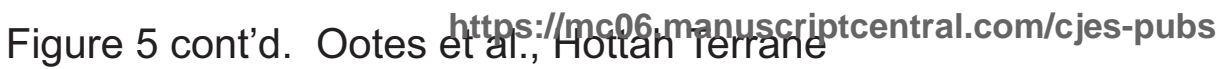



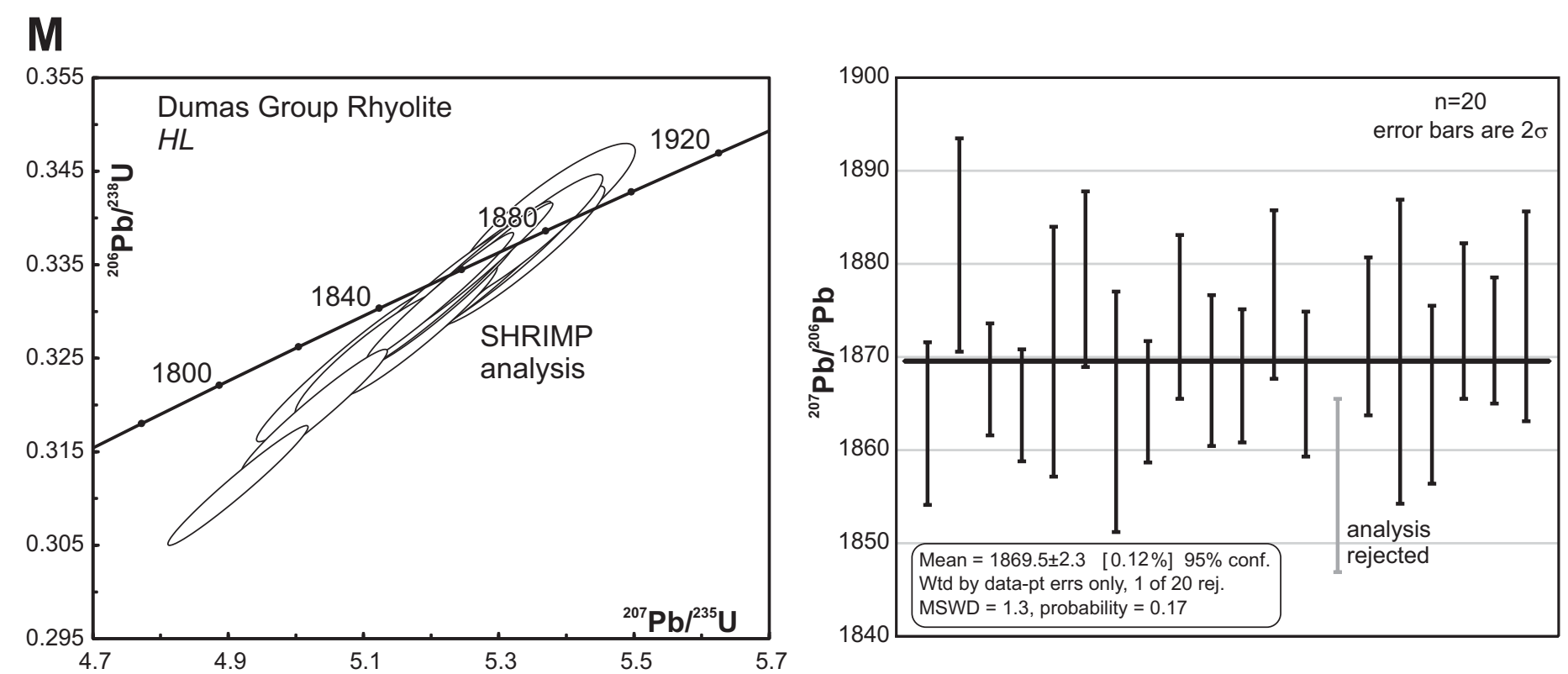

Figure 5 cont'd. Ootes et al., Hottah Terrane 


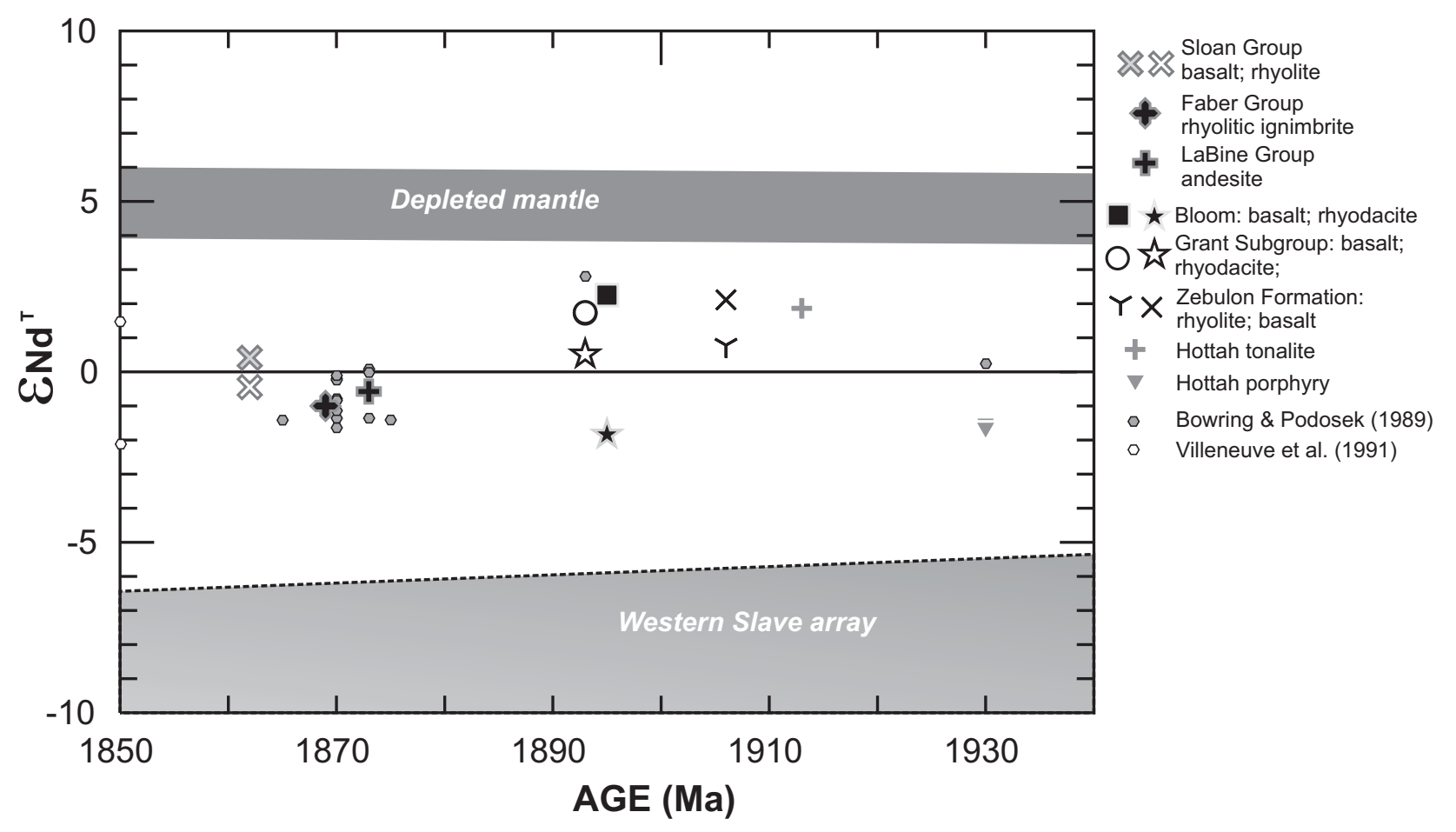

Figure 6. Ootes et al., Hottah Terrane 


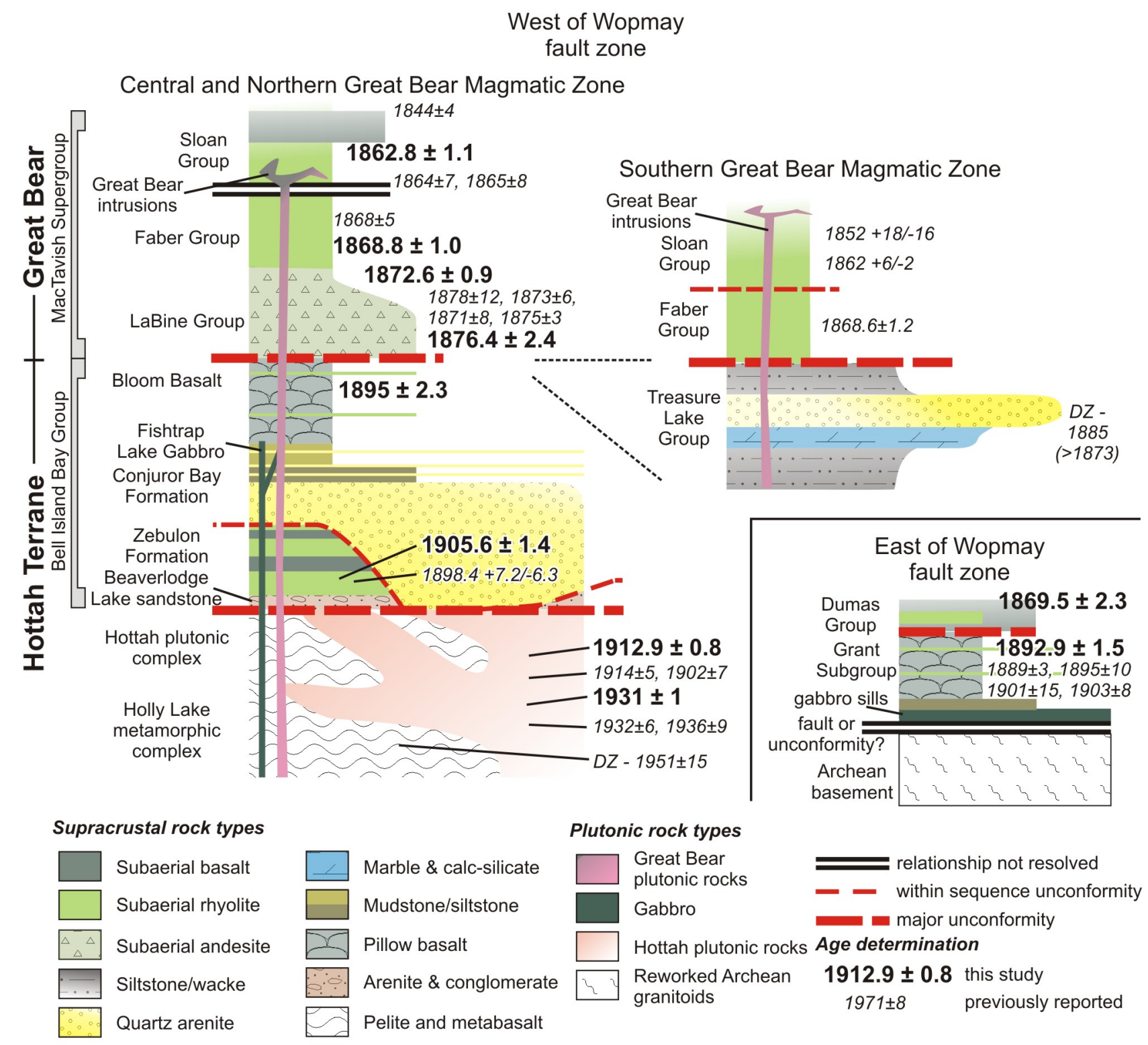

Figure 7. Ootes et al., Hottah Terrane 

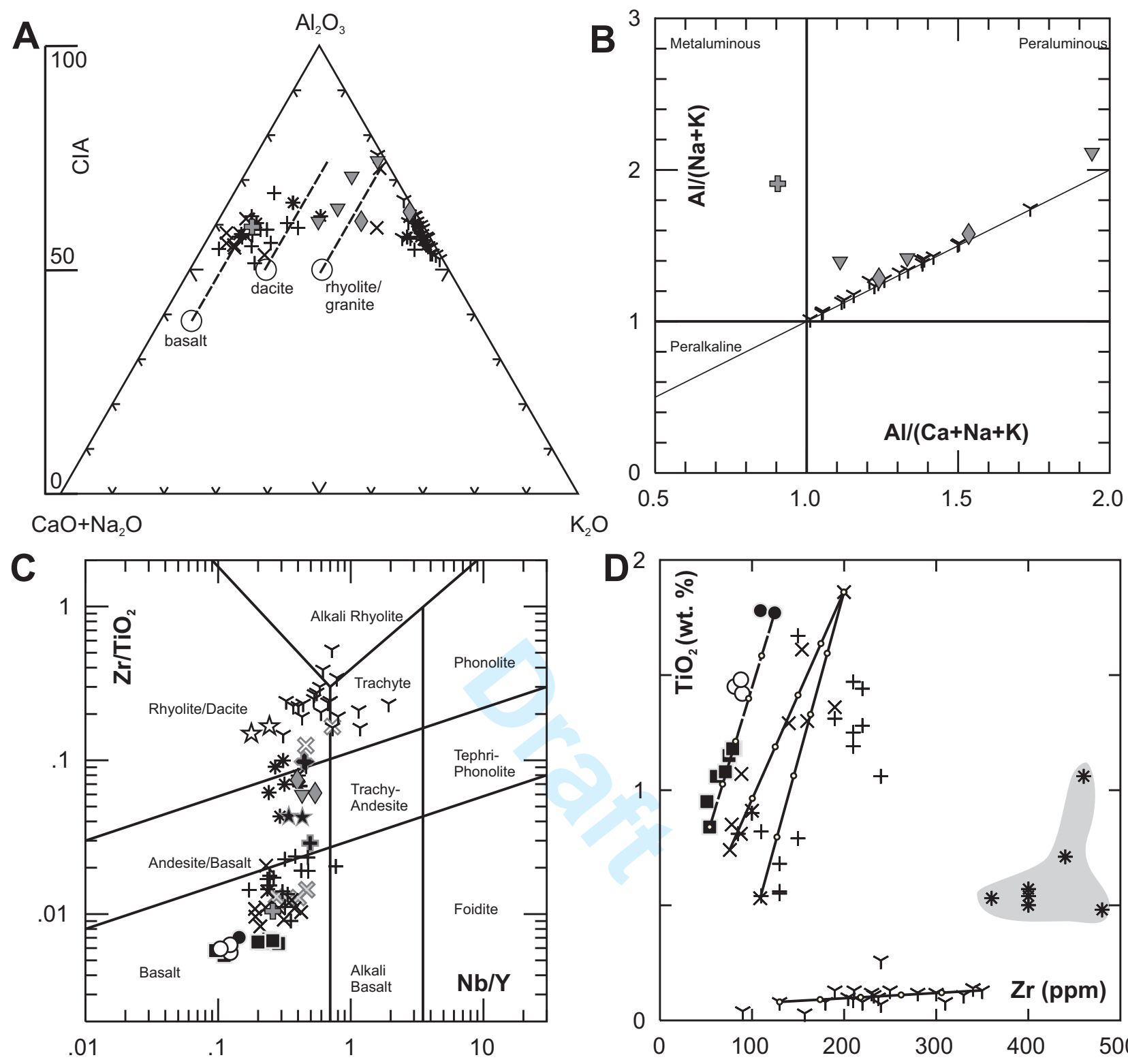

$\mathrm{K}_{2} \mathrm{O}$
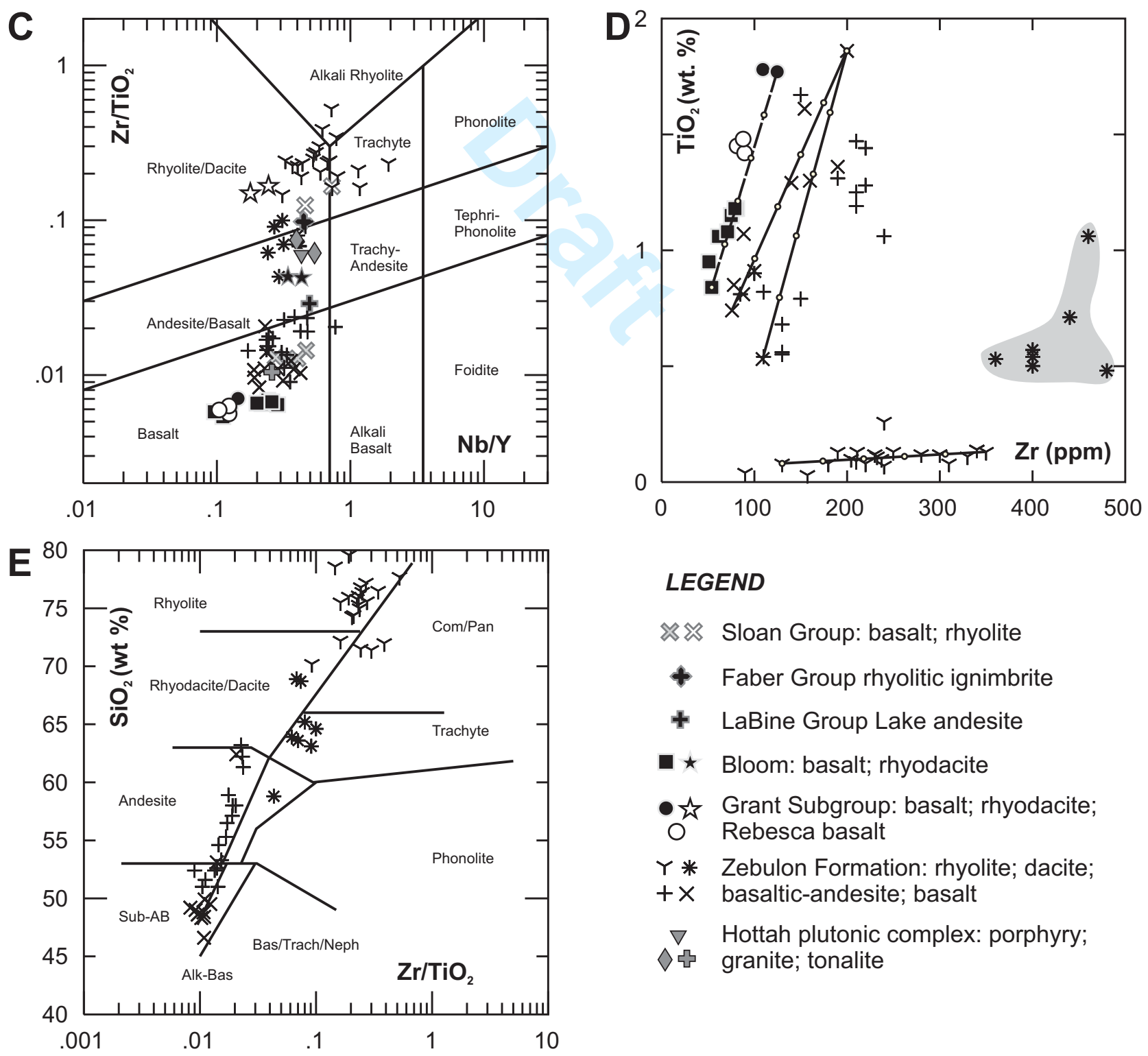

\section{LEGEND}

\S Sloan Group: basalt; rhyolite

+ Faber Group rhyolitic ignimbrite

+ LaBine Group Lake andesite

- $\star$ Bloom: basalt; rhyodacite

- « Grant Subgroup: basalt; rhyodacite;

O Rebesca basalt

$Y *$ Zebulon Formation: rhyolite; dacite;

$+\times$ basaltic-andesite; basalt

$\nabla \quad$ Hottah plutonic complex: porphyry;

$\diamond \rightsquigarrow$ granite; tonalite

Figure 8: Ootes ethalos:/HettahanTerrfanatral.com/cjes-pubs 
A

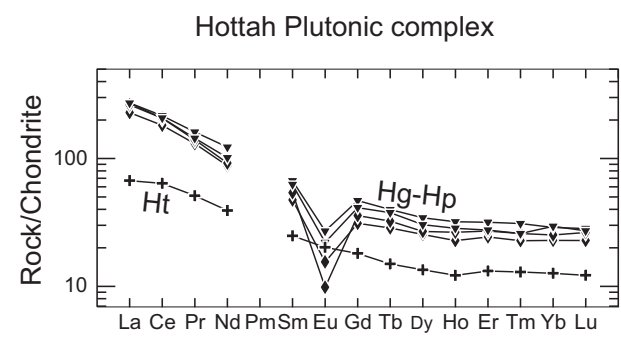

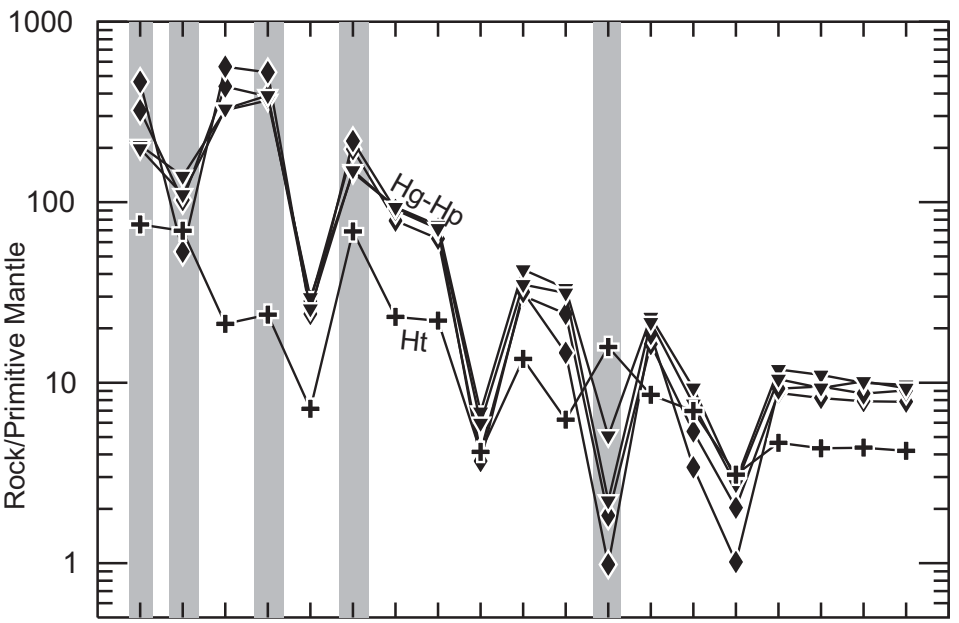

Rb Ba Th U Nb K La Ce P Nd Zr SrSmEu Ti Dy Y Yb Lu

B
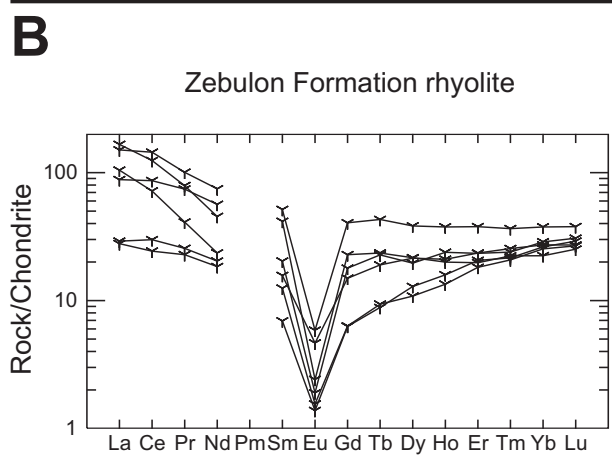

La Ce Pr NdPmSm Eu Gd Tb Dy Ho Er Tm Yb Lu

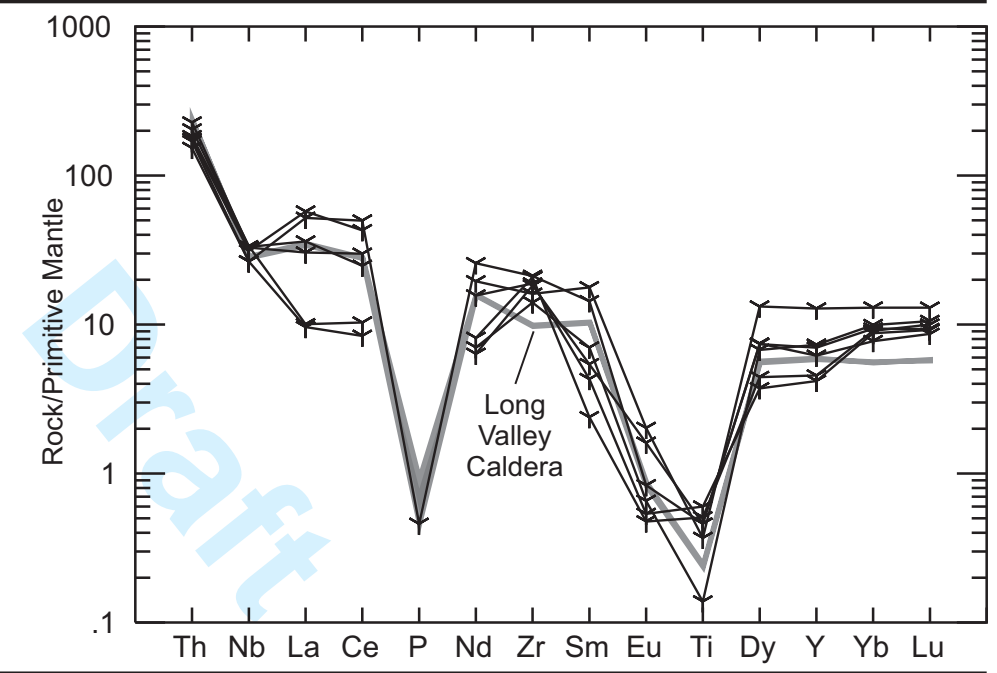

C
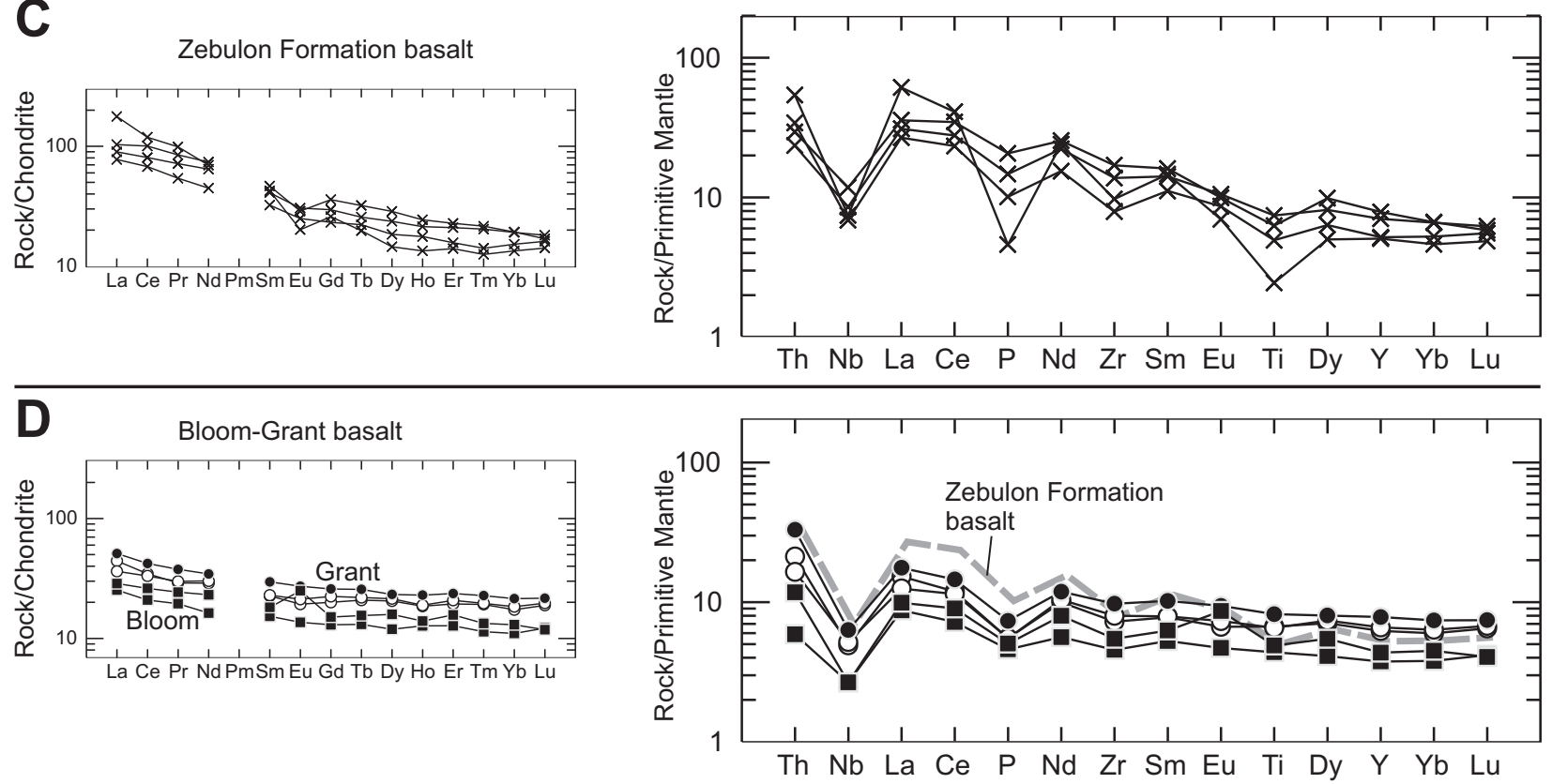

Figure 9: Ootes et al., Hottah Terrane 
E
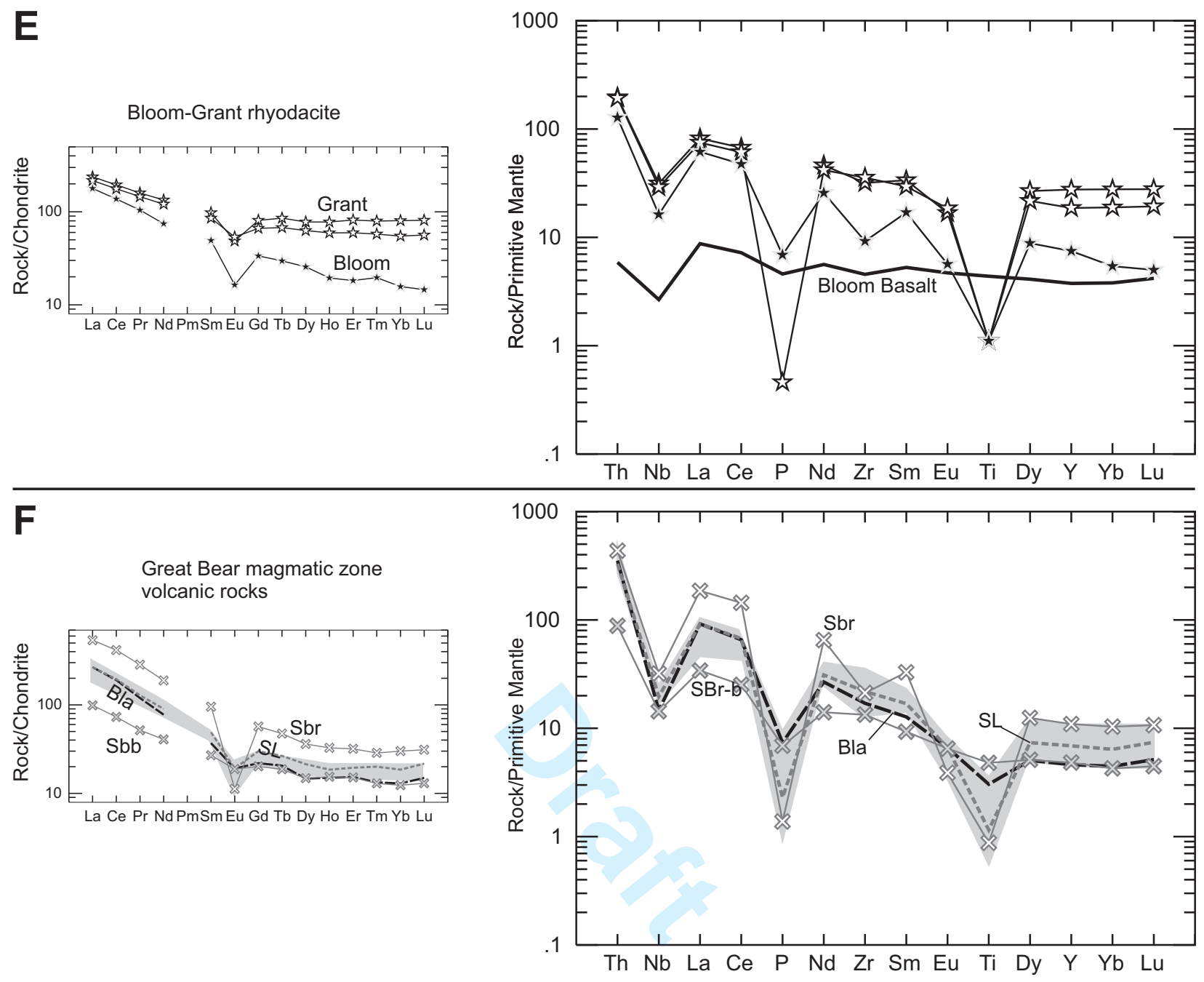

Figure 9 cont'd: Ootes et al., Hottah Terrane 
A

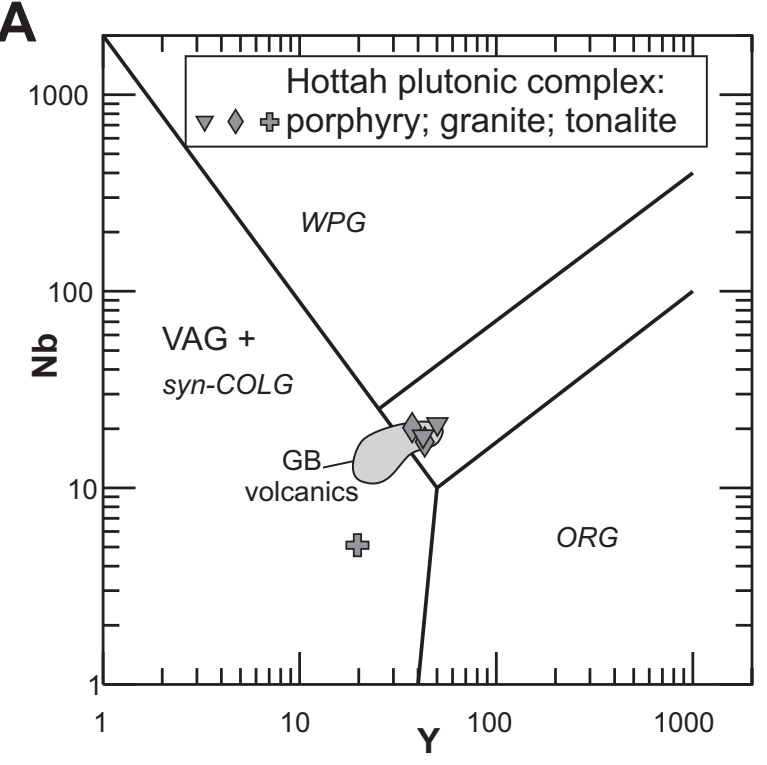

C

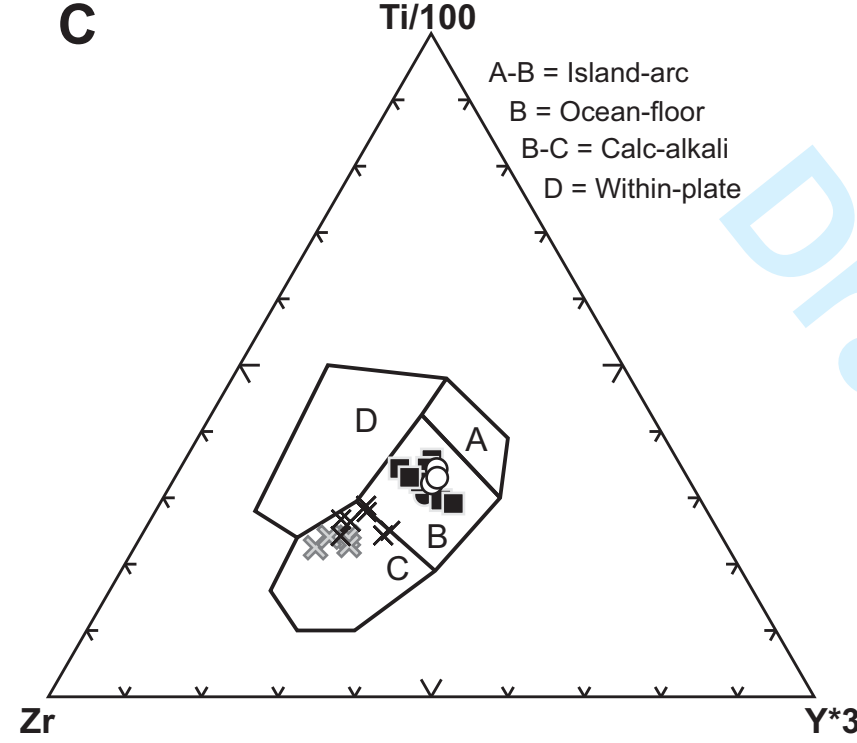

E

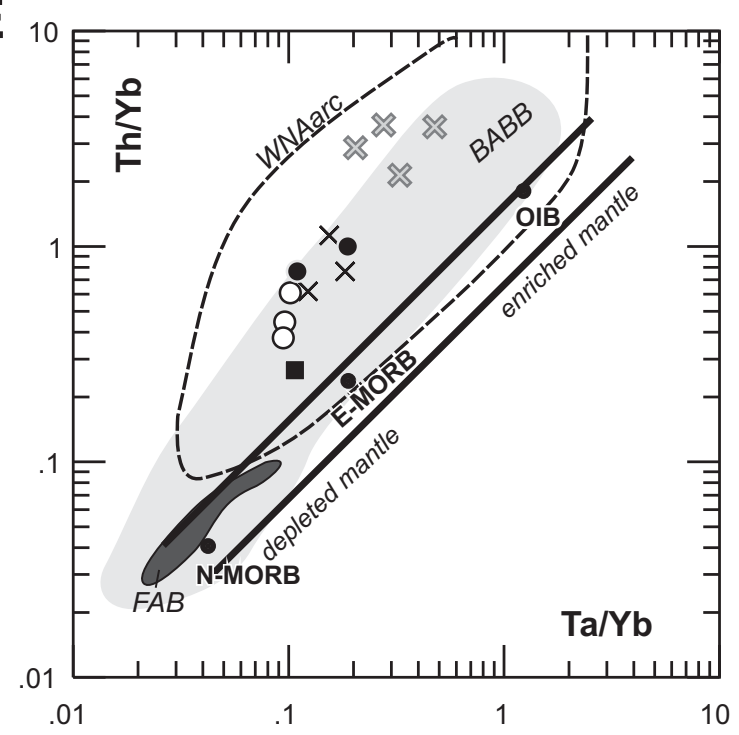

B

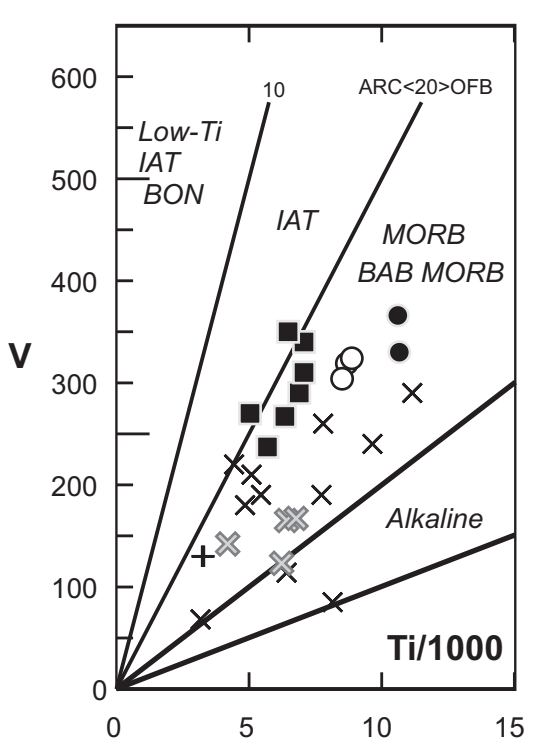

D

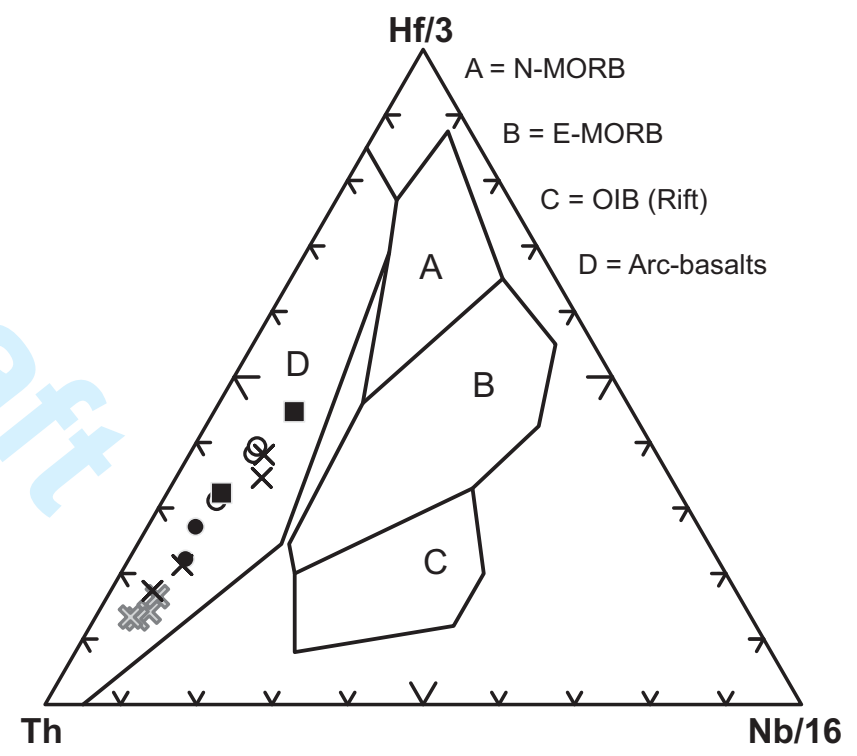

Figure 10: Ootes et al., Hottah terrane

https://mc06.manuscriptcentral.com/cjes-pubs 


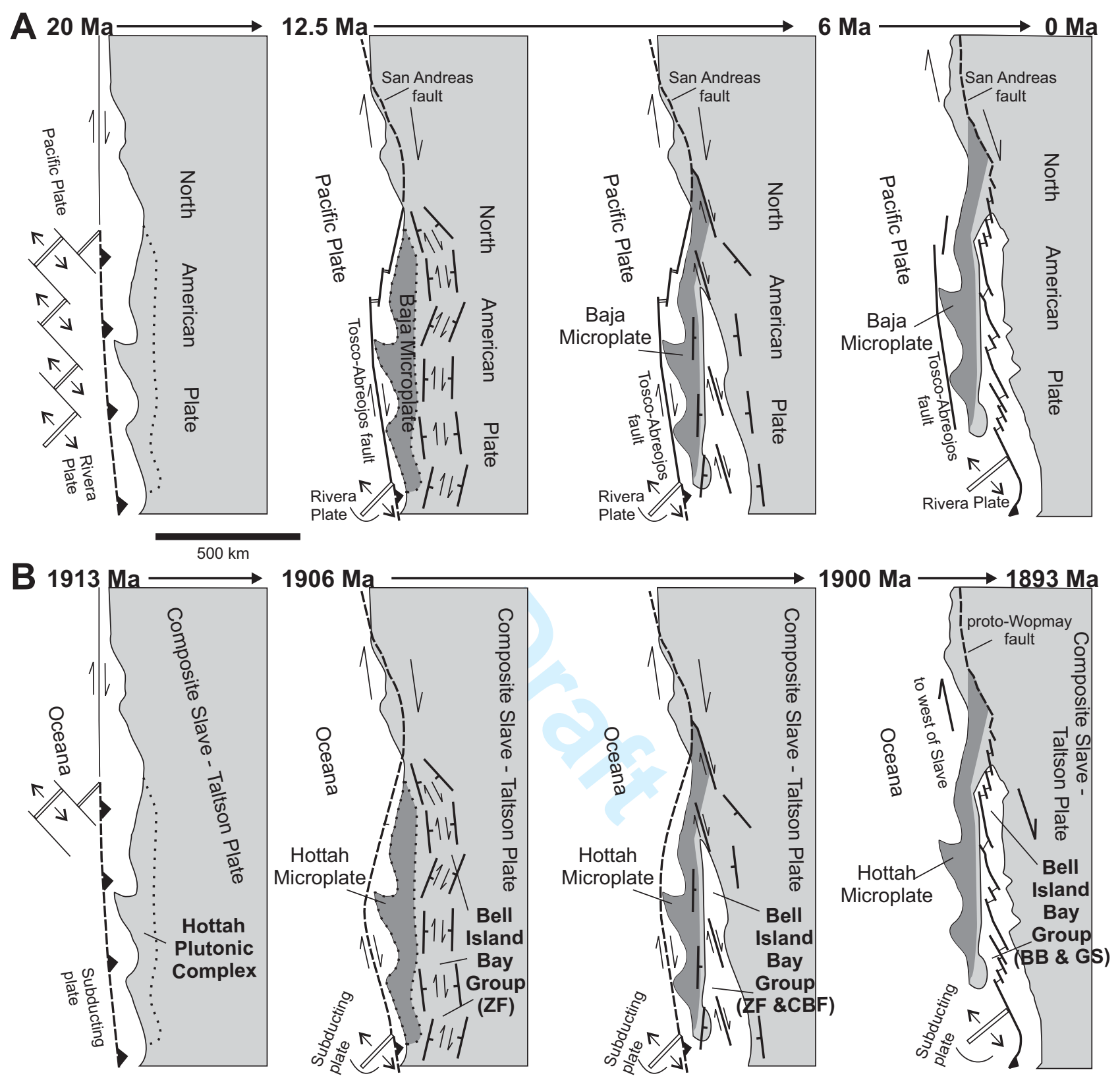

Figure 11: Ootes et al., Hottah terrane 
Table 1. TIMS U-Pb zircon results

Fraction Description ${ }^{1}$

Porphyritic granite $(\mathrm{Hg})-\mathrm{O}$

442095m E, 7177812m N 09109078A (Z10084)

A3-1 (Z) Z,Co,Clr,fln,Eu,Pr,Lch,NM1 ${ }^{\circ}$

A6-1 (Z) Z,Co,Cl, $\mathrm{C}, \mathrm{Eu}, \mathrm{Pr}, \mathrm{Lch}, \mathrm{NM1}$

B15-1 (Z) Z,Co,All, $Z$, In,Eu,Lch, ${ }^{\circ}$

B8-1 (Z) Z,Co,Alt,nFr,Eu,Pr,Lch M1

Hypabyssal porphyry (Hp) - 09109039A (Z1008)

*443456m E, 7179171m N

A10-1 (Z) Z,Co,Clr,Eu,Pr,Lch,NM10

A12-1 (Z) Z,Co,Clr,Eu,Pr,Lch,NM10

A14-1 (Z) Z,Co,Clr,Eu,Pr,Lch,NM5 ${ }^{\circ}$

A16-1 (Z) Z,Co,Clr,Eu,Pr,Lch,NM5 ${ }^{\circ}$

Clr, $\mathrm{Pu}$, Lch NM5

\section{Strongly deformed hornb}

A15-1 (Z) Z,Co,Clr,nln,Eu,Pr,Lch,M1 ${ }^{\circ}$

A16-1 (Z) Z,Co,Clr,Cln,Eu,Pr,Abr,NM1

A20-1 (Z) Z,Co,Clr,fln,Eu,Pr,Lch,NM1

B15-1 (Z) Z,Co,Clr,Cln,Eu,Pr,Lch,M1 $1^{\circ}$

B20-1 (Z) Z,Co,Clr,cln,Pr.Sub,Lch,NM1 ${ }^{\circ}$

\section{Foliated tonalite $(\mathrm{Ht})$ - 11lo4157a (Z10556)}

435738m E, 72

A10-1 (Z) Z,Co,Clr,nFr,Eu,Pr,Lch,M0

B10-1 (Z) Z,Co,Clr,fFr,Eu,Pr,Lch,M0

B10-2 (Z) Z,Co,Clr,fFr,Eu,Pr,LCh,M0

B5-1 (Z) Z, Co, Clr, nFr, $\mathrm{Fg}, \mathrm{Lch}, \mathrm{MO}^{\circ}$

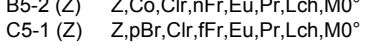

\section{Spherulitic rhyolite (Zr) - 10lo1116a (Z10321)}

AB16-1 (Z) Z,Co,Clr,Eu,Pr,Lch,NM3 ${ }^{\circ}$

B16-2 (Z) Z,Co,Clr,Eu,St,Lch,M3

B16-5 (Z) Z,Co,Clr,Eu,St,Lch,M3

\section{Rhyodacite (Br) - 11Lo4153a (Z10553)}

*435076m E, 7222942m N

A15-2 (Z) Z,Co,Clr,fFr,Eu,Mf,Tip,Lch,NM10

A16-2 (Z) Z, Co, Clr,Eu,Pr,Lch,NM10

A20-2 (Z) Z,Co,Clr,Eu,Pr,Lch,NM10

Rhyodacite (GL) - 09vj171A (Z9951) *520671m E, 7207791m N

A1A (Z) Z,Co,Clr,Eq,Eu,Abr,NM1

A3A (Z) Z, $\mathrm{Co}, \mathrm{Clr}, \mathrm{Eu}, \mathrm{Pr}, \mathrm{Abr}, \mathrm{NM} 1^{\circ}$

A4A (Z) Z,Co,Clr,Eq,Eu,Abr,NM1

B1 (Z) $\quad$ Z,Co,Clr,fFr,Eu,Pr,Abr,M3
B2 (Z) $\quad$ Z,Co,Clr,Eu,Pr,Abr,M3

Rhyolite ash tuff (DL) - 08vj19a (Z10813)
\# gr Size Wt. $\quad \mathrm{P} \quad \mathrm{Pbr}^{2} \quad{ }^{206} \mathrm{~Pb} / \mathrm{Pbc}^{2}{ }^{208} \mathrm{~Pb} / \quad{ }^{207} \mathrm{~Pb} /$

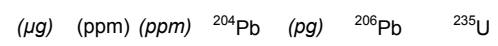

Radiogenic Ratios ( \pm 1sigma error absolute) $)^{3}$

${ }^{206} \mathrm{~Pb} / \quad$ Correlation $\quad{ }^{207} \mathrm{~Pb} /$

Age (Ma, $\pm 2 \sigma$ error) absolute

${ }^{207} \mathrm{~Pb} / \quad$ Discord

${ }^{206} \mathrm{~Pb} \quad \pm$

$\begin{array}{rrrrrrr}100 & 2.3 & 229 & 86 & 6135 & 1.8 & 0.16\end{array}$

\begin{tabular}{llllllllll}
170 & 2.4 & 182 & 70 & 1128 & 8.5 & 0.16 & 5.661 \\
\hline
\end{tabular}

$\begin{array}{llll}5.546 & 0.006 & 0.3407 & 0.0003\end{array}$

$\begin{array}{lll}0.007 & 0.3475 & 0.0003 \\ 0.009 & 0.3445 & 0.0003\end{array}$

$\begin{array}{lll}0.009 & 0.3485 & 0.0004 \\ 0.007 & 0.3471 & 0.0003\end{array}$

$\begin{array}{lll}0.9326 & 0.11824 & 0.00005 \\ 0.9060 & 0.11820 & 0.0000\end{array}$

$\begin{array}{llll}0.8185 & 0.11821 & 0.00012 \\ 0.000 & 0.1182 & 0.00006\end{array}$

$\begin{array}{lll}0.9068 & 0.11832 & 0.00006\end{array}$

1927.1

1929.8

1929.4

$\begin{array}{ll}1.6 & 2.22 \\ 1.6 & 0.43 \\ 1.9 & 0.43\end{array}$

$\begin{array}{ll}1.9 & 0.43 \\ 3.5 & 0.11 \\ 1.8 & 0.63\end{array}$

$\begin{array}{llllllllllll}2 & 100 & 1.4 & 154 & 58 & 2446 & 1.9 & 0.14 & 5.681 & 0.007 & 0.3483 & 0.0003\end{array}$

$\begin{array}{lllllll}100 & 2.1 & 81 & 30 & 895 & 4.2 & 0.14\end{array}$

$\begin{array}{lllllll}170 & 1.0 & 115 & 44 & 1604 & 1.6 & 0.15 \\ 120 & 1.0 & 121 & 45 & 1604 & 1.6 & 0.13\end{array}$

$\begin{array}{lllllll}120 & 1.0 & 121 & 45 & 1604 & 1.6 & 0.13 \\ 110 & 2.1 & 147 & 57 & 1280 & 5.3 & 0.18\end{array}$

$\begin{array}{llll}5.681 & 0.007 & 0.3483 & 0.0003 \\ 5.718 & 0.015 & 0.3489 & 0.0009 \\ 5.68 & 0.008 & 0.3489 & 0.004\end{array}$

$\begin{array}{llll}5.698 & 0.008 & 0.3489 & 0.0004 \\ 5.666 & 0.008 & 0.3475 & 0.0004\end{array}$

$\begin{array}{llll}5.666 & 0.008 & 0.3475 & 0.0004 \\ 5.685 & 0.009 & 0.3489 & 0.0004\end{array}$

$\begin{array}{lll}0.8901 & 0.11831 & 0.00007\end{array}$ \begin{tabular}{lll}
0.6439 & 0.11889 & 0.00026 \\
\hline
\end{tabular} $\begin{array}{lll}0.8239 & 0.11844 & 0.00010 \\ 0.8741 & 0.11828 & 0.00008 \\ 0.874 & 0.11819 & 0.00011\end{array}$ $\begin{array}{lll}0.8741 & 0.11828 & 0.00008 \\ 0.8174 & 0.11819 & 0.00011 \\ 0.873 & 0.11823 & 0.0007\end{array}$ $\begin{array}{lll}0.8174 & 0.11819 & 0.00011 \\ 0.8753 & 0.11823 & 0.00007\end{array}$

$\begin{array}{lll}1930.9 & 2.2 & 0.27\end{array}$

1932.8

1930.4

1929.1

$\begin{array}{lll}0.009 & 0.3489 & 0.0004 \\ 0.007 & 0.3485 & 0.0003\end{array}$

$\begin{array}{lll}0.8753 & 0.11823 & 0.00007\end{array}$ $\begin{array}{lll}0.8379 & 0.11797 & 0.00011 \\ 0.8631 & 0.11810 & 0.00008\end{array}$ $\begin{array}{lll}0.8602 & 0.11783 & 0.00008 \\ 0.9262 & 0.11812 & 0.00006\end{array}$ $\begin{array}{lll}0.9262 & 0.11812 & 0.00006 \\ 0.9366 & 0.11811 & 0.00005\end{array}$ $\begin{array}{lll}0.93215 & 0.11817 & 0.00006\end{array}$

$\begin{array}{lll}1925.7 & 3.3 & 0.23 \\ 1927.7 & 2.5 & 0.26 \\ 1923.5 & 2.5 & 0.16 \\ 1928.0 & 1.7 & 0.33 \\ 1927.9 & 1.6 & 0.54 \\ 1928.8 & 1.9 & 0.14\end{array}$

$\begin{array}{rrrrrrrr}1 & 200 & 6.4 & 98 & 36 & 6342 & 2.1 & 0.12 \\ 1 & 200 & 10.3 & 103 & 38 & 3304 & 6.9 & 0.11 \\ 1 & 225 & 20.6 & 108 & 39 & 7660 & 6.2 & 0.11 \\ 1 & 150 & 7.3 & 94 & 34 & 5578 & 2.7 & 0.12 \\ 1 & 200 & 21.6 & 109 & 40 & 11447 & 4.4 & 0.13 \\ 1 & 150 & 5.4 & 89 & 32 & 1456 & 7.1 & 0.12\end{array}$

$\begin{array}{lllll}5.564 & 0.006 & 0.3444 & 0.0003\end{array}$

$\begin{array}{llll}5.561 & 0.007 & 0.3444 & 0.0003\end{array}$

\begin{tabular}{llll}
5.549 & 0.006 & 0.3437 & 0.0003 \\
\hline
\end{tabular}

$\begin{array}{llll}5.555 & 0.007 & 0.3440 & 0.0003 \\ 5.548 & 0.006 & 0.3435 & 0.003\end{array}$ $\begin{array}{llll}5.548 & 0.006 & 0.3435 & 0.0003 \\ 5.540 & 0.008 & 0.3429 & 0.0003\end{array}$

$\begin{array}{lll}0.9316 & 0.11718 & 0.00005\end{array}$ $\begin{array}{lll}0.9228 & 0.11711 & 0.00006 \\ 0.9399 & 0.11710 & 0.00005\end{array}$ $\begin{array}{lll}0.9399 & 0.11710 & 0.00005 \\ 0.9300 & 0.11712 & 0.00006\end{array}$ $\begin{array}{lll}0.93405 & 0.11713 & 0.00005 \\ 0.9405 & 0.1177 & 0.0000\end{array}$ $\begin{array}{lll}0.9300 & 0.11712 & 0.00006 \\ 0.8560 & 0.11713 & 0.00005 \\ 0.117 & 0.00009\end{array}$ $\begin{array}{lll}1913.7 & 1.6 & 0.37\end{array}$ $\begin{array}{rrr}1912.6 & 1.9 & 0.28 \\ 1912.4 & 1.6 & 0.49\end{array}$ $\begin{array}{lll}1912.7 & 1.7 & 0.41\end{array}$ $\begin{array}{lll}1912.9 & 1.5 & 0.56 \\ 1913.5 & 2.8 & 0.78\end{array}$ $\begin{array}{rrrrrrrr}1 & 90 & 1.2 & 109 & 40 & 2279 & 1.2 & 0.14 \\ 1 & 100 & 1.0 & 119 & 45 & 233 & 11.9 & 0.16\end{array}$

$\begin{array}{llll}5.508 & 0.007 & 0.3426 & 0.0004\end{array}$ $\begin{array}{llll}5.582 & 0.028 & 0.3461 & 0.0007\end{array}$

$\begin{array}{lll}0.8830 & 0.11658 & 0.00008\end{array}$

$\begin{array}{lll}0.8912 & 0.11665 & 0.00007 \\ 0.8250 & 0.11679 & 0.00012\end{array}$

$\begin{array}{rrr}1904.5 & 2.3 & 0.32 \\ 190.4 & 14.8 & -0.35\end{array}$ $\begin{array}{lllllllllll}80 & 0.9 & 98 & 36 & 3189 & 0.4 & 0.14 & 5.489 & 0.007 & 0.3413 & 0.0004 \\ 82 & 0.8 & 93 & 34 & 1185 & 1.4 & 0.12 & 5.529 & 0.010 & 0.3434 & 0.0005\end{array}$

$\begin{array}{rrr}1910.4 & 14.8 & -0.35 \\ 1905.6 & 2.2 & 0.77\end{array}$

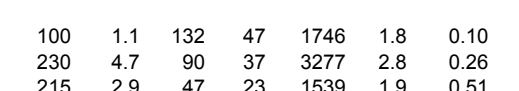

$\begin{array}{llll}5.431 & 0.008 & 0.3399 & 0.0004 \\ 5.525 & 0.007 & 0.3453 & 0.0003\end{array}$

$\begin{array}{llll}0.8911 & 0.11586 & 0.00008\end{array}$ $\begin{array}{lll}0.8783 & 0.11603 & 0.00007 \\ 0.819 & 0.11605 & 0.0010\end{array}$ $\begin{array}{lll}0.8500 & 0.11594 & 0.00010\end{array}$

1893.3

1896.0
1896.3
1894.5

$\begin{array}{ll}2.4 & 0.42 \\ 2.1 & -0.99\end{array}$ $\begin{array}{rrrrrrr}215 & 2.9 & 47 & 23 & 1539 & 1.9 & 0.51 \\ 175 & 2.0 & 123 & 53 & 1484 & 3.6 & 0.34\end{array}$ $\begin{array}{llll}5.461 & 0.008 & 0.3413 & 0.0004 \\ 5.457 & 0.009 & 0.3414 & 0.0004\end{array}$

$\begin{array}{rrrrrrr}110 & 1.3 & 177 & 67 & 2884.5 & 1.7 & 0.17 \\ 105 & 0.9 & 153 & 57 & 1270.6 & 2.3 & 0.17\end{array}$ $\begin{array}{rrrrrrr}105 & 0.9 & 153 & 57 & 1270.6 & 2.3 & 0.17 \\ 80 & 0.6 & 128 & 48 & 346.2 & 4.9 & 0.16\end{array}$ $\begin{array}{rrrrrrr}90 & 0.0 & 128 & 48 & 346.2 & 4.9 & 0.16 \\ 100 & 1.9 & 125 & 33 & 953.2 & 4.0 & 0.17 \\ & & & & & & \end{array}$ $\begin{array}{llll}5.419 & 0.008 & 0.3394 & 0.0004 \\ 5.407 & 0.012 & 0.3387 & 0.0006 \\ 5.477 & 0.018 & 0.3422 & 0.0005 \\ 5.440 & 0.009 & 0.3405 & 0.0004 \\ 5.423 & 0.009 & 0.3394 & 0.0003\end{array}$

$\begin{array}{lll}0.9212 & 0.11581 & 0.00007 \\ 0.9237 & 0.11579 & 0.00010\end{array}$ $\begin{array}{lll}0.9237 & 0.11579 & 0.00010 \\ 0.6747 & 0.11608 & 0.00030\end{array}$ $\begin{array}{lll}0.6747 & 0.11608 & 0.00030 \\ 0.7930 & 0.11587 & 0.00012\end{array}$ 1892.6
1892.3 1892.3
1896.7 
*512484m E, 7130288m N

A20-1 (Z) Z,Co,Clr,fFr,EI,Mf,Pr,Lch,M1

A20-2 (Z) Z,Co,Clr,El,Mi,Pr,Lch,M

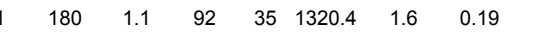

A20-3 (Z) Z,Co,Clr,Mf,Pr,Lch,M1

$\begin{array}{lllllll}180 & 1.1 & 92 & 35 & 1320.4 & 1.6 & 0.19 \\ 110 & 0.6 & 76 & 34 & 735.9 & 1.3 & 0.4\end{array}$

$\begin{array}{llllllll}120 & 1.1 & 83 & 34 & 735.9 & 1.3 & 0.41\end{array}$

$\begin{array}{llll}5.331 & 0.008 & 0.3371 & 0.0004 \\ 5.328 & 0.012 & 0.3367 & 0.0006\end{array}$

Fragmental andesite (BLa) - 10vj186a (Z10322)

$447400 \mathrm{~m} \mathrm{E}, 7177920 \mathrm{~m} \mathrm{~N}$

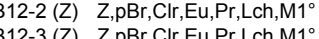

C16-1 (Z) Z,Co,Clr,Eu,Pr,Lch,M3 ${ }^{\circ}$

C16-2 (Z) Z,Co,Clr,Eu,Pr,Lch,M3

C16-3 (Z) Z,Co,Clr,Eu,Pr,Lch,M3

$\begin{array}{rrrrrrr}186 & 5.3 & 178 & 65 & 6953 & 2.9 & 0.14 \\ 128 & 2.3 & 85 & 30 & 3343 & 1.2 & 0.11\end{array}$

$\begin{array}{rrrrrrr}140 & 1.0 & 125 & 30 & 3343 & 1.2 & 0.11 \\ 138 & 2.4 & 116 & 41 & 2154 & 1.1 & 0.14 \\ 12077 & 0.8 & 0.12\end{array}$

$\begin{array}{lllllll}138 & 2.4 & 116 & 41 & 5077 & 0.8 & 0.12 \\ 120 & 1.9 & 203 & 73 & 4284 & 1.9 & 0.14\end{array}$

Rhyolite ignimbrite (SL) - 10lo1131b (Z10324)

$462754 \mathrm{~m} \mathrm{E}, 7201067 \mathrm{~m} \mathrm{~N}$

A20-2 (Z) Z, Co,Clr,Eu,Pr,Lch,M1 ${ }^{\circ}$

A25-1 (Z) Z,Co,Clr,Eq,Eu,Pr,Lch,M

A25-4 (Z) Z,Co,ClrEu, Pr,Lch M1

A30-1 (Z) Z,Co,ClrEu St,Lch,M1

A30-2 (Z) Z,Co,Clr,Eu,Lch,M1 ${ }^{\circ}$

$\begin{array}{rrrrrrrr}1 & 111 & 1.4 & 148 & 52 & 1905 & 1.5 & 0.11 \\ 1 & 118 & 2.5 & 154 & 56 & 14427 & 0.6 & 0.13 \\ 1 & 167 & 3.1 & 156 & 57 & 17252 & 0.4 & 0.15 \\ 1 & 119 & 1.5 & 100 & 36 & 5041 & 0.6 & 0.13 \\ 1 & 113 & 2.0 & 174 & 63 & 5738 & 1.3 & 0.13 \\ 1 & 86 & 1.1 & 81 & 29 & 705 & 2.7 & 0.11\end{array}$

$\begin{array}{llll}5.312 & 0.006 & 0.3361 & 0.0003\end{array}$

$\begin{array}{llll}5.297 & 0.007 & 0.3355 & 0.0003 \\ 5.292 & 0.008 & 0.3354 & 0.0004\end{array}$

$\begin{array}{lllll}5.304 & 0.007 & 0.3359 & 0.0004 \\ 5 & 0.006 & 0.3352 & 0.0003\end{array}$

$\begin{array}{lll}0.006 & 0.3352 & 0.0003\end{array}$

$\begin{array}{lll}0.9353 & 0.11461 & 0.00005 \\ 0.8585 & 0.11419 & 0.00007\end{array}$

$\begin{array}{llll}0.8643 & 0.11446 & 0.00007 \\ 0.0000\end{array}$

$\begin{array}{lll}0.9078 & 0.11450 & 0.00007\end{array}$

$\begin{array}{lll}0.8694 & 0.11452 & 0.00007\end{array}$

1871.9
1871.4
1872.0

872.0
872.4

$\begin{array}{ll}2.8 & 0.44 \\ 2.1 & 0.30\end{array}$

$\begin{array}{llll}5.291 & 0.007 & 0.3355 & 0.0004\end{array}$

$\begin{array}{llll}5.287 & 0.006 & 0.3357 & 0.0003 \\ 5.325 & 0.006 & 0.3366 & 0.0003\end{array}$

$\begin{array}{lll}0.8417 & 0.11440 & 0.00009\end{array}$

$\begin{array}{lll}0.9301 & 0.11424 & 0.00005 \\ 0.9169 & 0.11474 & 0.00006\end{array}$

$\begin{array}{lll}0.8550 & 0.11430 & 0.000008\end{array}$

$\begin{array}{llll}0.9071 & 0.11430 & 0.00006\end{array}$

$\begin{array}{lll}0.7445 & 0.11446 & 0.00016\end{array}$

1870.4

1867.9

1869.0

1868.9
1871.5

$\begin{array}{llll}5.283 & 0.006 & 0.3352 & 0.004 \\ 5.305 & 0.011 & 0.3362 & 0.0004\end{array}$

Deformed hornblende-biotite granodiorite (ZR) - 11104155a (Z10554)

$452952 \mathrm{~m} \mathrm{E}, 7208216 \mathrm{~m} \mathrm{~N}$

A16-1 (Z) Z, Co,Clr,Eq,Pr, Lch,NM5 ${ }^{\circ}$

A16-2 (Z) Z,Co,Clr,nFr,Mf,Pr,Lch,NM5

A16-4 (Z) Z Z Co, Clr.nFr, StLCh, NM5

$\begin{array}{rrrrrrr}100 & 3.4 & 210 & 77 & 10620 & 1.4 & 0.16 \\ 100 & 1.6 & 154 & 56 & 2585.2 & 2.0 & 0.14 \\ 90 & 1.1 & 154 & 56 & 2499.7 & 1.4 & 0.15 \\ 110 & 1.6 & 165 & 62 & 1930.6 & 2.9 & 0.18\end{array}$

$\begin{array}{llll}5.283 & 0.006 & 0.3353 & 0.0003 \\ 5.292 & 0.010 & 0.3360 & 0.0006\end{array}$

$\begin{array}{lll}0.9371 & 0.11430 & 0.00005\end{array}$

$\begin{array}{llll}0.8382 & 0.11423 & 0.00012 & 1867.8 \\ 0.8666 & 0.11437 & 0.0000 & 1869\end{array}$

$\begin{array}{llll}0.8793 & 0.11440 & 0.00008 & 1870.4\end{array}$

$\begin{array}{ll}1.6 & 0.31 \\ 3.9 & 0.02\end{array}$

$\begin{array}{ll}0.3367 & 0.0004 \\ 0.357 & 0.0003\end{array}$

Rhyolite crystal tuff (SBr) - 10101144c (Z10323)

A20-1 (Z) Z, $\mathrm{Co}, \mathrm{Clr}, \mathrm{Eu}, \mathrm{St}, \mathrm{Lch}, \mathrm{NM}^{\circ}$

A20-2 (Z) Z,Co,Clr,Eu,Pr,LCh,NM3 ${ }^{\circ}$

$\mathrm{A} 30-1$ (Z) Z,Co,Clr,Eq,Eu,St,Lch,NM3

A30-2 (Z) Z,Co,Clr,Eu,Pr, Lch,M3 ${ }^{\circ}$

(Z) $\mathrm{Z}, \mathrm{Co}, \mathrm{Cl}, \mathrm{Eu}, \mathrm{ST}, \mathrm{LCh}, \mathrm{NM}^{\circ}$

B30-1 (Z) Z Z Co,Clr Fg PrLchM3

B30-2 (Z) Z $\mathrm{ZCO}, \mathrm{Cl} \mathrm{Eu}$ Pr $\mathrm{Lch} \mathrm{M}^{\circ}$

B30-3 (Z) Z,Co,Clr,Eu,Pr,Lch,M3

B30-4 (Z) Z,Co,Clr,Eu,Pr,Lch,M3

$\begin{array}{rrrrrrr}162 & 3.6 & 250 & 94 & 8198 & 2.3 & 0.19 \\ 106 & 1.4 & 285 & 106 & 5024 & 1.6 & 0.19 \\ 167 & 6.4 & 62 & 23 & 8429 & 0.9 & 0.20 \\ 154 & 5.5 & 61 & 23 & 7354 & 1.0 & 0.17 \\ 100 & 2.3 & 100 & 38 & 503 & 9.9 & 0.20 \\ 100 & 3.8 & 118 & 44 & 3787 & 2.5 & 0.19 \\ 100 & 1.5 & 114 & 42 & 907 & 4.0 & 0.17 \\ 145 & 1.5 & 111 & 42 & 5523 & 0.6 & 0.22 \\ 173 & 2.7 & 116 & 43 & 2502 & 2.6 & 0.18 \\ 124 & 1.2 & 126 & 47 & 4263 & 0.7 & 0.18\end{array}$

$\begin{array}{llll}5.252 & 0.007 & 0.3339 & 0.0004 \\ 5.183 & 0.007 & 0.3303 & 0.0003 \\ 5.227 & 0.006 & 0.3332 & 0.0003 \\ 5.224 & 0.006 & 0.3335 & 0.0003 \\ 5.265 & 0.013 & 0.3351 & 0.0005 \\ 5.229 & 0.007 & 0.3333 & 0.0003 \\ 5.264 & 0.010 & 0.3349 & 0.0004 \\ 5.217 & 0.006 & 0.3324 & 0.0003 \\ 5.214 & 0.007 & 0.3321 & 0.0004 \\ 5.223 & 0.007 & 0.3327 & 0.0004\end{array}$

$\begin{array}{lll}0.8296 & 0.11406 & 0.00008\end{array}$

$\begin{array}{lll}0.9293 & 0.11381 & 0.00006\end{array}$

$\begin{array}{llll}0.8970 & 0.11378 & 0.00006\end{array}$

$\begin{array}{lll}0.9164 & 0.11359 & 0.00006 \\ 0.0368 & 0.11396 & 0.00021\end{array}$

$\begin{array}{lll}0.6368 & 0.11396 & 0.00021 \\ 0.0093 & 0.11377 & 0.00006\end{array}$

$\begin{array}{llll}0.7759 & 0.11398 & 0.00013\end{array}$

$\begin{array}{llll}0.8781 & 0.11385 & 0.00007\end{array}$

$\begin{array}{llll}0.9102 & 0.11385 & 0.00007 \\ 0.8991 & 0.11387 & 0.00007\end{array}$

$\begin{array}{llll}0.8991 & 0.11387 & 0.00007\end{array}$

$\begin{array}{lll}1865.1 & 2.5 & 0.48\end{array}$

$\begin{array}{lll}1861.1 & 1.8 & 0.48 \\ 1860.0 & 1.9 & 0.31\end{array}$

1857.7

1863.6

1860.6

1861.8

1861.8
1862.1

$\begin{array}{ll}2.7 & 0.35 \\ 1.6 & 0.13 \\ 1.7 & 0.34 \\ 2.4 & 0.24 \\ 1.8 & 0.32 \\ 5.0 & 0.21\end{array}$

sample coordinates in UTM Zone 11, NAD 83 .

Description Legend: Z=Zircon, Co=Colourless, $\mathrm{pBr}=\mathrm{Pale}$ Brown, Alt=Altered, Clr=Clear, $\mathrm{fFr}=\mathrm{Few}$ Fractures, $\mathrm{nFr}=$ Numerous Fractures, cln=Clear Inclusions, fln=Few Inclusions, nln=Numerous Inclusions, Eq=Equant, Eu=Euhedral, Fg=Fragment, Pr=Prismatic, St=Stubby Prism, Sub=Subhedral, Tab=Tabular, Tip=Tip, Abr=Abraded, Lch=Leached

(1) Weights estimated Concentration uncertainty up to $50 \%$

(2) $\mathrm{Pbr}=$ radiogenic $\mathrm{Pb}$. $\mathrm{Pbc}=$ total common $\mathrm{Pb}$ in analysis corrected for spike and fractionation

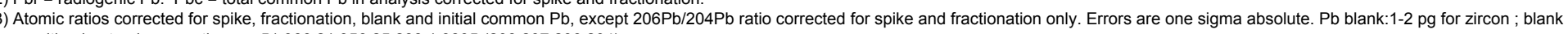


Table 2. SHRIMP II U-Pb zircon results

Rhyodacite (HL) - 09vj148c (Z9952)

\begin{tabular}{|c|c|c|c|c|c|c|c|c|c|c|c|c|c|c|c|c|c|c|c|}
\hline Spot & $\underset{(\mathrm{ppm})}{U}$ & $\begin{array}{c}\text { Th } \\
(\mathrm{ppm})\end{array}$ & $\frac{T h}{U}$ & $\begin{array}{c}206 \mathrm{~Pb}^{*} \\
(\mathrm{ppm})\end{array}$ & $\frac{{ }^{204} \mathrm{~Pb}}{{ }^{206} \mathrm{~Pb}}$ & $\pm \frac{{ }^{204} \mathrm{~Pb}}{{ }^{206} \mathrm{~Pb}}$ & $f(206)^{204}$ & $\frac{208^{*} \mathrm{~Pb}}{{ }^{206^{*}} \mathrm{~Pb}}$ & ${ }^{ \pm{ }^{206} \mathrm{~Pb}} \mathrm{~Pb}$ & $\frac{\frac{{ }^{207^{*}} \mathrm{~Pb}}{{ }^{235} \mathrm{U}}}{{ }^{2}}$ & $\frac{ \pm^{207} \mathrm{~Pb}}{{ }^{235} \mathrm{U}}$ & $\frac{{ }^{206 "} \mathrm{~Pb}}{{ }^{238} \mathrm{U}}$ & $\frac{ \pm^{206} \mathrm{~Pb}}{{ }^{238} \mathrm{U}}$ & $\begin{array}{l}\text { Corr } \\
\text { Coeff }\end{array}$ & $\frac{207^{7 *} \mathrm{~Pb}}{{ }^{206^{*}} \mathrm{~Pb}}$ & ${ }^{ \pm^{206} \mathrm{~Pb}}$ & $\frac{{ }^{207} \mathrm{~Pb}}{{ }^{206} \mathrm{~Pb}}$ & $\frac{ \pm^{207} \mathrm{~Pb}}{{ }^{206} \mathrm{~Pb}}$ & $\begin{array}{c}\text { Disc. } \\
(\%)\end{array}$ \\
\hline$\overline{9952-002.1}$ & 384 & 225 & 0.584 & 110 & $\begin{array}{l}2.132 \mathrm{E}-06 \\
\end{array}$ & $\overline{2.132 \mathrm{E}-06}$ & 0.044 & 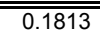 & 0.0021 & (5.212 & "0.047 & 0.3319 & 0.0029 & 0.9635 & 0.1139 & 0.00028 & 1863 & 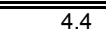 & $\overline{\overline{1.0}}$ \\
\hline $9952-030.1$ & 252 & 143 & 0.568 & 73 & $2.640 \mathrm{E}-05$ & $9.334 \mathrm{E}-06$ & 0.556 & 0.1751 & 0.0025 & 5.333 & 0.051 & 0.3359 & 0.0031 & 0.9440 & 0.1151 & 0.00037 & 1882 & 5.7 & 0.9 \\
\hline $9952-007.1$ & 840 & 746 & 0.888 & 242 & $-1.006 \mathrm{E}-06$ & $-1.006 \mathrm{E}-06$ & -0.014 & 0.2716 & 0.0031 & 5.272 & 0.045 & 0.3348 & 0.0028 & 0.9807 & 0.1142 & 0.00019 & 1868 & 3.0 & 0.4 \\
\hline $9952-001.1$ & 817 & 1024 & 1.252 & 233 & $3.937 \mathrm{E}-06$ & $1.968 \mathrm{E}-06$ & 0.037 & 0.3915 & 0.0021 & 5.215 & 0.045 & 0.3317 & 0.0028 & 0.9808 & 0.1140 & 0.00019 & 1865 & 3.0 & 1.1 \\
\hline $9952-004.1$ & 227 & 177 & 0.782 & 65 & $7.273 \mathrm{E}-05$ & $1.626 \mathrm{E}-05$ & 1.106 & 0.2414 & 0.0031 & 5.237 & 0.052 & 0.3320 & 0.0031 & 0.9271 & 0.1144 & 0.00043 & 1871 & 6.7 & 1.4 \\
\hline $9952-017.1$ & 315 & 109 & 0.345 & 91 & $1.415 \mathrm{E}-05$ & $5.776 \mathrm{E}-06$ & 0.480 & 0.1088 & 0.0017 & 5.311 & 0.049 & 0.3352 & 0.0030 & 0.9588 & 0.1149 & 0.00030 & 1878 & 4.7 & 0.9 \\
\hline $9952-015.1$ & 468 & 244 & 0.522 & 131 & $4.285 \mathrm{E}-05$ & $8.569 \mathrm{E}-06$ & 0.982 & 0.1603 & 0.0018 & 5.116 & 0.048 & 0.3255 & 0.0028 & 0.9228 & 0.1140 & 0.00041 & 1864 & 6.5 & 2.9 \\
\hline $9952-031.1$ & 715 & 681 & 0.952 & 206 & $2.208 \mathrm{E}-05$ & $4.818 \mathrm{E}-06$ & 0.274 & 0.2977 & 0.0046 & 5.267 & 0.045 & 0.3349 & 0.0028 & 0.9773 & 0.1141 & 0.00021 & 1865 & 3.3 & 0.2 \\
\hline $9952-063.1$ & 429 & 374 & 0.872 & 121 & $3.974 \mathrm{E}-05$ & $8.473 \mathrm{E}-06$ & 0.541 & 0.2712 & 0.0044 & 5.185 & 0.047 & 0.3280 & 0.0028 & 0.9624 & 0.1146 & 0.00028 & 1874 & 4.4 & 2.8 \\
\hline $9952-056.1$ & 699 & 385 & 0.551 & 199 & 1.184E-04 & 1.205E-05 & 2.509 & 0.1709 & 0.0028 & 5.217 & 0.045 & 0.3311 & 0.0028 & 0.9666 & 0.1143 & 0.00026 & 1868 & 4.0 & 1.5 \\
\hline $9952-048.1$ & 624 & 649 & 1.040 & 178 & $2.869 \mathrm{E}-05$ & $5.983 \mathrm{E}-06$ & 0.333 & 0.3184 & 0.0021 & 5.214 & 0.045 & 0.3310 & 0.0028 & 0.9736 & 0.1142 & 0.00023 & 1868 & 3.6 & 1.5 \\
\hline $9952-051.1$ & 398 & 142 & 0.357 & 114 & $2.794 \mathrm{E}-05$ & 7.467E-06 & 0.965 & 0.1063 & 0.0017 & 5.280 & 0.048 & 0.3336 & 0.0029 & 0.9611 & 0.1148 & 0.00029 & 1877 & 4.5 & 1.3 \\
\hline $9952-053.1$ & 646 & 515 & 0.797 & 177 & $5.183 \mathrm{E}-05$ & $9.176 \mathrm{E}-06$ & 0.775 & 0.2463 & 0.0019 & 5.028 & 0.044 & 0.3194 & 0.0027 & 0.9690 & 0.1142 & 0.00025 & 1867 & 3.9 & 4.9 \\
\hline $9952-054.1$ & 838 & 712 & 0.850 & 233 & 1.195E-04 & $1.395 \mathrm{E}-05$ & 1.695 & 0.2573 & 0.0020 & 5.072 & 0.053 & 0.3241 & 0.0033 & 0.9697 & 0.1135 & 0.00029 & 1856 & 4.6 & 2.9 \\
\hline $9952-043.1$ & 460 & 198 & 0.431 & 132 & 4.149E-05 & $8.298 \mathrm{E}-06$ & 1.175 & 0.1294 & 0.0016 & 5.271 & 0.047 & 0.3339 & 0.0029 & 0.9643 & 0.1145 & 0.00027 & 1872 & 4.3 & 0.9 \\
\hline $9952-044.1$ & 335 & 213 & 0.637 & 98 & $2.127 \mathrm{E}-05$ & $6.727 \mathrm{E}-06$ & 0.401 & 0.1960 & 0.0053 & 5.374 & 0.053 & 0.3407 & 0.0030 & 0.8890 & 0.1144 & 0.00052 & 1871 & 8.1 & -1.2 \\
\hline $9952-040.1$ & 374 & 277 & 0.741 & 107 & 4.156E-05 & 9.292E-06 & 0.674 & 0.2271 & 0.0023 & 5.253 & 0.048 & 0.3339 & 0.0029 & 0.9569 & 0.1141 & 0.00030 & 1866 & 4.8 & 0.5 \\
\hline $9952-037.1$ & 446 & 425 & 0.952 & 128 & $3.214 \mathrm{E}-05$ & 7.374E-06 & 0.408 & 0.2910 & 0.0023 & 5.283 & 0.047 & 0.3343 & 0.0029 & 0.9654 & 0.1146 & 0.00027 & 1874 & 4.2 & 0.9 \\
\hline $9952-035.1$ & 669 & 682 & 1.020 & 179 & $1.871 \mathrm{E}-05$ & 4.678E-06 & 0.219 & 0.3155 & 0.0020 & 4.915 & 0.042 & 0.3114 & 0.0026 & 0.9760 & 0.1145 & 0.00021 & 1872 & 3.4 & 7.6 \\
\hline $9952-034.1$ & 810 & 693 & 0.855 & 235 & $2.590 \mathrm{E}-06$ & 1.495E-06 & -0.037 & 0.2608 & 0.0016 & 5.340 & 0.047 & 0.3378 & 0.0028 & 0.9363 & 0.1146 & 0.00036 & 1874 & 5.6 & 0.1 \\
\hline
\end{tabular}

sample coordinates in UTM Zone 11, NAD 83

Abbreviations in brackets refers to sample location depicted in Figure 2 and in the text.

Spot name follows the convention $x-y . z$; where $x=$ sample number, $y=$ grain number and $z=$ spot number. Multiple analyses in an individual spot are labelled as $x-y . z . z$

Uncertainties reported at $1 \mathrm{~s}$ (absolute) and are calculated by numerical propagation of all known sources of error

f206 ${ }^{204}$ refers to mole fraction of total $206 \mathrm{~Pb}$ that is due to common $\mathrm{Pb}$, calculated using the 204Pb-method; common Pb composition used is the surface blank (4/6: $0.05770 ; 7 / 6$ : 0.89500 ; $8 / 6$ : 2.13840 ) refers to radiogenic $\mathrm{Pb}$ (corrected for common $\mathrm{Pb}$ )

Discordance relative to origin $=100 *(1-(206 \mathrm{~Pb} / 238 \mathrm{U}$ age $) /(207 \mathrm{~Pb} / 206 \mathrm{~Pb}$ age $))$

Calibration standard 6266; U = $910 \mathrm{ppm} ; \mathrm{Age}=559 \mathrm{Ma} ; 206 \mathrm{~Pb} / 238 \mathrm{U}=0.09059$

Error in $206 \mathrm{~Pb} / 238 \mathrm{U}$ calibration $0.8 \%$; mount calibration error $=0.16 \%$

Th/U calibration: $F=0.03900^{*} \mathrm{UO}+0.85600$ 
Table 3. Summary of key geochemical characteristics of Hottah and Great Bear igneous rocks

\begin{tabular}{|c|c|c|c|c|c|c|c|c|c|}
\hline Unit & ${ }^{1} \mathrm{Age}(\mathrm{Ma})$ & $\mathrm{La} / \mathrm{Ybcn}$ & $\mathrm{La} / \mathrm{Smcn}$ & Dy/Ybcn & $\mathrm{Eu} / \mathrm{Eu}^{*}$ & $\mathrm{Nb} / \mathrm{Y}$ & $\mathrm{Zr} / \mathrm{Y}$ & $\varepsilon \mathrm{Nd}^{\top}$ & $\mathrm{T}_{\mathrm{DM}}(\mathrm{Ga})$ \\
\hline $\begin{array}{l}\text { Sloan vesicular basalt (SBr; } \\
n=4)\end{array}$ & 1863 & $4.8-8$ & $2.8-3.7$ & $1.0-1.2$ & $0.7-0.9$ & $0.3-0.5$ & $5.3-6.8$ & - & - \\
\hline $\begin{array}{l}\text { Sloan rhyolitic crystal-rich flow } \\
(\mathrm{SBr} ; \mathrm{n}=1)\end{array}$ & 1863 & 17.9 & 5.6 & 1.2 & 0.2 & 0.5 & 4.8 & -0.5 & 2.24 \\
\hline $\begin{array}{l}\text { Faber group rhyolitic ignimbrite } \\
(\mathrm{SL} ; \mathrm{n}=1)\end{array}$ & 1869 & 14.4 & 5.4 & 1.2 & 0.5 & 0.4 & 7.8 & -1.0 & 2.31 \\
\hline $\begin{array}{l}\text { LaBine Group andesite (BLa; } \\
\mathrm{n}=1 \text { ) }\end{array}$ & 1873 & 20.6 & 7.2 & 1.1 & 0.7 & 0.5 & 9.1 & -0.6 & 2.25 \\
\hline $\begin{array}{l}\text { Grant }(R L) \text { and Rebesca }(G L) \\
\text { basalt }(n=5)\end{array}$ & 1893 & $1.8-2.7$ & $1.4-2.0$ & $1.1-1.4$ & $0.7-1.0$ & 0.1 & $2.9-3.2$ & $+1.7,+1.7$ & - \\
\hline${ }^{1}$ Bloom basalt $(n=2)$ & 1895 & 2.3 & 1.7 & $1.1-1.2$ & $1.0,1.5$ & 0.1 & 3.1 & +2.2 & - \\
\hline Grant rhyodacite (RL; $n=2$ ) & 1893 & 3.5 & 2.5 & $1.0-1.1$ & 0.6 & 0.2 & 3.8 & +0.5 & 2.41 \\
\hline${ }^{1}$ Bloom rhyodacite $(\mathrm{Br} ; \mathrm{n}=1)$ & 1895 & 5.3 & 3.6 & 1.6 & 0.4 & 0.3 & 3.0 & -1.9 & 2.50 \\
\hline $\begin{array}{l}{ }^{1} \text { Zebulon Formation rhyolite } \\
(n=6)\end{array}$ & 1906 & $1-6.7$ & $\begin{array}{l}1.4-3.6 \\
13.3-15.7\end{array}$ & $0.4-1.0$ & $0.1-0.3$ & $0.4-0.7,1.1$ & $\begin{array}{l}3.1-8.4 \\
11.1\end{array}$ & +0.8 & 2.24 \\
\hline $\begin{array}{l}{ }^{1} Z \text { Zebulon Formation basalt } \\
(n=4)\end{array}$ & 1906 & $\begin{array}{c}4.7-5.1 \\
13.2\end{array}$ & $2.2-2.4,4.2$ & $1.1-1.5$ & $0.6-0.9$ & 0.2 & $3.8-5.3$ & +2.1 & - \\
\hline Hottah tonalite $(\mathrm{Ht} ; \mathrm{n}=1)$ & 1913 & 5.3 & 2.7 & 1.1 & 1.0 & 0.3 & 3.5 & +2.0 & 2.21 \\
\hline $\begin{array}{l}\text { Hottah deformed granodiorite } \\
(\mathrm{Ht} ; \mathrm{n}=1)\end{array}$ & 1928 & - & - & - & - & - & - & -1.6 & 2.44 \\
\hline $\begin{array}{l}\text { Hottah quartz-plagioclase } \\
\text { porphyry }(H p ; n=2)\end{array}$ & 1931 & 9.3 & 4.2 & $1.0-1.2$ & 0.45 & 0.40 & $7.4,8.3$ & -1.5 & 2.44 \\
\hline $\begin{array}{l}\text { Hottah K-feldspar phenocrystic } \\
\text { granite }(\mathrm{Hg} ; \mathrm{n}=2)\end{array}$ & 1931 & $10-12.7$ & $4.8-5.6$ & 1.1 & $0.2-0.6$ & $0.4-0.6$ & $3.8-8.2$ & - & - \\
\hline
\end{tabular}

${ }^{1}$ - does not include age or geochemical data from Reichenbach (1991)

Abbreviations in brackets $(\mathrm{Ht})$ correspond to sample locations depicted in Figure 2 and in the text. Without abbreviations indicates that samples were derived from a variety of locations in the map units on Figure 2, including geochronological sample location (where applicable).

$\mathrm{n}=$ number of samples

$\mathrm{cn}=$ chondrite normalized

Full data results are presented in Tables A1 and A2; Analtical techniques are in the Appendix 


\begin{tabular}{|c|c|c|c|c|c|c|c|c|c|c|c|}
\hline Description & & & & Sloan rhyolite & Sloan basalt & Sloan basalt & Sloan basalt & Sloan basalt & $\begin{array}{l}\text { Swan Lake } \\
\text { rhyolite }\end{array}$ & $\begin{array}{l}\text { Beaverlodge } \\
\text { andesite }\end{array}$ & Bloom basalt \\
\hline Sample & & & & 10LO1144C & 10LO1144F & 10L01158A & 10LO1158C & 10LO1158D & 10LO1131B & 10VJ186A & 11LO4150A \\
\hline Age (Ma) & & & & 1863 & 1863 & 1863 & 1863 & 1863 & 1869 & 1873 & 1895 \\
\hline *UTM X & & & & 446893 & 446864 & 446779 & 446674 & 446661 & 462754 & 447400 & 434784 \\
\hline *UTM Y & & & & 7189313 & 7189461 & 7190986 & 7190991 & 7191017 & 7201067 & 7177920 & 7215381 \\
\hline Analyte & Method & Unit & MDL & & & & & & & & \\
\hline $\mathrm{SiO}_{2}$ & XRF & $\%$ & 0.1 & 74.4 & 56.8 & 57.3 & 59.7 & 57.4 & 70.5 & 60.2 & 47.9 \\
\hline $\mathrm{TiO}_{2}$ & XRF & $\%$ & 0.01 & 0.19 & 1.04 & 0.7 & 1.07 & 1.13 & 0.25 & 0.66 & 0.95 \\
\hline $\mathrm{Al}_{2} \mathrm{O}_{3}$ & XRF & $\%$ & 0.01 & 12.32 & 16.38 & 15.52 & 13.22 & 13.69 & 14.65 & 18.13 & 14.94 \\
\hline $\mathrm{Fe}_{2} \mathrm{O}_{3}$ & XRF & $\%$ & 0.01 & 2.51 & 9.41 & 9.45 & 11.02 & 11.73 & 2.86 & 5.52 & 11.75 \\
\hline $\mathrm{MnO}$ & XRF & $\%$ & 0.01 & 0.03 & 0.19 & 0.12 & 0.24 & 0.22 & 0.07 & 0.1 & 0.21 \\
\hline $\mathrm{MgO}$ & XRF & $\%$ & 0.01 & 0.1 & 3.87 & 3.83 & 4.72 & 3.95 & 0.51 & 4.27 & 7.83 \\
\hline $\mathrm{CaO}$ & XRF & $\%$ & 0.01 & 0.97 & 5.16 & 6.69 & 4.1 & 6.61 & 1.7 & 1.93 & 10.48 \\
\hline $\mathrm{Na}_{2} \mathrm{O}$ & XRF & $\%$ & 0.01 & 2.98 & 2.78 & 3.04 & 2.34 & 2.86 & 2.49 & 1.63 & 2.09 \\
\hline $\mathrm{K}_{2} \mathrm{O}$ & XRF & $\%$ & 0.01 & 5.6 & 2.72 & 1.27 & 1.55 & 1.76 & 5.87 & 5.1 & 1.21 \\
\hline $\mathrm{P}_{2} \mathrm{O}_{5}$ & $\mathrm{XRF}$ & $\%$ & 0.01 & 0.03 & 0.15 & 0.08 & 0.13 & 0.13 & 0.05 & 0.16 & 0.1 \\
\hline $\mathrm{Cr}_{2} \mathrm{O}_{3}$ & XRF & $\%$ & 0.001 & 0.003 & 0.013 & 0.005 & 0.006 & 0.005 & 0.005 & 0.009 & 0.032 \\
\hline LOI & XRF & $\%$ & & 0.91 & 1.72 & 1.99 & 2.86 & 1.29 & 1.68 & 3.14 & 2.44 \\
\hline SUM & & $\%$ & & 100.04 & 100.23 & 100 & 100.96 & 100.78 & 100.73 & 100.92 & 99.88 \\
\hline $\mathrm{Be}$ & 'ICP-MS & PPM & 1 & 114 & 3 & 4 & 6 & $<1$ & 4 & $<1$ & 1 \\
\hline V & 'ICP-MS & PPM & 8 & $<8$ & 123 & 142 & 165 & 167 & $<8$ & 75 & 237 \\
\hline Co & 'ICP-MS & PPM & 0.2 & 0.9 & 28.2 & 28.6 & 29.2 & 31.3 & 2.2 & 14.3 & 41.8 \\
\hline $\mathrm{Ni}$ & ${ }^{2} \mathrm{ICP}-\mathrm{MS}$ & PPM & 0.1 & 16.3 & 2.3 & 0.7 & 2.2 & 2.3 & 2.4 & 18.3 & 54 \\
\hline $\mathrm{Cu}$ & ¿ICP-MS & PPM & 0.1 & 0.8 & 1.1 & 0.7 & 16.8 & 1.4 & 1.4 & 0.5 & 94.8 \\
\hline $\mathrm{Zn}$ & ¿'ICP-MS & PPM & 1 & 70 & 6 & 4 & 188 & 3 & 5 & 18 & 49 \\
\hline $\mathrm{Ga}$ & ICP-ES & PPM & 0.5 & 18.1 & 21.7 & 17 & 16.7 & 17.7 & 16.9 & 22.2 & 14.3 \\
\hline As & ¿ICP-MS & PPM & 0.5 & 3.5 & 0.6 & $<0.5$ & 329 & 1.1 & 0.6 & 1.3 & $<0.5$ \\
\hline $\mathrm{Se}$ & ${ }^{4} \mathrm{ICP}-\mathrm{MS}$ & PPM & 0.5 & $<0.5$ & $<0.5$ & $<0.5$ & $<0.5$ & $<0.5$ & $<0.5$ & $<0.5$ & $<0.5$ \\
\hline $\mathrm{Rb}$ & 'ICP-MS & PPM & 0.1 & 345 & 111.5 & 49.9 & 58.1 & 59 & 221.9 & 275.7 & 33.2 \\
\hline $\mathrm{Sr}$ & 'ICP-MS & PPM & 0.5 & 33.7 & 215.5 & 254.4 & 96.9 & 141.5 & 174.8 & 230.9 & 153.3 \\
\hline Y & 'ICP-MS & PPM & 0.1 & 49.7 & 21.9 & 15.8 & 21.9 & 27.6 & 31.3 & 21 & 17.1 \\
\hline $\mathrm{Zr}$ & 'ICP-MS & PPM & 0.1 & 236.8 & 149.4 & 85.1 & 136.7 & 146.5 & 244.5 & 190.6 & 51 \\
\hline $\mathrm{Nb}$ & 'ICP-MS & PPM & 0.1 & 22.8 & 10.2 & 5.4 & 8.8 & 7.6 & 14 & 10.4 & 1.9 \\
\hline Mo & ¿ICP-MS & PPM & 0.1 & $<0.1$ & 0.4 & 0.3 & 1.3 & 0.5 & 0.3 & 0.2 & 0.1 \\
\hline $\mathrm{Cd}$ & ¿'ICP-MS & PPM & 0.1 & $<0.1$ & $<0.1$ & $<0.1$ & 0.3 & $<0.1$ & $<0.1$ & $<0.1$ & $<0.1$ \\
\hline $\mathrm{Ag}$ & ¿'ICP-MS & PPM & 0.1 & $<0.1$ & $<0.1$ & $<0.1$ & 0.2 & $<0.1$ & $<0.1$ & $<0.1$ & $<0.1$ \\
\hline Sn & 'ICP-MS & PPM & 1 & 11 & 3 & 2 & 1 & 1 & 5 & 4 & $<1$ \\
\hline $\mathrm{Sb}$ & "ICP-MS & PPM & 0.1 & 0.2 & 0.1 & 0.1 & 0.9 & 0.4 & 0.1 & 0.9 & $<0.1$ \\
\hline Cs & 'ICP-MS & PPM & 0.1 & 12.8 & 5.4 & 1.5 & 1 & 0.7 & 5.8 & 5.9 & 0.6 \\
\hline $\mathrm{Ba}$ & XRF & $\%$ & 0.01 & 0.04 & 0.05 & 0.02 & 0.04 & 0.04 & 0.11 & 0.11 & 0.01 \\
\hline $\mathrm{Ba}$ & 'ICP-MS & PPM & 1 & 251 & 483 & 229 & 322 & 302 & 995 & 1059 & 139 \\
\hline $\mathrm{La}$ & 'ICP-MS & PPM & 0.1 & 127.5 & 23.4 & 13.8 & 26.9 & 19.8 & 63.1 & 63.2 & 6 \\
\hline $\mathrm{Ce}$ & 'ICP-MS & PPM & 0.1 & 254.9 & 44.7 & 26.4 & 57.2 & 44 & 119.6 & 116.6 & 12.8 \\
\hline $\mathrm{Pr}$ & 'ICP-MS & PPM & 0.02 & 27.06 & 4.91 & 2.95 & 6.45 & 5.14 & 12.17 & 11.34 & 1.85 \\
\hline $\mathrm{Nd}$ & 'ICP-MS & PPM & 0.3 & 88 & 19 & 11.4 & 22 & 19.7 & 42.1 & 36.2 & 7.6 \\
\hline Sm & 'ICP-MS & PPM & 0.05 & 14.57 & 4.12 & 2.55 & 5 & 4.51 & 7.5 & 5.66 & 2.34 \\
\hline Eu & 'ICP-MS & PPM & 0.02 & 0.65 & 1.09 & 0.82 & 1.07 & 1.06 & 1.11 & 1.11 & 0.79 \\
\hline Gd & 'ICP-MS & PPM & 0.05 & 11.69 & 4.14 & 2.86 & 4.54 & 4.88 & 6.15 & 4.5 & 2.67 \\
\hline $\mathrm{Tb}$ & 'ICP-MS & PPM & 0.01 & 1.77 & 0.7 & 0.48 & 0.73 & 0.83 & 0.99 & 0.77 & 0.49 \\
\hline Dy & 'ICP-MS & PPM & 0.05 & 9.18 & 3.76 & 2.66 & 3.65 & 4.88 & 5.43 & 3.73 & 3.03 \\
\hline Ho & 'ICP-MS & PPM & 0.02 & 1.85 & 0.87 & 0.65 & 0.78 & 1.08 & 1.05 & 0.85 & 0.72 \\
\hline $\mathrm{Er}$ & 'ICP-MS & PPM & 0.03 & 5.27 & 2.5 & 1.8 & 2.29 & 3.26 & 3.22 & 2.54 & 2.11 \\
\hline Tm & 'ICP-MS & PPM & 0.01 & 0.73 & 0.33 & 0.23 & 0.34 & 0.44 & 0.51 & 0.34 & 0.29 \\
\hline $\mathrm{Yb}$ & 'ICP-MS & PPM & 0.05 & 5.1 & 2.1 & 1.83 & 2.17 & 2.94 & 3.15 & 2.2 & 1.87 \\
\hline Lu & 'ICP-MS & PPM & 0.01 & 0.79 & 0.33 & 0.24 & 0.4 & 0.47 & 0.55 & 0.38 & 0.31 \\
\hline $\mathrm{Hf}$ & 'ICP-MS & PPM & 0.1 & 7.5 & 4 & 2.5 & 3.8 & 4.1 & 7.3 & 5.3 & 1.5 \\
\hline Ta & 'ICP-MS & PPM & 0.1 & 1.6 & 1 & 0.6 & 0.6 & 0.6 & 1.3 & 1.1 & 0.2 \\
\hline W & 'ICP-MS & PPM & 0.5 & 3.6 & $<0.5$ & 1 & 1.3 & 1.6 & 1.1 & 2.3 & $<0.5$ \\
\hline $\mathrm{Au}$ & ${ }^{2} \mathrm{ICP}-\mathrm{MS}$ & PPB & 0.5 & 1 & 1.3 & 1.2 & 3.9 & 1.3 & $<0.5$ & $<0.5$ & $<0.5$ \\
\hline $\mathrm{Hg}$ & "CP-MS & PPM & 0.01 & $<0.01$ & $<0.01$ & $<0.01$ & $<0.01$ & $<0.01$ & $<0.01$ & $<0.01$ & $<0.01$ \\
\hline TI & ${ }^{ } \mathrm{ICP}-\mathrm{MS}$ & PPM & 0.1 & 0.1 & $<0.1$ & $<0.1$ & 0.5 & $<0.1$ & $<0.1$ & $<0.1$ & $<0.1$ \\
\hline $\mathrm{Pb}$ & ${ }^{2} \mathrm{ICP}-\mathrm{MS}$ & PPM & 0.1 & 3.9 & 1.2 & 1.3 & 157.5 & 1.9 & 0.7 & 0.9 & 2.1 \\
\hline $\mathrm{Bi}$ & ¿ICP-MS & PPM & 0.1 & 0.2 & $<0.1$ & $<0.1$ & $<0.1$ & $<0.1$ & 0.1 & 0.3 & $<0.1$ \\
\hline Th & 'ICP-MS & PPM & 0.2 & 37 & 7.5 & 3.9 & 7.9 & 8.4 & 28.1 & 30 & 0.5 \\
\hline$U$ & 'ICP-MS & PPM & 0.1 & 8 & 3.5 & 2 & 2 & 2.3 & 8.8 & 3.4 & 0.1 \\
\hline \multirow{2}{*}{\multicolumn{12}{|c|}{$\begin{array}{l}\text { Notes: } \\
\text { *UTM Zone 11, NAD } 83\end{array}$}} \\
\hline & & & & & & & & & & & \\
\hline MDL-Mini & n detection & & & & & & & & & & \\
\hline 1 - Fusion IC & P-MS & & & & & & & & & & \\
\hline 2- Aqua $\mathrm{Re}$ & 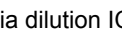 & & & & & & & & & & \\
\hline
\end{tabular}




\begin{tabular}{|c|c|c|c|c|c|c|c|c|c|}
\hline Bloom basalt & $\begin{array}{l}\text { Bloom rhyo- } \\
\text { dacite }\end{array}$ & $\begin{array}{c}\text { Rebesca } \\
\text { basalt }\end{array}$ & $\begin{array}{c}\text { Rebesca } \\
\text { basalt }\end{array}$ & $\begin{array}{c}\text { Rebesca } \\
\text { basalt }\end{array}$ & Grant basalt & Grant basalt & $\begin{array}{l}\text { Grant rhyo- } \\
\text { dacite }\end{array}$ & $\begin{array}{l}\text { Grant rhyo- } \\
\text { dacite }\end{array}$ & $\begin{array}{l}\text { Zebulon } \\
\text { rhyolite }\end{array}$ \\
\hline 11LO4152A & 11LO4153A & $11 \mathrm{MH} 8014 \mathrm{~A}$ & $11 \mathrm{MH} 8015 \mathrm{~A}$ & 11LO4034A & 11VJ9213A & 11VJ9213B & HY.F 361.80 & HY.F 362.80 & 10LO1114 \\
\hline 1895 & 1895 & 1895 & 1895 & 1895 & 1895 & 1895 & 1895 & 1895 & 1905 \\
\hline 436767 & 435077 & 522522 & 522028 & 522021 & 519038 & 519028 & 520440 & 520718 & 438720 \\
\hline 7222049 & 7222942 & 7161224 & 7160913 & 7160853 & 7206068 & 7206070 & 7207824 & 7208224 & 7175363 \\
\hline 46.8 & 78.8 & 49.5 & 49.7 & 49.2 & 49.6 & 49.4 & 69.5 & 77.1 & 75 \\
\hline 1.06 & 0.24 & 1.45 & 1.42 & 1.48 & 1.77 & 1.78 & 0.24 & 0.24 & 0.1 \\
\hline 16.02 & 10.23 & 13.21 & 13.54 & 13.36 & 12.8 & 12.89 & 10.03 & 10.71 & 11.82 \\
\hline 12.07 & 2.68 & 14.77 & 14.36 & 15.69 & 14.45 & 14.77 & 2.62 & 3.12 & 4 \\
\hline 0.2 & 0.03 & 0.22 & 0.24 & 0.21 & 0.22 & 0.23 & 0.12 & 0.04 & 0.01 \\
\hline 6.22 & 0.89 & 6.48 & 4.87 & 6.26 & 6.06 & 6.14 & 0.87 & 1.4 & 0.66 \\
\hline 12.33 & 0.36 & 9.99 & 11.75 & 11.24 & 9.32 & 9.89 & 6.58 & 0.98 & 0.01 \\
\hline 1.6 & 0.71 & 2.17 & 3.2 & 2.29 & 2.59 & 3.27 & 2.64 & 2.97 & 0.07 \\
\hline 1.56 & 5.01 & 0.94 & 0.53 & 0.27 & 0.46 & 0.25 & 2.35 & 2.54 & 8.06 \\
\hline 0.11 & 0.15 & 0.12 & 0.12 & 0.12 & 0.16 & 0.16 & $<0.01$ & 0.01 & 0.01 \\
\hline 0.021 & 0.005 & 0.016 & 0.026 & 0.028 & 0.022 & 0.023 & 0.008 & 0.002 & 0.005 \\
\hline 1.61 & 0.94 & 0.78 & 0.28 & -0.04 & 1.76 & 2.03 & 5.88 & 1.2 & 0.99 \\
\hline 99.58 & 100.13 & 99.61 & 100.05 & 100.05 & 99.24 & 100.77 & 100.9 & 100.38 & 100.76 \\
\hline$<1$ & 2 & $<1$ & 2 & $<1$ & 2 & 1 & 4 & 3 & 3 \\
\hline 267 & 16 & 319 & 304 & 324 & 366 & 330 & $<8$ & $<8$ & $<8$ \\
\hline 42.5 & 2.8 & 47.8 & 46.2 & 48.8 & 45.5 & 41.3 & 11.6 & 23.1 & 2.3 \\
\hline 24.2 & 5.5 & 22.5 & 20.2 & 27.2 & 21.9 & 26.3 & 0.3 & 1 & 1.6 \\
\hline 88.6 & 14 & 48 & 25.7 & 83 & 44.6 & 71.4 & 3 & 1.3 & 1.2 \\
\hline 17 & 27 & 41 & 28 & 19 & 64 & 69 & 116 & 173 & 14 \\
\hline 16.3 & 11.9 & 17.1 & 16.4 & 17 & 16.9 & 16.4 & 22.7 & 21.7 & 18 \\
\hline$<0.5$ & 3.1 & $<0.5$ & 0.7 & 1.1 & $<0.5$ & $<0.5$ & $<0.5$ & $<0.5$ & $<0.5$ \\
\hline$<0.5$ & $<0.5$ & $<0.5$ & $<0.5$ & $<0.5$ & $<0.5$ & $<0.5$ & $<0.5$ & $<0.5$ & $<0.5$ \\
\hline 39.5 & 150.9 & 27.1 & 12.1 & 7.8 & 12.4 & 5.1 & 137.8 & 77.1 & 170.5 \\
\hline 221.7 & 31.7 & 88.4 & 134.4 & 115.7 & 132 & 119.3 & 164.1 & 151.5 & 12 \\
\hline 19.8 & 34 & 28.3 & 30 & 30.7 & 39.5 & 35.6 & 125.6 & 84.9 & 28.1 \\
\hline 61.3 & 103.3 & 81.3 & 89.5 & 87.9 & 124.6 & 109.2 & 356.8 & 398.6 & 237.2 \\
\hline 1.9 & 11.6 & 3.5 & 3.7 & 3.2 & 5.7 & 4.5 & 22.4 & 20.7 & 18.9 \\
\hline 0.2 & 0.7 & 0.2 & 0.2 & 0.2 & 0.3 & 0.2 & 0.4 & 1.6 & 0.7 \\
\hline$<0.1$ & $<0.1$ & $<0.1$ & $<0.1$ & $<0.1$ & $<0.1$ & $<0.1$ & 0.2 & 0.4 & $<0.1$ \\
\hline$<0.1$ & $<0.1$ & $<0.1$ & $<0.1$ & $<0.1$ & $<0.1$ & $<0.1$ & $<0.1$ & $<0.1$ & $<0.1$ \\
\hline$<1$ & 4 & 1 & $<1$ & $<1$ & $<1$ & $<1$ & 6 & 7 & 2 \\
\hline 0.2 & 0.3 & $<0.1$ & $<0.1$ & $<0.1$ & $<0.1$ & $<0.1$ & 0.2 & $<0.1$ & 0.2 \\
\hline 1.6 & 5.9 & 4.5 & 0.4 & 0.9 & 0.4 & 0.2 & 1.6 & 0.7 & 1.9 \\
\hline 0.03 & 0.09 & $<0.01$ & 0.01 & $<0.01$ & 0.01 & $<0.01$ & 0.05 & 0.05 & 0.03 \\
\hline 321 & 836 & 97 & 125 & 49 & 117 & 64 & 433 & 491 & 293 \\
\hline 6.8 & 42.3 & 10.5 & 8.6 & 8 & 12 & 12.1 & 56.3 & 51.4 & 35.7 \\
\hline 16 & 84.2 & 21.2 & 20.3 & 18.5 & 29.6 & 25.8 & 119.4 & 108.3 & 88.4 \\
\hline 2.31 & 9.92 & 2.76 & 2.84 & 2.82 & 3.72 & 3.58 & 15.15 & 13.83 & 9.56 \\
\hline 10.8 & 34.8 & 13.5 & 14.1 & 12.2 & 15.8 & 16.1 & 62.6 & 56.5 & 34.9 \\
\hline 2.78 & 7.54 & 3.46 & 3.51 & 3.69 & 5.04 & 4.53 & 14.95 & 13.09 & 6.36 \\
\hline 1.45 & 0.95 & 1.12 & 1.23 & 1.23 & 1.36 & 1.58 & 2.82 & 3.11 & 0.14 \\
\hline 3.1 & 6.9 & 4.11 & 4.6 & 4.78 & 6.16 & 5.31 & 16.63 & 13.66 & 4.69 \\
\hline 0.58 & 1.11 & 0.78 & 0.82 & 0.85 & 1.08 & 0.96 & 3.2 & 2.53 & 0.88 \\
\hline 4.03 & 6.51 & 5.21 & 5.44 & 5.37 & 6.75 & 5.91 & 19.74 & 15.98 & 5.49 \\
\hline 0.79 & 1.1 & 1.05 & 1.07 & 1.16 & 1.03 & 1.3 & 4.4 & 3.36 & 1.13 \\
\hline 2.6 & 3.02 & 3.21 & 3.44 & 3.61 & 4.73 & 3.92 & 13.52 & 9.86 & 3.27 \\
\hline 0.34 & 0.5 & 0.49 & 0.5 & 0.52 & 0.66 & 0.58 & 2.03 & 1.47 & 0.57 \\
\hline 2.21 & 2.67 & 2.95 & 3.13 & 3.18 & 3.19 & 3.65 & 13.67 & 9.32 & 3.81 \\
\hline 0.3 & 0.37 & 0.48 & 0.5 & 0.49 & 0.59 & 0.55 & 2.06 & 1.43 & 0.64 \\
\hline 1.6 & 3.9 & 2.7 & 3 & 2.7 & 3 & 3.4 & 10.3 & 11.7 & 7.3 \\
\hline 0.1 & 1 & 0.3 & 0.3 & 0.3 & 0.6 & 0.4 & 1.7 & 1.9 & 1.5 \\
\hline$<0.5$ & 3.2 & $<0.5$ & 0.9 & $<0.5$ & 0.8 & $<0.5$ & 101.6 & 202.7 & 0.8 \\
\hline$<0.5$ & $<0.5$ & 1.3 & 0.9 & $<0.5$ & $<0.5$ & $<0.5$ & 3.8 & 2.5 & $<0.5$ \\
\hline$<0.01$ & $<0.01$ & $<0.01$ & $<0.01$ & $<0.01$ & $<0.01$ & $<0.01$ & $<0.01$ & $<0.01$ & $<0.01$ \\
\hline 0.1 & 0.4 & 0.2 & $<0.1$ & $<0.1$ & $<0.1$ & $<0.1$ & $<0.1$ & $<0.1$ & $<0.1$ \\
\hline 2.8 & 7.9 & 1.5 & 0.9 & 0.8 & 2.5 & 1.7 & 15.2 & 26.6 & 2.4 \\
\hline$<0.1$ & 0.5 & 0.1 & $<0.1$ & $<0.1$ & $<0.1$ & $<0.1$ & 0.2 & 0.2 & 0.1 \\
\hline 1 & 10.8 & 1.8 & 1.4 & 1.2 & 3.2 & 2.8 & 16.7 & 16.4 & 14.4 \\
\hline 0.1 & 4.1 & 0.5 & 0.5 & 0.4 & 0.7 & 0.8 & 4.6 & 4.2 & 3.6 \\
\hline
\end{tabular}




\begin{tabular}{|c|c|c|c|c|c|c|c|c|c|c|}
\hline $\begin{array}{l}\text { Zebulon } \\
\text { rhyolite }\end{array}$ & $\begin{array}{l}\text { Zebulon } \\
\text { rhyolite }\end{array}$ & $\begin{array}{l}\text { Zebulon } \\
\text { rhyolite }\end{array}$ & $\begin{array}{l}\text { Zebulon } \\
\text { rhyolite }\end{array}$ & $\begin{array}{l}\text { Zebulon } \\
\text { rhyolite }\end{array}$ & $\begin{array}{c}\text { Zebulon } \\
\text { basalt }\end{array}$ & $\begin{array}{c}\text { Zebulon } \\
\text { basalt }\end{array}$ & $\begin{array}{l}\text { Zebulon } \\
\text { basalt }\end{array}$ & $\begin{array}{c}\text { Zebulon } \\
\text { basalt }\end{array}$ & $\begin{array}{l}\text { Hottah } \\
\text { tonalite }\end{array}$ & $\begin{array}{c}\text { Hottah } \\
\text { granodiorite }\end{array}$ \\
\hline 10LO1116A & 10LO1116B & 10РА33А & 10VJ89A & 11VJ9221D & 09L09040 & 10VJ89B & 11VJ9221A & 11VJ9221B & 11LO4157A & $11 \mathrm{LO} 4156 \mathrm{~A}$ \\
\hline 1905 & 1905 & 1905 & 1905 & 1905 & 1905 & 1905 & 1905 & 1905 & 1913 & 1930 \\
\hline 437934 & 437911 & 437191 & 439110 & 431138 & 443234 & 439327 & 431094 & 431055 & 435738 & 452888 \\
\hline 7174560 & 7174557 & 7208164 & 7208252 & 7205432 & 7178978 & 7208329 & 7205519 & 7205589 & 7206954 & 7208252 \\
\hline 75.5 & 74.4 & 77.7 & 84 & 74.3 & 49.2 & 62.4 & 53.1 & 48.6 & 56.8 & 68.7 \\
\hline 0.13 & 0.11 & 0.03 & 0.08 & 0.1 & 1.07 & 0.53 & 1.36 & 1.61 & 0.67 & 0.74 \\
\hline 11.68 & 12.69 & 10.37 & 7.91 & 12.39 & 18.8 & 15.24 & 18.21 & 14.64 & 16.99 & 13.53 \\
\hline 3.4 & 3.46 & 2.18 & 2.72 & 2.24 & 16.01 & 10.81 & 12.38 & 13.87 & 7.89 & 5.75 \\
\hline$<0.01$ & 0.02 & $<0.01$ & $<0.01$ & $<0.01$ & 0.03 & 0.02 & 0.03 & 0.37 & 0.15 & 0.09 \\
\hline 0.53 & 0.72 & 0.03 & 0.36 & 0.03 & 3.85 & 0.83 & 0.7 & 5.35 & 4.17 & 2.04 \\
\hline 0.01 & 0.03 & 0.02 & 0.01 & 0.02 & 0.38 & 0.13 & 0.68 & 8.08 & 5.43 & 1.17 \\
\hline 0.06 & 0.06 & 0.12 & 0.09 & 0.1 & 0.14 & 0.23 & 2.14 & 2.38 & 4.05 & 3.09 \\
\hline 7.7 & 7.68 & 8.9 & 4.05 & 11.13 & 6.58 & 9.01 & 9.67 & 1.09 & 2.07 & 3.59 \\
\hline$<0.01$ & $<0.01$ & $<0.01$ & $<0.01$ & $<0.01$ & 0.22 & 0.1 & 0.45 & 0.32 & 0.09 & 0.16 \\
\hline 0.002 & 0.005 & $<0.001$ & $<0.001$ & 0.003 & 0.029 & 0.035 & $<0.001$ & 0.03 & 0.005 & 0.003 \\
\hline 1.07 & 1.34 & 0.22 & 0.93 & 0.19 & 3.8 & 1.5 & 1.52 & 3.33 & 1.68 & 1.37 \\
\hline 100.17 & 100.57 & 99.7 & 100.27 & 100.54 & 100.15 & 100.89 & 100.28 & 99.68 & 100.04 & 100.38 \\
\hline 5 & 2 & 3 & 5 & $<1$ & 5 & 2 & 3 & 1 & 1 & 2 \\
\hline$<8$ & $<8$ & $<8$ & $<8$ & $<8$ & 114 & 68 & 85 & 240 & 117 & 30 \\
\hline 1.1 & 2.8 & 0.6 & 0.4 & 0.9 & 22.1 & 4.1 & 7.1 & 42 & 17.7 & 6.8 \\
\hline 1.7 & 4.8 & 43.4 & 25.7 & 1.4 & 80.8 & 6 & 1.5 & 67 & 19.3 & 6.2 \\
\hline 5.8 & 5.5 & 20.5 & 9 & 1.2 & 0.2 & 11.1 & 0.5 & 13.7 & 9.8 & 3.9 \\
\hline 42 & 55 & 80 & 35 & 2 & 20 & 108 & 7 & 97 & 56 & 61 \\
\hline 13.4 & 19.2 & 13.4 & 18.4 & 7.7 & 22 & 21 & 20.3 & 18.8 & 17.2 & 19.4 \\
\hline 2.5 & 0.7 & 1.2 & 1.3 & 1.4 & 1 & 1 & 3.6 & 1.8 & $<0.5$ & 0.7 \\
\hline 0.6 & $<0.5$ & $<0.5$ & $<0.5$ & $<0.5$ & $<0.5$ & $<0.5$ & $<0.5$ & $<0.5$ & $<0.5$ & $<0.5$ \\
\hline 173.4 & 199.4 & 211.5 & 215.1 & 230.5 & 256 & 357.5 & 340.8 & 32.5 & 47.8 & 118.7 \\
\hline 6.3 & 8.7 & 15.8 & 15.4 & 15.4 & 7.5 & 19 & 28.8 & 376.8 & 332.3 & 87.8 \\
\hline 19 & 20.7 & 33.3 & 58.2 & 31.8 & 23.6 & 23.1 & 35.8 & 32 & 19.7 & 40.6 \\
\hline 211.1 & 232.5 & 157.4 & 179.9 & 204.5 & 88.7 & 109 & 190.1 & 154.3 & 69.8 & 337.7 \\
\hline 22.3 & 23.7 & 23.9 & 23.4 & 18.9 & 4.9 & 5.3 & 8.4 & 6.1 & 5.1 & 19.1 \\
\hline 0.9 & 1.9 & 0.3 & 0.5 & 0.3 & $<0.1$ & 0.3 & 0.6 & 0.2 & $<0.1$ & 1 \\
\hline$<0.1$ & $<0.1$ & $<0.1$ & $<0.1$ & $<0.1$ & $<0.1$ & $<0.1$ & $<0.1$ & $<0.1$ & $<0.1$ & $<0.1$ \\
\hline$<0.1$ & $<0.1$ & $<0.1$ & $<0.1$ & $<0.1$ & $<0.1$ & $<0.1$ & $<0.1$ & $<0.1$ & $<0.1$ & $<0.1$ \\
\hline 4 & 4 & 3 & 3 & 2 & 1 & 2 & 2 & 1 & 1 & 6 \\
\hline 0.3 & 0.3 & 0.3 & 0.8 & 0.3 & 0.1 & 0.3 & 1.4 & $<0.1$ & $<0.1$ & $<0.1$ \\
\hline 1.9 & 2.8 & 0.8 & 1 & 1.2 & 5.8 & 5.9 & 6.3 & 0.5 & 0.8 & 1.1 \\
\hline 0.02 & 0.03 & 0.09 & 0.04 & 0.03 & 0.07 & 0.1 & 0.04 & 0.04 & 0.05 & 0.09 \\
\hline 223 & 249 & 908 & 840 & 327 & 694 & 875 & 384 & 288 & 485 & 785 \\
\hline 39.4 & 24.8 & 6.9 & 20.9 & 6.6 & 18.4 & 42 & 24.5 & 21.3 & 15.9 & 61.4 \\
\hline 76.1 & 44 & 18.3 & 53 & 14.9 & 41.4 & 72.8 & 61.5 & 49.3 & 39.1 & 125.7 \\
\hline 7.52 & 3.9 & 2.43 & 7.07 & 2.17 & 5.14 & 9.39 & 8.05 & 6.8 & 4.86 & 14.36 \\
\hline 21.2 & 11 & 9.5 & 26.4 & 8.6 & 20.9 & 32.5 & 34.5 & 30.1 & 18.3 & 51.3 \\
\hline 1.91 & 1.06 & 3.11 & 7.88 & 2.4 & 4.94 & 6.51 & 7.14 & 6.28 & 3.8 & 9.15 \\
\hline 0.09 & 0.08 & 0.11 & 0.34 & 0.27 & 1.45 & 1.17 & 1.67 & 1.77 & 1.17 & 1.4 \\
\hline 1.3 & 1.29 & 3.68 & 8.33 & 3.07 & 4.77 & 5.32 & 7.38 & 6.08 & 3.72 & 8.82 \\
\hline 0.35 & 0.33 & 0.85 & 1.61 & 0.71 & 0.83 & 0.74 & 1.2 & 0.96 & 0.56 & 1.34 \\
\hline 2.75 & 3.27 & 4.98 & 9.73 & 5.45 & 4.68 & 3.69 & 7.28 & 6.01 & 3.42 & 8.09 \\
\hline 0.76 & 0.9 & 1.35 & 2.13 & 1.19 & 1 & 0.76 & 1.38 & 1.21 & 0.69 & 1.51 \\
\hline 3.01 & 3.41 & 3.87 & 6.26 & 3.89 & 2.6 & 2.32 & 3.77 & 3.47 & 2.18 & 4.09 \\
\hline 0.53 & 0.55 & 0.61 & 0.93 & 0.65 & 0.36 & 0.32 & 0.55 & 0.52 & 0.33 & 0.66 \\
\hline 4.31 & 4.47 & 4.89 & 6.4 & 4.63 & 2.59 & 2.28 & 3.28 & 3.25 & 2.15 & 3.81 \\
\hline 0.68 & 0.74 & 0.78 & 0.96 & 0.69 & 0.41 & 0.36 & 0.43 & 0.46 & 0.31 & 0.55 \\
\hline 7.5 & 8.9 & 7.1 & 8.1 & 7.8 & 2.6 & 3.1 & 4.8 & 4.4 & 2.2 & 10.2 \\
\hline 1.7 & 1.8 & 2 & 2 & 1.4 & 0.4 & 0.5 & 0.6 & 0.4 & 0.4 & 1.5 \\
\hline 1.3 & 0.9 & 4 & 3.8 & 0.8 & $<0.5$ & 3.5 & 0.8 & $<0.5$ & $<0.5$ & 1.9 \\
\hline$<0.5$ & 0.9 & 0.8 & $<0.5$ & 1.5 & $<0.5$ & $<0.5$ & 0.7 & $<0.5$ & $<0.5$ & $<0.5$ \\
\hline$<0.01$ & $<0.01$ & $<0.01$ & $<0.01$ & $<0.01$ & $<0.01$ & $<0.01$ & $<0.01$ & $<0.01$ & $<0.01$ & $<0.01$ \\
\hline 0.1 & $<0.1$ & 0.5 & $<0.1$ & $<0.1$ & 0.2 & $<0.1$ & $<0.1$ & $<0.1$ & $<0.1$ & 0.2 \\
\hline 12.7 & 2.6 & 2.2 & 1.7 & 1 & 2.1 & 5 & 3.4 & 1.3 & 8.1 & 8.9 \\
\hline 0.3 & $<0.1$ & $<0.1$ & $<0.1$ & $<0.1$ & 0.3 & 0.2 & 0.3 & $<0.1$ & $<0.1$ & 0.1 \\
\hline 14.9 & 15.6 & 17.3 & 19.3 & 13 & 2.9 & 4.6 & 2.5 & 2 & 1.8 & 26.6 \\
\hline 4.8 & 4.6 & 3.2 & 4.6 & 3.3 & 2.2 & 2.6 & 1.6 & 0.8 & 0.5 & 6.6 \\
\hline
\end{tabular}




\begin{tabular}{|c|c|c|c|}
\hline $\begin{array}{l}\text { Hottah } \\
\text { porphyry }\end{array}$ & $\begin{array}{l}\text { Hottah } \\
\text { porphyry }\end{array}$ & Hottah granite & Hottah granite \\
\hline 06LO-BLL2 & 09L09039A & 09L09078A & 09LO9026 \\
\hline 1930 & 1930 & 1930 & 1930 \\
\hline 443065 & 443456 & 442095 & 440933 \\
\hline 7178527 & 7179171 & 7177812 & 7177258 \\
\hline 68.9 & 70.1 & 71.9 & 77.2 \\
\hline 0.62 & 0.59 & 0.44 & 0.22 \\
\hline 13.74 & 13.22 & 12.96 & 11.43 \\
\hline 5.26 & 4.99 & 4.13 & 2.43 \\
\hline 0.06 & 0.04 & 0.03 & 0.01 \\
\hline 1.01 & 1.75 & 1.31 & 0.74 \\
\hline 1.39 & 0.33 & 0.2 & 0.11 \\
\hline 3.09 & 2.7 & 2.25 & 0.09 \\
\hline 4.4 & 4.51 & 5.91 & 6.56 \\
\hline 0.15 & 0.13 & 0.09 & 0.08 \\
\hline 0.003 & 0.003 & 0.006 & 0.007 \\
\hline 1.01 & 1.63 & 1.24 & 1.36 \\
\hline 99.75 & 100.1 & 100.58 & 100.25 \\
\hline 3 & 2 & 5 & 2 \\
\hline 36 & 23 & 32 & 10 \\
\hline 6.5 & 5.5 & 4.2 & 1.1 \\
\hline 4.8 & 4.3 & 5 & 5 \\
\hline 12.1 & 3.4 & 2 & 2.6 \\
\hline 50 & 56 & 33 & 17 \\
\hline 20.9 & 17.8 & 18.6 & 16.5 \\
\hline 0.8 & $<0.5$ & 0.9 & 0.6 \\
\hline$<0.5$ & $<0.5$ & $<0.5$ & $<0.5$ \\
\hline 131.2 & 125.7 & 204.7 & 294.9 \\
\hline 107.1 & 46.8 & 38.7 & 20.7 \\
\hline 50.2 & 42.5 & 37.4 & 43.3 \\
\hline 373.3 & 351.8 & 269.5 & 163.8 \\
\hline 21.1 & 18.3 & 20.2 & 17.1 \\
\hline 1.9 & 0.2 & 0.4 & 0.4 \\
\hline$<0.1$ & $<0.1$ & $<0.1$ & 0.1 \\
\hline$<0.1$ & $<0.1$ & $<0.1$ & $<0.1$ \\
\hline 6 & 7 & 8 & 10 \\
\hline 0.2 & 0.8 & $<0.1$ & $<0.1$ \\
\hline 2.4 & 1.3 & 2.4 & 18 \\
\hline 0.1 & 0.09 & 0.08 & 0.04 \\
\hline 973 & 770 & 717 & 371 \\
\hline 64.5 & 64.3 & 54.2 & 62.3 \\
\hline 132.3 & 126.9 & 111.3 & 126.3 \\
\hline 15.31 & 13.67 & 12.4 & 13.3 \\
\hline 57.3 & 47.4 & 41 & 43 \\
\hline 10.25 & 9.58 & 7.25 & 8.26 \\
\hline 1.57 & 1.28 & 0.9 & 0.57 \\
\hline 9.62 & 8.48 & 6.39 & 7.35 \\
\hline 1.49 & 1.41 & 1.07 & 1.21 \\
\hline 8.73 & 7.71 & 6.47 & 6.83 \\
\hline 1.81 & 1.61 & 1.29 & 1.5 \\
\hline 5.25 & 4.56 & 4.03 & 4.48 \\
\hline 0.79 & 0.66 & 0.58 & 0.66 \\
\hline 4.91 & 5.01 & 3.89 & 4.29 \\
\hline 0.72 & 0.69 & 0.58 & 0.67 \\
\hline 11 & 10.6 & 8.6 & 5.8 \\
\hline 1.7 & 1.7 & 1.7 & 2 \\
\hline 2 & 1.2 & 2.1 & 1.8 \\
\hline 4.3 & 1.5 & 2.7 & $<0.5$ \\
\hline$<0.01$ & $<0.01$ & $<0.01$ & $<0.01$ \\
\hline 0.1 & $<0.1$ & $<0.1$ & $<0.1$ \\
\hline 7.5 & 4.9 & 4.9 & 7.6 \\
\hline 0.6 & 0.2 & 0.2 & 0.1 \\
\hline 27.5 & 27.9 & 37.2 & 47.9 \\
\hline 7.7 & 8.2 & 8.1 & 11 \\
\hline
\end{tabular}


Table A2: Sm-Nd isotope data

\begin{tabular}{|c|c|c|c|c|c|c|c|c|c|c|}
\hline Description & Sample Name & Age & $\mathrm{Nd}(\mathrm{ppm})$ & Sm (ppm) & $\begin{array}{l}{ }^{143} \mathrm{Nd} / /^{144} \mathrm{Nd} \\
\text { (current) }\end{array}$ & ${ }^{147} \mathrm{Sm} /{ }^{144} \mathrm{Nd}$ & $\begin{array}{l}{ }^{143} \mathrm{Nd} / /^{144} \mathrm{Nd} \\
\text { (initial) }\end{array}$ & $+/-(2 \sigma)$ & $\varepsilon \mathrm{Nd}_{(\mathrm{CHUR})}{ }^{\top}$ & $\begin{array}{c}\mathrm{T}_{\mathrm{DM}} \\
(0.214,0.513115)\end{array}$ \\
\hline Stairs Bay rhyolite (SBr) & 10lo1144c & 1862 & 98.86 & 16.00 & 0.511403 & 0.0978 & 0.510205 & 0.000016 & -0.5 & 2236 \\
\hline Stairs Bay basalt (SBr) & $10 l o 1144 f$ & 1862 & 21.16 & 4.55 & 0.511840 & 0.1299 & 0.510249 & 0.000019 & 0.4 & - \\
\hline $\begin{array}{l}\text { Great Bear hornblende granodiorite } \\
\text { (ZR) }\end{array}$ & $11 / 04155 a$ & 1869 & 47.55 & 8.96 & 0.511480 & 0.1139 & 0.510079 & 0.000034 & -2.7 & 2478 \\
\hline Swan Lake ignimbrite (SL) & 10lo1131b & 1869 & 43.66 & 7.67 & 0.511474 & 0.1062 & 0.510168 & 0.000016 & -1.0 & 2310 \\
\hline Beaverlodge andesite (BLa) & 10vj186 & 1873 & 29.71 & 4.71 & 0.511366 & 0.0959 & 0.510184 & 0.000015 & -0.6 & 2248 \\
\hline Bloom rhyodacite $(\mathrm{Br})$ & 11lo4153a & 1895 & 39.14 & 8.13 & 0.511656 & 0.1255 & 0.510091 & 0.000038 & -1.8 & 2500 \\
\hline Bloom basalt & 11lo4150a & 1895 & 9.53 & 2.61 & 0.512362 & 0.1654 & 0.510300 & 0.000023 & 2.3 & - \\
\hline Grant basalt (GL) & $11 v j 9213 a$ & 1893 & 17.50 & 4.95 & 0.512406 & 0.1711 & 0.510275 & 0.000024 & 1.7 & - \\
\hline Grant rhyodacite (GL) & 362.8 & 1893 & 59.08 & 14.24 & 0.512028 & 0.1457 & 0.510213 & 0.000021 & 0.5 & 2413 \\
\hline Rebesca basalt (RL) & 11lo4034a & 1893 & 12.79 & 3.82 & 0.512524 & 0.1804 & 0.510276 & 0.000025 & 1.7 & - \\
\hline Zebulon rhyolite (Zr) & 10101114 & 1906 & 36.50 & 6.77 & 0.511617 & 0.1121 & 0.510211 & 0.000017 & 0.8 & 2232 \\
\hline Zebulon basalt & 09109040 & 1906 & 23.68 & 5.26 & 0.511962 & 0.1342 & 0.510278 & 0.000020 & 2.1 & - \\
\hline Hottah tonalite $(\mathrm{Ht})$ & $11 l o 4157 a$ & 1910 & 18.94 & 4.07 & 0.511891 & 0.1298 & 0.510259 & 0.000039 & 1.8 & 2208 \\
\hline Hottah granodiorite $(\mathbf{H g})$ & $11 l o 4156 a$ & 1930 & 54.05 & 10.17 & 0.511503 & 0.1137 & 0.510059 & 0.000034 & -1.6 & 2438 \\
\hline Hottah porphyry (Hp) & 09lo9039a & 1930 & 53.34 & 10.10 & 0.511517 & 0.1145 & 0.510063 & 0.000018 & -1.5 & 2436 \\
\hline
\end{tabular}

Notes: $T_{\mathrm{DM}}$ calculated using Goldstein et al. (1984) for samples with ${ }^{147} \mathrm{Sm} /{ }^{144} \mathrm{Nd}<0.1500$

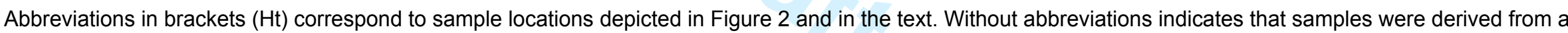
variety of locations in the map units on Figure 2, including geochronological sample location (where applicable). 